\title{
EL PRIMER LARGOMETRAJE DE ANIMACIÓN EUROPEO EN COLOR: GARBANCITO DE LA MANCHA (1945). ANÁLISIS DE LA MÚSICA DE JACINTO GUERRERO ${ }^{1}$
}

\author{
THE FIRST EUROPEAN CARTOONS' FILM: THE KNIGHT \\ GARBANCITO (1945). AN ANALYSIS OF THE MUSIC \\ BY JACINTO GUERRERO
}

\author{
María José Ramos Machí \\ Universidad Politécnica de Valencia
}

\section{Resumen:}

El presente artículo se aproxima por primera vez, desde una vertiente específicamente musical, al análisis y estudio de la película Garbancito de la Mancha, que fuera el primer largometraje de animación europeo en color, y que dispuso para la confección de su banda sonora de la inestimable participación del maestro Jacinto Guerrero, ya para entonces (1945) considerado uno de los compositores del ámbito escénico latinoamericano y español más prestigiosos (autor destacado de zarzuelas de renombre internacional), al tiempo que, en el ámbito de la música "de consumo”, más al día de la época, como demuestra su participación en proyectos e iniciativas tan novedosos como la que representara Garbancito de la Mancha.

Palabras clave:

Garbancito de la Mancha, Arturo Moreno, Jacinto Guerrero, cine de animación, música y cine, banda sonora, dibujos animados, análisis musical, partitura, música audiovisual.

1 El presente estudio arranca de mi Trabajo de Investigación titulado Garbancito de la Mancha, análisis de la música de Jacinto Guerrero, dirigido por Héctor Julio Pérez en la Universidad Politécnica de Valencia (2007), así como con la realización, en curso, de mi tesis doctoral, en la que, entre otras cuestiones, se desarrollan los contenidos de la película, aquí sintetizados. Agradezco la colaboración y apoyo para la elaboración de este artículo de Joaquín Bisbe, Antonio Ezquerro, Rosa Galcerán, Ma Luz González, Josep Lluís i Falcó, María Manzanera, Rosa Montalt, Julio Oca, Matilde Olarte, Héctor Julio Pérez, Celestino Yáñez, la Filmoteca de Valencia (IVAC La Filmoteca) y la Fundación “Jacinto e Inocencio Guerrero". 


\begin{abstract}
:
This article is the first approach ever, from a specifically musical point of view, to the analysis and study of the film The Knight Garbancito, which was the first European full-length colour cartoon. The film had the invaluable collaboration for the making of its sound track of maestro Jacinto Guerrero, who at the time (1945) was considered one of the most prestigious composers in the Spanish and Latin American theatre circles (he was an outstanding author of world known zarzuelas). Maestro Guerrero was, at the same time, one of the most up-to-date composers of the time in popular music, as his participation in such original projects and initiatives, like The Knight Garbancito, shows.
\end{abstract}

Key words:

The Knight Garbancito, Arturo Moreno, Jacinto Guerrero, cartoons, music and cinema, sonorous band, musical analysis, score, audio-visual music.

\title{
1. INTRODUCCIÓN
}

Este trabajo tiene por objeto de estudio la música compuesta por el maestro Jacinto Guerrero Torres (*1895; †1951) para el largometraje de animación Garbancito de La Mancha (1945), del animador y realizador Arturo Moreno Salvador (*Valencia, 1909; †1994)².

Si hoy se interpelara a cualquier persona sobre cuáles cree que fueron las primeras películas de dibujos animados, seguramente respondería que las de Walt Disney, y más concretamente sus grandes clásicos, como Blancanieves y los siete enanitos (Snow White and the Seven Dwarfs, David Hand, 1937), Dumbo (Dumbo, Ben Sharpsteen, 1941) o Bambi (Bambi, David Hand, 1942) .

2 Arturo Moreno emigró con su familia a Barcelona cuando apenas contaba ocho años. Allí realizó algunos cursos de dibujo en la academia Baixas. A partir de la década de 1920 llevó a cabo diversos trabajos en publicaciones infantiles, como TBO, Pulgarcito, Pocholo, Mickey, En Patufet, etc., e hizo algunas ilustraciones para la casa de discos "Odeón". Comenzó enseguida a interesarse por los dibujos animados y, en 1930, creó un corto publicitario en blanco y negro para la casa de chocolates "Nelia" (su primera película de dibujos, de apenas un minuto de duración). En 1942 fundó la productora semi-independiente de dibujos animados "Diarmo Films", con José María Arola, y al poco tiempo también, con los dibujantes Armando Tosquellas y Rosa Galcerán Vilanova [*Barcelona, 1917]. Desde esta productora realizó "spots" publicitarios para Bayer y un cortometraje (con el que se estrenó "Diarmo Films" — nombre extraído de "Dibujos Animados Arola y Moreno"), El capitán Tormentoso (1942), que le sirvió de tarjeta de presentación. Con ella, Arturo Moreno se dispuso a buscar una distribuidora, hasta que encontró la llamada "Balet y Blay” (encabezada por Ramón Balet Raurich y José M $M^{\mathrm{a}}$ Blay Castillo). Así, José $\mathrm{M}^{\mathrm{a}}$ Blay propuso a Arturo Moreno la realización de un largometraje de dibujos animados en color: Garbancito de la Mancha. Después del gran éxito, se llevó a cabo una segunda parte, Alegres vacaciones (1948). Más tarde, Arturo Moreno se marchó a Venezuela, donde dirigió una revista pedagógica infantil, Tricolor, contratado por el Ministerio de Educación de dicho país y realizó diversos "spots" publicitarios. En 1956 regresó a España, donde hizo colaboraciones como dibujante en publicaciones infantiles, y fallecería 38 años más tarde. MANZANERA, 1992: 23. CANDEL CRESPO, 1993: 46.

3 Intentando hacer memoria, pronto se recordarían otras producciones más recientes como La sirenita (The Little Mermaid, John Musker y Ron Clements, 1989), Aladdin (John Musker y Ron Clements, 1992) o El rey León (The Lion King, Rob Minkoff y Roger Allers, 1994). Incluso, en el caso de tener hijos, hecho que hoy en día convierte a cualquiera en espectador "obligado" de este tipo de productos, sin duda alguna, saldrían a relucir otros nombres de filmes todavía más actuales, como Monstruos S. A. (Monsters, Inc., Pete Docter, Lee Unkrich y David Silverman, 2001), Los increíbles (The Incredibles, Brad Bird, 2004), Cars (John Lasseter, 2006) o Enredados (Tangled: Rapunzel, Nathan Greno y Byron Howard, 2010). De hecho, normalmente el género se asocia con el público infantil, aunque cada vez más encontramos un mayor número de espectadores adultos interesados en él. Por su parte, directores y guionistas también optan por hacer películas que, aunque siguen estando pensadas para los niños, los padres puedan verlas y disfrutarlas de forma compartida, tales como Shrek (Andrew Adamson y Vicky Jenson, 2001), Ice Age: La edad de hielo (Ice Age, Chris Wedge y Carlos Saldanha, 2002) o Madagascar (Eric Darnell y Tom McGrath, 2005). También existen producciones en las que la animación se convierte en una opción diferente de plasmar el discurso fílmico, como Final Fantasy: La 
Si preguntamos, en cambio, por el cine de animación español, las referencias son mucho más escasas ${ }^{4}$. Pero difícilmente se imaginará que el primer largometraje de animación en color, "europeo", fuera la producción española titulada Garbancito de la Mancha $a^{5}$ estrenada nada menos que en 1945 (!).

Pero las sorpresas no terminan aquí: al consultar la ficha técnica del film disponible en la base de datos de películas calificadas del Ministerio de Educación, Cultura y Deporte, se descubre que su banda sonora fue realizada nada menos que por el maestro Guerrero, un autor especialmente conocido en ámbito hispánico, por su faceta como compositor de zarzuelas.

Con tales datos (considerando que se trata de una producción española realizada en plena posguerra), podría pensarse que el resultado audiovisual conseguido no alcanzara el grado de calidad de otras creaciones cinematográficas coetáneas llevadas a cabo por la industria estadounidense. Pero nada más lejos de la realidad. Y lo mismo sucede con la música de la película, la cual puede considerarse uno de los mejores valores de la producción ${ }^{6}$.

fuerza interior (Final Fantasy: The Spirits Within, Hironobu Sakaguchi y Motonori Sakakibara, 2001), e incluso algunas de ellas se destinan a un público adulto, como El gato caliente (Fritz the Cat, Ralph Bakshi, 1972), Historias de amor y de masacre (Jorge Amorós, 1979) o South Park: Imaginationland (South Park: Imaginationland: The movie, Trey Parker, 2008).

4 Como éxitos más recientes contamos con los largometrajes de animación Planet 51 (Jorge Blanco, Javier Abad y Marcos Martínez, 2009) —al estilo de las grandes producciones de Hollywood-y Chico \& Rita (Fernando Trueba, Javier Mariscal y Tono Errando, 2010) — primera película de animación de Fernando Trueba con dibujos originales de Javier Mariscal-.

5 En los últimos años se han llevado a cabo diversos estudios sobre el cine español, que han desembocado en hallazgos sorprendentes: recientemente, se ha conocido que Concha Piquer protagonizó la primera película sonora en castellano en 1923, por delante de El misterio de la puerta del sol [Francisco Elías, 1929], film que hasta el momento ostentaba ese lugar en la historia; y que incluso se adelanta a los dos films dirigidos por Alan Crosland, Don Juan [Don Juan, 1926], que ofrecía los primeros sonidos de la historia del cine e incorporaba música de Mozart y efectos de sonido, y El cantor de jazz. [The jazz singer, 1927], la cual se considera la primera película hablada de la historia del cine. Es una producción norteamericana de 11 minutos, que fuera rodada por Lee DeForest, en la que la conocida actriz y cantaora — folclórica — valenciana, baila y canta una jota aragonesa, un cuplé andaluz e incluso un fado portugués. Fue descubierta en la Biblioteca del Congreso de Washington por Agustín Tena, mientras preparaba el guión de un documental sobre Conchita Piquer para TVE. Algo semejante está sucediendo también con el cine de animación español, y con la película que nos ocupa, aunque en este caso, los resultados de las investigaciones muy de vez en cuando dan lugar a cierta labor de divulgación. Un buen ejemplo de ello es el artículo periodístico de J. M. Prada que intenta dar a conocer Garbancito de la Mancha, poner en valor la calidad de nuestro cine histórico y conseguir que deje de ser un gran desconocido. [Véase: PRADA, 973 (21.11.2010)].

6 En este sentido, he optado por focalizar el análisis más detenido en torno a la música de Jacinto Guerrero, sin dejar por ello necesariamente de lado el resto de elementos constitutivos del film y el contexto en el que se creó. Se trataría de aproximarse a la época dorada del cine de animación español y de reconocer y valorar las aportaciones llevadas a cabo por el compositor en la música de esta película: instrumentación, estilo, lenguaje compositivo, etc. 


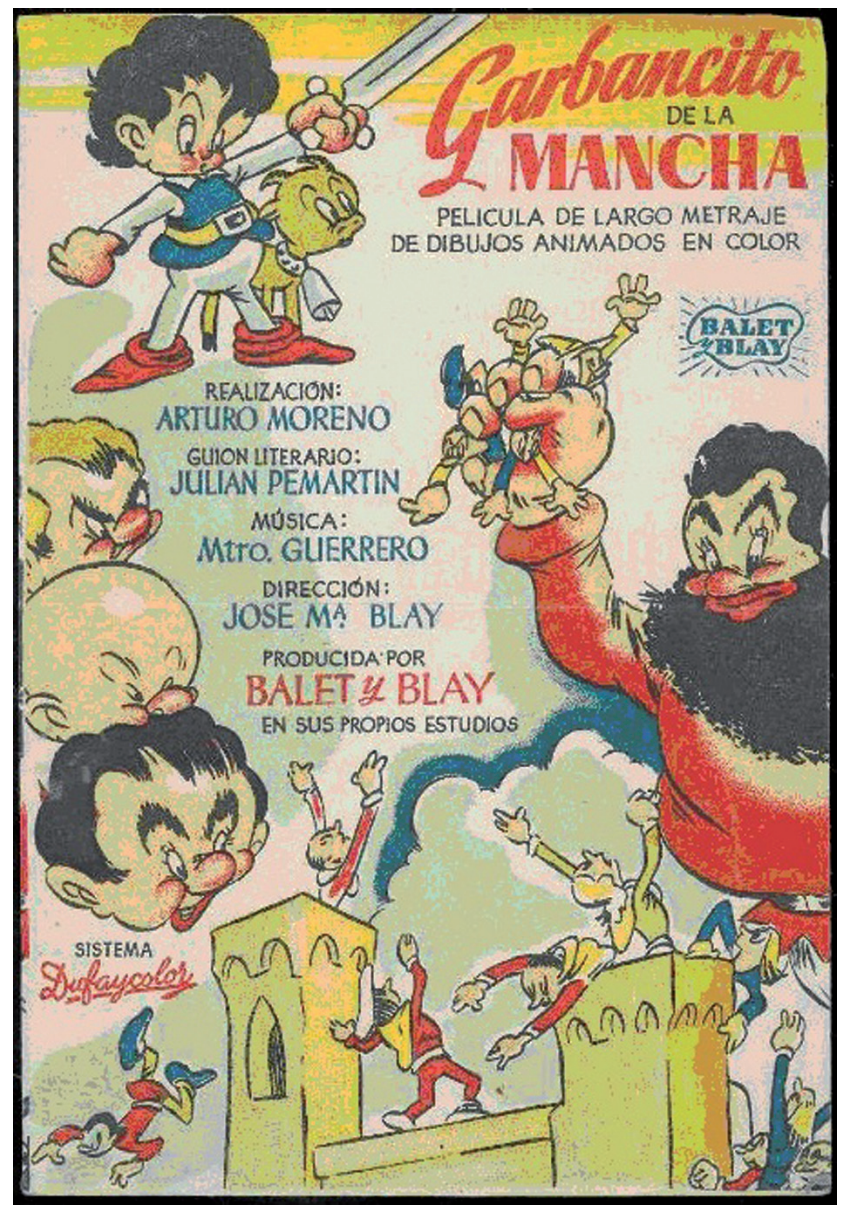

Figura 1. Cartel anunciador de Garbancito de la Mancha (1945)

Sin duda, el cine ha propiciado numerosos estudios y puede decirse que, de la totalidad de sus elementos constitutivos, en términos generales, la música — junto con el sonido — se presenta como la "eterna olvidada" . A pesar de ello, desde la década de 1930 hasta la actualidad, encontramos numerosos trabajos que han tratado el papel que desempeña la música en la construcción del texto fílmico, teniendo una especial incidencia a partir de la década de 1980. Así, conviene destacar al menos las aportaciones de

7 Según declara M. Chion, "hasta hoy, las teorías sobre el cine, en conjunto, han eludido prácticamente la cuestión del sonido: unas veces dejándola de lado y otras tratándola como un terreno exclusivo y menor. Aunque algunos investigadores hayan propuesto aquí y allá enfoques muy valiosos sobre la cuestión, sus aportaciones [...] no han ejercido aún suficiente influencia como para imponer una reconsideración del conjunto del cine, en función del lugar que en él ocupa el sonido desde hace sesenta años". CHION, 1993: 11. 
H. Eisler y Th. Adorno, C. Gorbman o R. Altman, entre otros ${ }^{8}$. Pero una de las aportaciones más significativa en el ámbito internacional es, sin duda alguna, la de M. Chion. Así como, para el caso concreto de España, las aportaciones de J. Padrol y M. Valls Gorina, M. Gertrudix Barrio o J. L. Falcó, sin olvidar a J. Nieto ${ }^{10}$.

Pero si las referencias bibliográficas sobre la música de cine, desde una perspectiva general, no son muy abundantes en el ámbito hispánico, menos lo son aquellas que se ocupan de un género tan particular como es el cine de animación. Aunque existen escasos estudios que aborden específicamente el estudio de la música en este género cinematográfico en el ámbito hispánico ${ }^{11}$, sí se puede afirmar que, en todos los trabajos sobre animación -y una parte importante de los que versan sobre cine en general- se recoge alguna referencia, siquiera sea breve, al papel que desempeña la música.

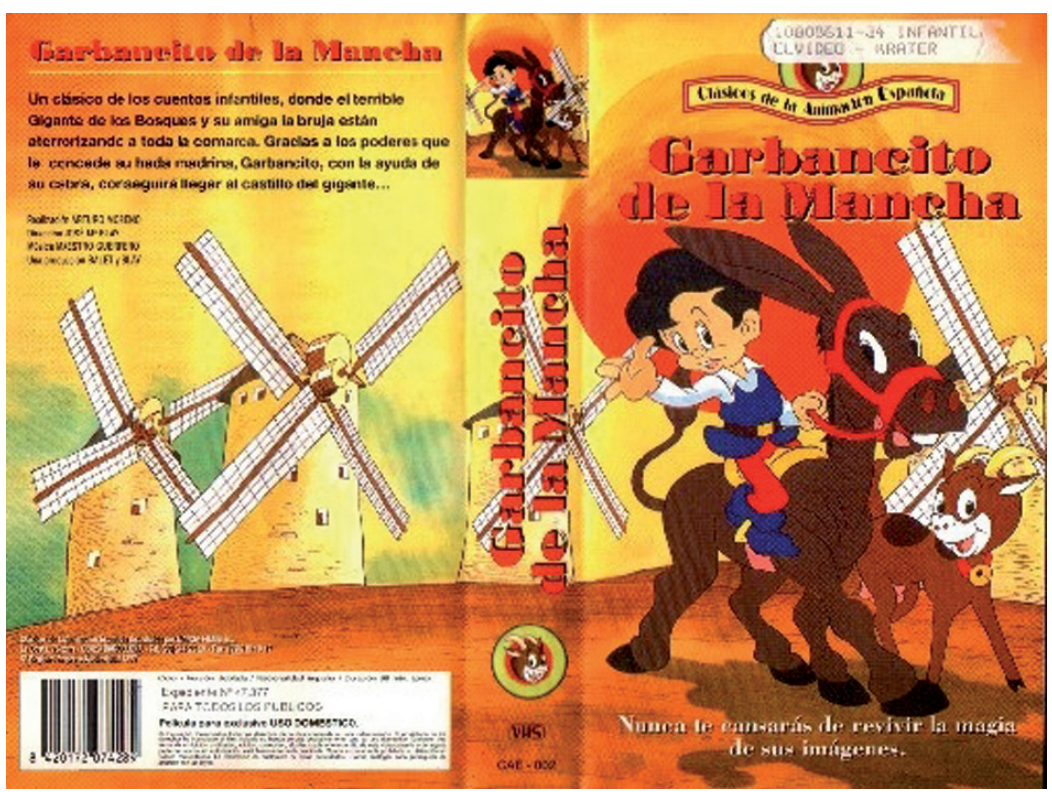

Figura 2. Carátula de Garbancito de la Mancha en formato VHS

8 ADORNO y EISLER, 1976. GORBMAN, 1987. ALTMAN, 1992. Obviamente esta lista podría ser muy extensa, de modo que me limito aquí a ofrecer algunos de los nombres más destacados a lo largo del tiempo.

9 CHION, 1993; 1997; 1999.

10 PADROL y VALLS GORINA, 1990; NIETO, 1996. GERTRUDIX BARRIO, 2003. LLUÍS I FALCÓ, 1995, nº. 21: 169-186.

11 ARÓSTEGUI PLAZA, 2009: 553-563. MALETÁ COCIÑA, 2009: 553-563. RADIGALES, 2001: 107-122. Como referencias bibliográficas en otros idiomas, conviene mencionar: GOLDMARK, y TAYLOR, 2002. GOLDMARK, 2005. 


\section{FICHA TÉCNICA Y ARTÍSTICA ${ }^{12}$}

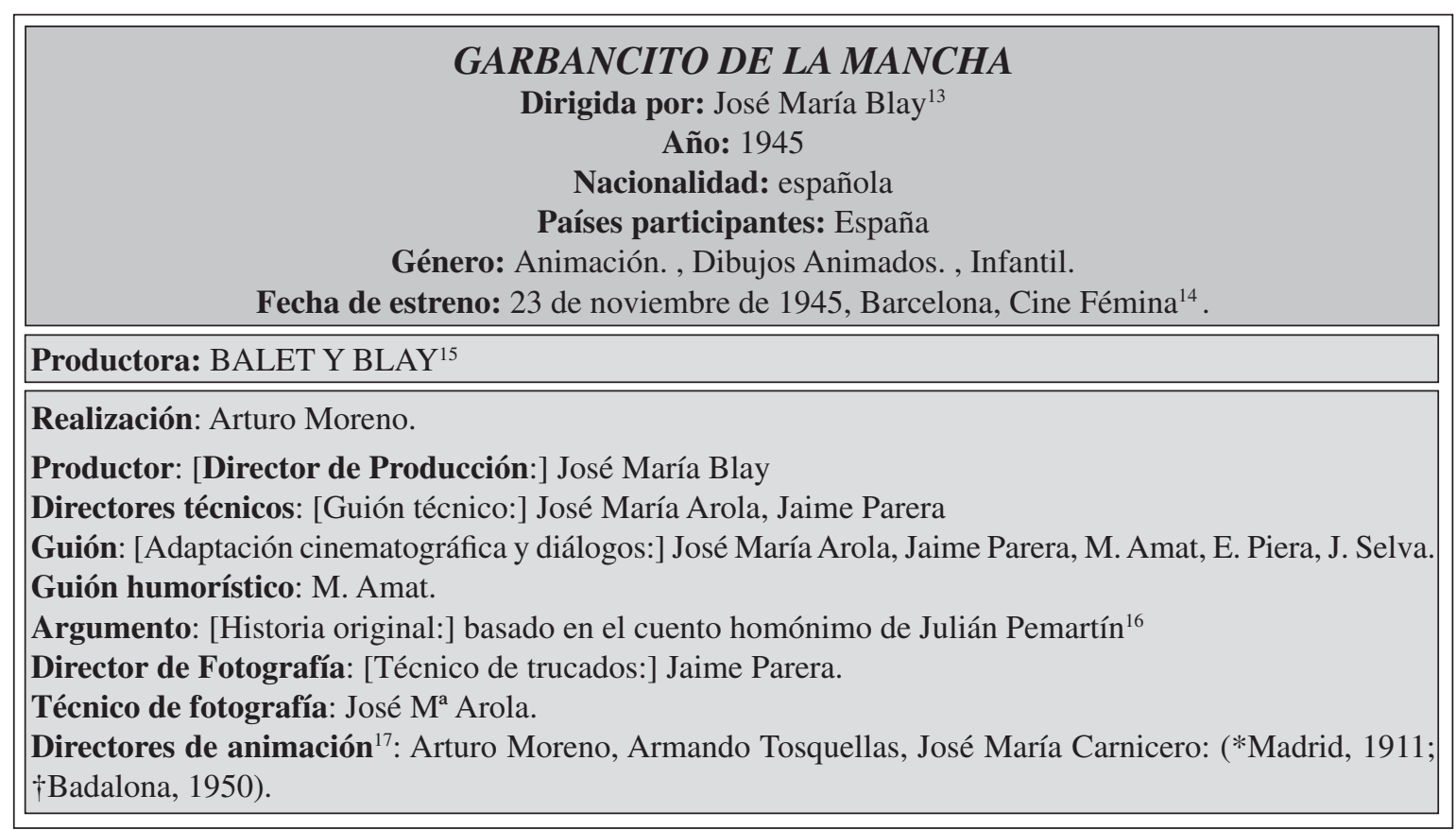

12 Extraída de la base de datos de películas calificadas del Ministerio de Educación, Cultura y Deporte: "http://www.mcu. es/bbddpeliculas/buscarDetallePeliculas.do?brscgi_DOCN=000002666\&brscgi_BCSID=1de603a8\&language=es\&prev_layout= bbddpeliculasResultado\&layout=bbddpeliculasDetalle [Acceso: 17.06.2005]”.

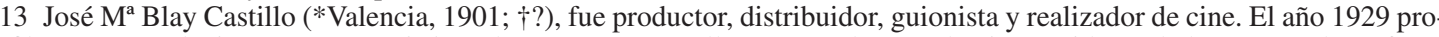
dujo el film propagandístico La España de hoy, de Francesc Gargallo. Ocupó el cargo de vicepresidente de la Cámara de Defensa Cinematográfica Española desde 1934 (y en la década de 1940). Durante la década de 1930 fue director-gerente, sucesivamente, de la productora Febrer y Blay (que hizo uno de los musicales más populares del cine español: ;Abajo los hombres!), de la productora y distribuidora "Balet y Blay" (que fundó en 1938 junto con Ramón Balet Raurich), y de la empresa distribuidora Cinedía S.A. (con la que se asoció posteriormente). Fue supervisor (una suerte de co-director), junto a Arturo Moreno, de Garbancito de la Mancha (1945) y de Alegres vacaciones (1947), aunque en los títulos de crédito aparece como director, así como de los Sueños de Tay-Pi (junto a Franz Winterstein, 1951). CRUSELLS, 2008: 56. CANDEL CRESPO, 1993: 46.

14 El cine Fémina (Paseo de Gracia, 23, Barcelona) fue inaugurado el 16 marzo 1929. El 7 de abril de 1991 sufrió un grave incendió que lo dejó en situación de "siniestro total" por lo que fue derribado y desapareció definitivamente. La Vanguardia (16.03.1929):19; (08.04.1991): 19. CASTILLO y AZORÍN 61/515, (julio-septiembre 2009); 35-48. El film se exhibió allí durante dos semanas, tras lo cual pasó al barcelonés Cine Publi, donde prosiguió en cartel durante otras ocho semanas. También se estrenó con gran éxito en Madrid, el 13.05.1946, en el Palacio de la Música. CORTIZO, 2000, vol. 6: 44-52.

15 "Balet y Blay" fue una productora y distribuidora española creada por José María Blay Castillo y Ramón Balet Raurich en 1938 (con oficinas en el Paseo de Gracia, 83, Barcelona). [La Vanguardia, 5.09.1938:12]. Produjo tres de los cuatro largometrajes de animación que se realizaron durante la década de 1940 en nuestro país, década de oro del cine de animación español: Garbancito de la Mancha (1945), —debido al gran éxito obtenido, se produjo una segunda parte—, Alegres Vacaciones (1948) —que no obtendría los mismos resultados—; y Los sueños de Tay-Pi (1952) — fue la última producción de Balet y Blay, que, ante un estrepitoso fracaso, cerró sus puertas definitivamente-.

16 Julián Pemartín Sanjuán $(* 1901 ; \nmid 1966)$ licenciado en Derecho, fue escritor, poeta y militante falangista. Antes de la guerra civil, colaboró en la revista Acción Española (ideológicamente cercana a Falange Española). Finalizada ésta, fue nombrado Director del Instituto Nacional del Libro Español (cargo que ocupó hasta su muerte en 1966). Fue responsable de la política del libro (edición, impresión, difusión, comercialización...) y "artífice” de la Ley de Protección al Libro Español de 12.12.1946.

17 Para formar el equipo de dibujantes, ya que sólo se contaba con Armando Tosquellas y Rosa Galcerán, aparte de Arturo Moreno, "[...] se mandaron circulares a todas las academias de dibujo de Barcelona, que enviaron unos 150 dibujantes, los cuales eran sometidos a una prueba consistente en hacer un dibujo sobre plancha de celofán y los que salían airosos eran admitidos". MANZANERA, 1992: 24 
Animación: Francisco Jordá, José $\mathrm{M}^{\mathrm{a}}$ Vendrell, Rosa Galcerán (*Barcelona, 24.11.1917), Edith Frank, P. García, José María Carnicero, Manuel Roncero, Jaime Parera, P. García.

Diseño (de Pajarón, Pelanas y Manazas): Eusebio Pantaleón Oca Pérez (*Alicante, 27.07.1916; †Barcelona, 19.04.1985).

Iluminadora: Isabel Masanet Robles (*Alicante, 24.02.1915; †Navata, Gerona, 01.08.2009).

Filmación: José Ma Arola, Jaime Parera, Enrique Vilarrasa.

Fotografía de animación: [Operadores:] José María Maristany, Enrique Vilarrasa.

Fotografía: Jaime Parera, José María Maristany.

Fondos [Dibujantes de fondos:]: Francisco Tulla, Valentín Castanys.

Colorido: Ana $\mathrm{M}^{\mathrm{a}}$ Melero.

Música: Jacinto Guerrero.

Canciones y bailables: Joaquín Bisbe ${ }^{18}$.

Canciones interpretadas por: Cuarteto Vocal "Orpheus" ${ }^{19}$, Pepita Russell ${ }^{20}$ y Cayetano Renom ${ }^{21}$.

Sistema de Sonido: Parlo Films ${ }^{22}$

Sonido: Mono.

Formato [de producción]: $35 \mathrm{~mm}$. Dufaycolor ${ }^{23}$. Normal.

Formato [de proyección]: 1.37:1.

Duración original: 98 minutos

Rodaje y Montaje

Metraje: 2700 metros [finalmente, 2220]

18 Toda la música de Garbancito de la Mancha fue compuesta por el maestro Guerrero a excepción del "Número [musical] de los gusanos" (del que se hablará posteriormente) que estuvo a cargo de Joaquín Bisbe Piqué (*Barcelona, 01.04.1924). Joaquín Bisbe inicia su formación musical con su padre, violonchelista y contrabajista aficionado. Con 10 años ingresa en el Conservatorio de Municipal de Barcelona donde cursa estudios de solfeo y algunos años de piano. Debido a su interés por el jazz, realiza los estudios de trompeta, y también recibe clases de armonía y composición del afamado pedagogo y compositor catalán Cristòfol Taltabull. Desde joven forma parte de orquestas de bailes con las que realiza giras por toda Europa. Durante toda su vida ha compaginado esta labor con la composición y la realización de arreglos. Por lo que se refiere a Garbancito de la Mancha, participó en una doble faceta: como animador y como músico. Dibujante aficionado, intervino en el proceso de animación como intercalador; y en su faceta de músico, la más relevante, fue el pianista repetidor de la partitura de J. Guerrero y realizó la composición del maravilloso "Número [musical] de los gusanos". Este último constituyó sin duda una de las partes imprescindibles de la película.

19 Su componente más relevante fue el tenor Gaietà Renom (*Barcelona, 1913; †1997). Este Cuarteto Vocal participó en diversas películas de la época, como El difunto es un vivo (1941), Un enredo de familia (1942) o Un marido a precio fijo (1942), interpretando canciones de corte jazzístico. Cabe pensar que debido a su experiencia en este tipo de canciones, fueron elegidos para cantar en el "Número [musical] de los gusanos" y la "Canción de los «chopos»". ROMAGUERA I RAMIÓ, $2002: 79$.

20 Pepita Russell formaba parte del Trío Vocal "Hermanas Russell" que, junto a Albalat, cantaban en títulos tan famosos en la década de 1940 como "Hoy es tu cumpleaños" o "Para bailar el bugui".

21 Formó parte de la escolanía de San Felipe Neri del barrio de Gracia, del "Orfeó Català" y del Cuarteto Vocal "Orpheus" (con los que cantó en Garbancito de la Mancha). Destacan sus interpretaciones, dirigido por Lluís Maria Millet (*1906; †1990), de buena parte de los grandes oratorios, misas y conciertos de los compositores clásicos europeos, traducidos al catalán. Grabó canciones, sardanas y tres EP $(1964,1966)$. ROMAGUERA I RAMIÓ, 2002: 70.

22 Empresa barcelonesa dedicada al doblaje y sonorización (sincronización, montaje, etc.) de películas que fue comprada por el afamado director Ignacio Ferrés Iquino $(* 1910 ; \dagger 1994)$ en 1953.

23 Así se conoce el proceso fotográfico aditivo que desarrolló Louis Dufay (1908) y su proceso cinematográfico derivado. Este último, consistía en hacer pasar la luz a través de un filtro tricolor constituido por una pantalla de micropuntos de colores rojo, verde y azul, distribuidos en mosaico (geométricamente), para impresionar una emulsión de Dufaycolor (halogenuro argénteo fotosensible). 
Laboratorios: DUFAY CHROMEZ (Londres) ${ }^{24}$, CINEFOTO (Barcelona) ${ }^{25}$. Lugares de rodaje: Estudios "Balet y Blay" S.L. (Barcelona). DATOS DE DISTRIBUCIÓN ${ }^{26}$ (totales; por distribuidora —empresa distribuidora: CINEDIA S. A.— ${ }^{27}$ ): Espectadores: 130.523; Recaudación: 33.628,33€

\section{LA PELÍ́CULA ${ }^{28}$}

Existen varios ejemplares de la película. Así se han localizado copias en $35 \mathrm{~mm}$ en celuloide original en tres de las filmotecas más relevantes de nuestro país: Filmoteca Española, Filmoteca de Andalucía (Córdoba) y Filmoteca de Catalunya. También existen numerosas ediciones en formato doméstico, Beta o VHS (Vértice Producciones, Thor Films Vídeo Producciones, Manga Films y Huracán Films) y las copias en VHS no editadas de las distintas filmotecas ${ }^{29}$.

Tras una preparación de seis meses (en los que se acondicionó un edificio en lo que entonces eran las afueras del casco urbano, en la calle de Nuestra Señora del Coll, en el entorno de Vallcarca, cercano al Tibidabo $^{30}$ ), el trabajo comenzó a finales de 1943 y concluyó a principios de 1945. Garbancito de la Mancha se estrenó el 23 de noviembre de 1945 en Barcelona y el 13 de mayo de 1946, en Madrid, con un éxito rotundo.

$24 \mathrm{Al}$ elegir el sistema Dufaycolor para revelar las fotos de la película, los rollos se tuvieron que enviar a los laboratorios "Dufay Chromez" de Londres (y en este sentido, aunque mínimamente, la película todavía fue en cierto modo dependiente del más avanzado sistema técnico británico), ya que en España todavía no existía ningún laboratorio que aplicase dicho sistema. CANDEL CRESPO, 1993: 46.

25 Los laboratorios "Cinefoto" se encargaron de los aspectos técnicos de la película. Estos laboratorios fueron creados por Daniel Aragonés (La Vanguardia, 22.07.1933:14) y estaban situados en la calle Lauria, 85, de Barcelona (El Mundo deportivo, 27.09.1934: 4). Más tarde se unirá al proyecto un tal Pujol (La Vanguardia 13.05.1936:13), al que se hace referencia como copropietario del laboratorio. Este artículo se hace eco de la constitución de una nueva sociedad formada por los laboratorios "Cinefoto" y los estudios de "Orphea Film", después de un incendio que había destruido estos estudios: "dentro de poco constituirá el mejor estudio de producción de España y uno de los primeros de Europa". Los laboratorios "Cinefoto" continuaron su labor en años posteriores, llegando a tener gran relevancia ya que Daniel Aragonés (hijo) desarrolló, a partir de 1947, el sistema Cinefotocolor el sistema Cinefotocolor en sus laboratorios Cinefoto de Barcelona (véase el documento de la Filmoteca Española titulado "Identificación técnica del material":

"http://www.mcu.es/cine/MC/FE/Documentacion/InspeccionTecnicaHTM/07-InspeccionTecnica-3Parte3.htm" [Acceso: 22.11.10].

26 Si la información sobre los datos de distribución que aparece en la base de datos de películas calificadas del Ministerio de Educación, Cultura y Deporte es correcta, Garbancito de la Mancha tuvo un número de espectadores y una recaudación que no encuentran parangón en las películas de la época. Así, grandes títulos como Los últimos de Filipinas (1945) —declarada de interés nacional, con datos totales de distribución: 29.966 espectadores y $2.720,25 €$ de recaudación-, El destino se disculpa (1945) —declarada de interés nacional, con datos totales de distribución: 2.231 espectadores y 120,74 € de recaudación- o Locura de Amor (1948) — declarada de interés nacional, con datos totales de distribución: 24.177 espectadores y 1.937,04 € de recaudación — se quedan muy por detrás. Encontramos unos resultados más elevados en la película Currito de la cruz (1948) —con datos totales de distribución: 182.000 espectadores y $15.983,12 €$ de recaudación— aunque sigue obteniendo unas cifras muy inferiores a las que consiguió Garbancito de la Mancha: 130.523 espectadores y 33.628,33 € de recaudación (!!!).

27 Empresa distribuidora creada en 1940, que se asoció más tarde con "Balet y Blay" para producir films publicitarios y distribuir largometrajes comerciales.

28 Para conocer los antecedentes de la película, desde los orígenes del cine de animación en España hasta la producción de la década de 1940 (considerada la Edad de Oro de la animación española), véase CANDEL CRESPO, 1993: 15-76. DE LA ROSA, 2003: 469-508. MARTÍNEZ BARBUENO, 2003: 17-38.

29 La copia que posee la Filmoteca de Valencia (IVAC La Filmoteca) ha sido la fuente principal que se ha utilizado para realizar el análisis fílmico. Además, se han consultado las otras fuentes para completar la información.

30 TORRELLA PINEDA, 1991, 2: 79-85. 


\section{. El Director \\ de \\ Balet y Blay, S. L. \\ y ja \\ Empresa "Cine Fémina" \\ Saludan}

al público de Barcelona

Y le agradecen el magnifico acogimiento dispensado, el viernes por la noche,

a la película "GARBANCITO DE LA. MANCHA».

Igualmente se creen en el deber de manifestar su reconocimiento a las Dignísimas Autoridades de la ciudad que con su asistencia honraron este solemne acto. A las Radios locales y de Badalona les damos las gracias por su cordial colaboración, al Noticiario Español NO-DO le guardamos nuestro reconocimiento por su excepcional labor así como a la Prensa que, cariñosamente, nos ha alentado $\mathrm{y}$ se ha hecho pleno eco de nuestro esfuerzo $\mathrm{y}$ finalmente damos las gracias a todos les colaboradores que han contribuído con su tarea a que el exito de "GARBANCITO DE LA MANCHA» haya constituido un legítimo triunfo del cine español.

Figura 3. Recorte de prensa, La Vanguardia española, 25.11.1945, p.14.

\begin{tabular}{|c|c|c|}
\hline & & \\
\hline 0. & "Los crimenes dol Fantasma» & \\
\hline & (2n jornada), «El sospechosos & \\
\hline A11 & PUBII. - Continua desde las & 3 \\
\hline in & 5 tarde: No-Do, El & \\
\hline & tórico proceso de Nuremberg; & \\
\hline a- & Imágenes núm. 52, Escuelas & \\
\hline 012 & neoyorquinas: 6.2 semana de & \\
\hline e. & clamoroso éxito & \\
\hline मे, & "Garbancito de la Mancha" & \\
\hline 0. & HaMULAS. - "LOS crimenes & \\
\hline as & del fantasma) (2.a jornada), & \\
\hline án & «Héroes del mar" y No-Do. & \\
\hline & $\begin{array}{l}\text { "El sospe. } \\
\text { invisibler }\end{array}$ & \\
\hline & (2.a jornada) y Not. No-Do. & 5 \\
\hline
\end{tabular}

Figura 4. Cartelera. La Vanguardia española, 03.01.1946, p.14. 
Fue el primer largometraje de animación en color europeo. Entretanto, la industria americana de este género se encontraba en pleno desarrollo; por ello, únicamente es coherente comparar este film con las producciones estadounidenses de aquella época ${ }^{31}$ — que tendrán una influencia decisiva en la creación española - desde el punto de vista creativo y artístico, pero no así desde el técnico. El gigante Walt Dis$n^{32}$ ya había producido numerosos y exitosos largometrajes de animación en color: Blancanieves y los siete enanitos [Snow White and the Seven Dwarfs, David Hand, 1937], Pinocho [Disney's Pinocchio, Ben Sharpsteen y Hamilton Luske, 1940], Fantasía [Fantasia, Ben Sharpsteen, 1940], Dumbo [Dumbo, Ben Sharpsteen, 1941], Bambi [Bambi, David Hand, 1942] y Los tres caballeros [The Three Caballeros, Norman Ferguson, 1945]. También los hermanos Fleischer habían estrenado Los viajes de Guilliver [Gulliver's Travels, Dave Fleischer, 1939] y Hoppity va a la ciudad [Hoppity Goes to Town, Dave Fleischer, 1941] ${ }^{33}$.

En cuanto a Garbancito, puede parecer sorprendente que, pese al cúmulo de factores negativos que concurrían en el momento -posguerra española, Segunda Guerra Mundial, etapa de autarquía y absoluta escasez de recursos técnicos, económicos y humanos, etc. ${ }^{34}-$, este largometraje de dibujos animados en color se llevara a cabo con unos resultados excelentes, tanto en el ámbito nacional como europeco ${ }^{35}$.

31 "Esta circunstancia es explicable porque tanto Disney como los Fleischer [hermanos competidores...] habían llegado a estos resultados después de un largo proceso que había durado algo más de una década, mientras que en nuestro país no existían prácticamente ni una tradición ni una industria sólida" CANDEL CRESPO, 1993: 50.

32 Walter Elias Disney Jr. (*1901; †1966) creó en Hollywood (1923), con la colaboración de su hermano, la Disney Production que en la actualidad es un auténtico imperio industrial (canales de televisión, parques temáticos, editoriales, etc.) y sin duda alguna es la factoría de animación más importante de todos los tiempos. La lista de producciones es interminable a los ya citados podemos añadir Cenicienta [Cinderella, Clyde Geronimi, Hamilton Luske, Wilfred Jackson, 1950], La Dama y el Vagabundo [Lady and the Tramp, Clyde Geronimi, Hamilton Luske y Wilfred Jackson, 1955], La bella durmiente [Disney's Sleeping Beauty, Clyde Geronimi, 1959], 101 Dálmatas [101 Dalmatians, Wolfgang Reitherman, Clyde Geronimi y Hamilton Luske, 1961], Merlín el encantador [Sword in the Stone, Wolfgang Reitherman, 1963], El libro de la selva [The Jungle Book, Wolfgang Reitherman, 1967], Los Aristogatos [The Aristocats, Wolfgang Reitherman, 1970], La bella y la bestia [Beauty and the Beast, Gary Trousdale y Kirk Wise, 1991], Buscando a Nemo [Finding Nemo, Andrew Stanton y Lee Unkrich, 2003], Wall-E [Wall-E, Andrew Stanton, 2008], etc.; y sus personajes han alcanzado una gran fama, comparable a cualquier superestrella de Hollywood (Mickey, el pato Donald, Peter Pan, Ariel, Pocahontas, etc.)

33 Max Fleischer $(* 1889 ; \nmid 1972)$ y Dave Fleischer $(* 1894 ; \dagger 1979)$ se establecieron de manera independiente en 1912, creando la "Out of The Inkwell Film Inc.", considerado el estudio de animación norteamericano más significativo, únicamente por detrás de la casa Disney. Alcanzaron el éxito con Betty Boop [Betty Boop, 1931] y Popeye el marino [Popeye the Sailor, Dave Fleischer y Seymour Kneitel, 1933]. Más tarde, tendrían que conformarse con la producción de dos largometrajes, Los viajes de Gulliver [Gulliver's Travels, Dave Fleischer, 1939] y Hoppity va a la ciudad [Hoppity Goes to Town, Dave Fleischer, 1941], que resultarían muy costosos y que conseguirían escaso éxito, lo que les obligó a cerrar el estudio.

34 "No se contaba con estudios para realizar la película ni con dibujantes profesionales, a excepción de Arturo Moreno. Tampoco había maquinaria ni planchas de celuloide [...]”. El propio “Arturo Moreno se encargó de diseñar la «truca» y unos tableros giratorios para los animadores, todo según fotografías y según le dictaba la experiencia de largos años de dibujante, ya que nunca había visto unos estudios de animación [...]" MANZANERA, 1992: 24. Por lo que respecta a la materia prima, "como en España en esta época no se fabricaban celuloides se hizo preciso comprar en Suiza tres toneladas de dicho material (unas cuatrocientas mil planchas), pero cuando el tren que las transportaba atravesaba Francia fue bombardeada una estación del trayecto y el preciado material quedó abandonado en una vía muerta. Durante más de un mes, Moreno y sus colaboradores estuvieron sin saber dónde había ido a parar el celuloide, que resultaba imprescindible para la realización de la película. Y es que el desarrollo de la Guerra Mundial fue salpicando toda la realización de «Garbancito de la Mancha»". "[...]El sistema elegido fue el Dufay Chrome, [como ya se ha explicado anteriormente], y cada vez que se fotografía un rollo de película era preciso enviarlo a Londres para su revelado. Estos envíos coincidieron con la época del 'blitz' alemán sobre Inglaterra, cuando la capital británica estaba sometida a los terribles bombardeos de la Luftwaffe.”. CANDEL CRESPO, 1993: 46.

35 "La película, no obstante, estaba repleta de detalles ingeniosos y fue acogida con cariño por el público, y no sólo en España sino también en el extranjero, donde los críticos y técnicos le prodigaron grandes elogios". [Ibíd.: 50]. Garbancito de la Mancha logró una amplia difusión, siendo aclamada en Inglaterra (donde se tituló "The Knight Garbancito"), aunque también se comercializó en otros países del este, como la República Checa (bajo el título de "The Enchanted Sword") y obtuvo cierta popularidad en Francia (con el nombre de "Le Chevalier Garbancito"). 


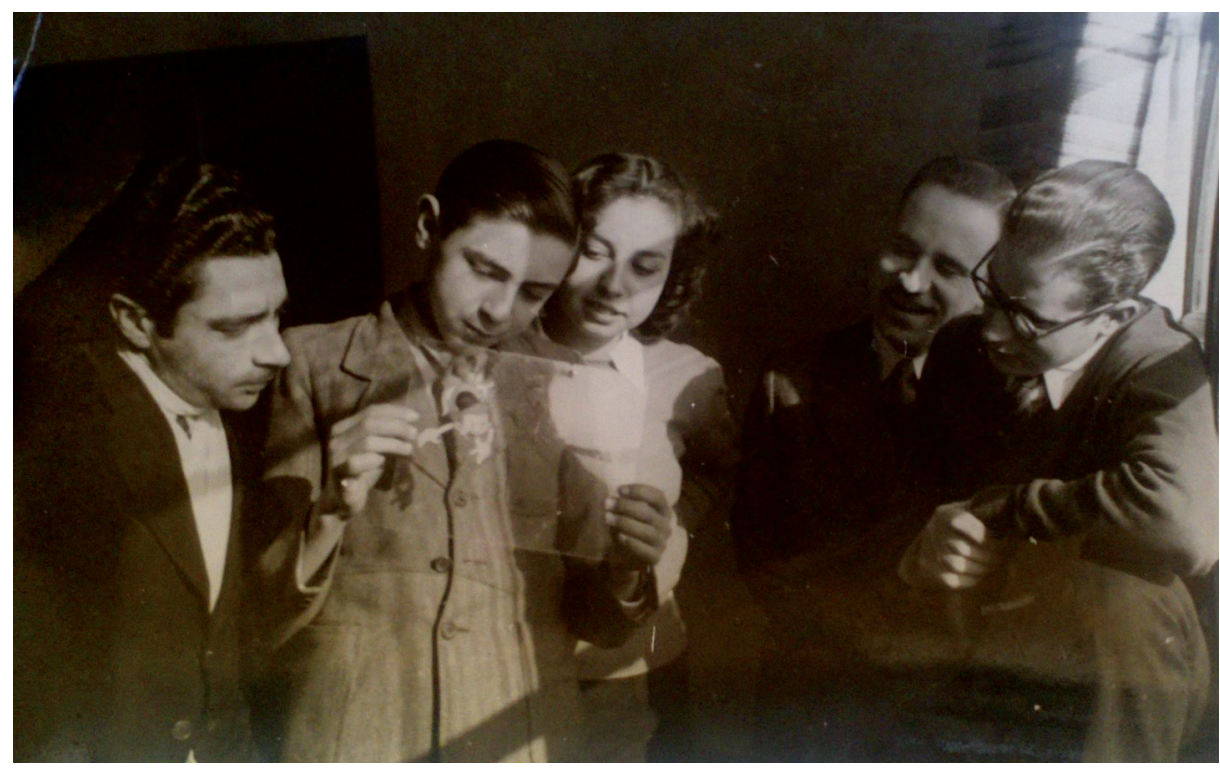

Figura. 5. Grupo de animadores observando el acetato (1944). En el reverso de la foto se lee: "Cortando un traje a Moreno 8-I-44". De izda. a dcha., Eusebio Oca, Hidalgo, Monserrate, Heiman y Joaquín

Bisbe, examinando un acetato

Para poder entender cómo se gestó la producción de Garbancito de la Mancha, es necesario remontarnos al inicio de la década:

"Si bien la industria [española] había salido maltrecha por el conflicto armado, la recuperación de la misma durante la primera mitad de la década hizo posible la aparición de este tipo de películas en nuestro país.

En 1943, coincidiendo con el apogeo generalizado de la producción [cinematográfica] en nuestro país, se consigue una cota nada desdeñable de 32 producciones, casi el doble que el año anterior, produciéndose una ligera bajada en 1944, coincidente también con la bajada de la producción general. A pesar de todo, se realizaron en cinco años la friolera de 105 cortometrajes de animación, una cantidad realmente llamativa, y que pone de manifiesto el asentamiento, de una parte del engranaje industrial cinematográfico dentro de este sector" ${ }^{\prime 6}$.

De esta manera, con una realización artesanal (prácticamente hecha a mano), se hizo posible llevar a cabo un proyecto tan ambicioso.

"Esta singular producción pronto acaparó la atención de los medios de comunicación y sirvió como ejemplo de ensalzamiento de la industria nacional ya que comenzó su realización en 1944, año en el que se detecta un decrecimiento de la producción cinematográfica [...]"37.

36 ROLDÁN GARROTE, 2003: 114-115.

37 Ibíd.: 115. 
En contraste con aquel proyecto y para evitar dicha tendencia negativa y fomentar el crecimiento de la producción, el gobierno franquista llevó a cabo una serie de medidas legislativas novedosas, que constituyen un hito en la historia del cine español ${ }^{38}$. De esta manera, la creación cinematográfica se someterá principalmente a dos formas de control: la represión y la protección ${ }^{39}$.

"De entre todos los mecanismos de control, el más evidente fue la censura directa, aunque resultaría mucho más decisiva la normativa sobre el doblaje obligatorio [...]"40.

Por lo que respecta a Garbancito de la Mancha, la censura tuvo una incidencia muy baja, que afectó básicamente a los grafismos de algunos personajes ${ }^{41}$. Y es que no se debe obviar que "la película va dirigida en todo momento a dar una enseñanza moralizante y a exaltar los valores de la época" ${ }^{42}$. No en vano, la producción incluye también un cierto mensaje político (su protagonista lucha, en nombre de Dios, contra los malvados, simbólicamente, una bruja y un gigante). Tampoco se debe olvidar que José $\mathrm{M}^{\mathrm{a}}$ Blay encargó el argumento para la película a Julián Pemartín, un escritor del Movimiento. Éste creó un cuento con el mismo título, Garbancito de la Mancha, en principio estructurado en 17 capítulos y que sería más tarde publicado como cuento por Saturnino Calleja ${ }^{43}$, el cual, "tuvo que ser adaptado por Moreno a las necesidades de la narrativa cinematográfica $[\ldots]^{\prime 44}$.

38 "Los poderes públicos anteriores a la Guerra Civil nunca habían definido una auténtica política cinematográfica, de tal manera que la voluntad intervencionista del nuevo régimen franquista iba a instaurarla poco menos que ex-novo [...]". MONTERDE, 2005, vol. 40: 187.

39 "A simple vista podría resultar algo paradójico este binomio, pero en realidad corresponde al permanente autoritarismo paternalista del franquismo, manifestado por su preferencia por coartar y debilitar las capacidades autónomas -en este caso de la industria cinematográfica- para así fortalecer su dependencia de las subvenciones y ayudas de diverso tipo.” Ibíd.: $187,188$.

40 Ibíd: 189.

41 Entre la bibliografía consultada, se halla una referencia a la censura: "El grafismo de algunos personajes fue cambiado por el realizador en el transcurso de la realización. Los cambios obedecen, a veces, a un motivo estético y otras al deseo de evitar cualquier problema con la fuerte censura de la época, como es el caso de que Peregrina, la [cabrita] fiel compañera de Garbancito, aparezca en los dibujos primitivos luciendo unas características ubres que fueron suprimidas posteriormente, quizá por pensar que era un espectáculo «demasiado fuerte» para los niños" MANZANERA, 1992: 27. Se trata de un caso similar al ocurrido unos diez años antes por la vaca Clarabella de los estudios Disney. Pero, en contrapartida, y acaso como guiño humorístico o irónico, las manos del personaje "Manazas", se asemejan, precisamente, a unas ubres...

42 M. Manzanera desarrolla esta idea y sigue diciendo: "El héroe tiene unas características netamente «españolas»; la intención de crear situaciones quijotescas está patente a lo largo de la narración, en la que el protagonista está adornado con las virtudes deseables en los niños de la época, lo cual quizá haya contribuido a envejecer el film" [Ibíd.: 28]. Y es que Garbancito de la Mancha, al igual que muchas de las películas de la época se utilizaban como "propaganda" y herramienta política del régimen de Franco (aunque también lo eran las películas de Disney respecto a los EE.UU.).

43 PEMARTÍN, 1943.

44 CANDEL CRESPO, 1993: 46. Según una anécdota, en la noche del estreno en Madrid (el 23.11.1945), no salió al escenario J. Pemartín (falangista, proalemán y antiamericano reconocido), a explicar las bondades del film, como estaba previsto, sino Arturo Moreno, ya que Hitler acababa de perder la guerra y el régimen de Franco precisaba acercar posiciones con urgencia con los vencedores. 

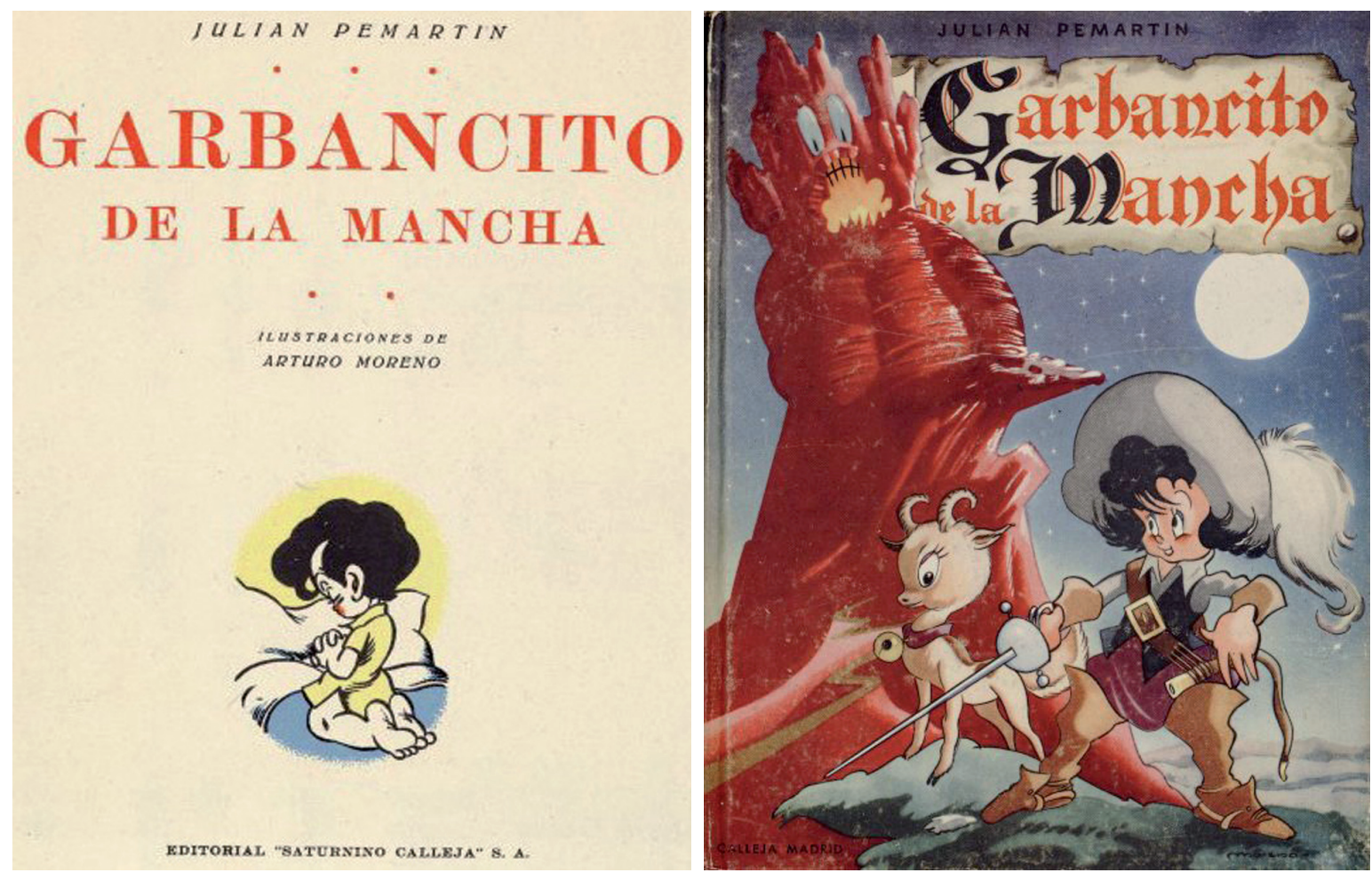

Figuras 6 y 7. Imágenes del cuento de Julián Pemartín editado por Saturnino Calleja

Entre las medidas proteccionistas que pretendían aumentar la producción, destaca la de premiar las producciones nacionales con permisos de importación, que pronto se convirtieron en un medio para obtener beneficios ${ }^{45}$ : las distribuidoras de la época subsistían gracias a los permisos de importación, “[...] que les aseguraban la asistencia masiva a sus salas, de un público que se sentía atraído especialmente por

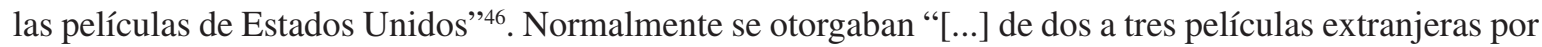
cada película realizada en España" ${ }^{47}$.

Así pues, la producción de Garbancito de la Mancha, que recoge también influencia de las producciones americanas (de Walt Disney, de los estudios Fleischer o de Ub Iwerks), es un fiel reflejo de esta situación:

"La causa que decidió a Balet y Blay a producir Garbancito de La Mancha no fue otra que la económica. Pensaron que este tipo de film les daría la oportunidad de obtener permisos para importar películas extranjeras (...)"48.

45 Véase ROLDÁN GARROTE, 2003: 16.

46 MANZANERA, 1992: 23-24.

47 CANDEL CRESPO, 1993: 49.

48 MANZANERA, 1992: 24. 
De hecho, los resultados obtenidos superaron con creces las expectativas iniciales, ya que:

"«Garbancito de la Mancha» fue considerada (y de hecho lo era) como una producción poco usual en la cinematografía española, y el Gobierno otorgó a la casa «Balet y Blay» ocho o nueve permisos de importación, pues la película había sido premiada por el Sindicato Nacional de Espectáculo y declarada de «Interés Nacional»" 49 .

Se le premió, pues, con una cantidad muy superior de lo que era habitual en películas de imagen real. Todo ello -la declaración de interés nacional y el dinero que se recaudara con la proyección de películas importadas americanas- unido al enorme éxito de taquilla y recaudación del propio film -recordemos que alcanzaría cifras insospechadas para la época en España: 33.628,33 €- ayudaría a amortizar el coste del film, que se acercó a los cuatro millones de pesetas $(!)^{50}$.

Probablemente, la obtención de estos galardones guarda relación con el hecho de que Julián Pemartín fuera escogido para elaborar el guión de la película.

Esta producción también contaba con el apoyo de los medios de comunicación de la época, por lo que el estreno fue precedido de una intensa campaña publicitaria en la prensa, en revistas y radio, recibiendo excelente aceptación y críticas. Así, en periódicos como La Vanguardia española o el ABC se dedicaron abundantes artículos y amplios espacios a Garbancito de la Mancha. También hacen lo propio publicaciones especializadas como Primer Plano ${ }^{51}$, que le ofrecen sus primeras páginas.

49 CANDEL CRESPO, 1993: 49.

50 MONTIEL, 2012, $\mathrm{N}^{\mathbf{0}}$ 2: 86

51 Revista cinematográfica que nace en 1940, una de las primeras publicaciones de la posguerra especializadas en cine, auspiciada por Falange Española. 


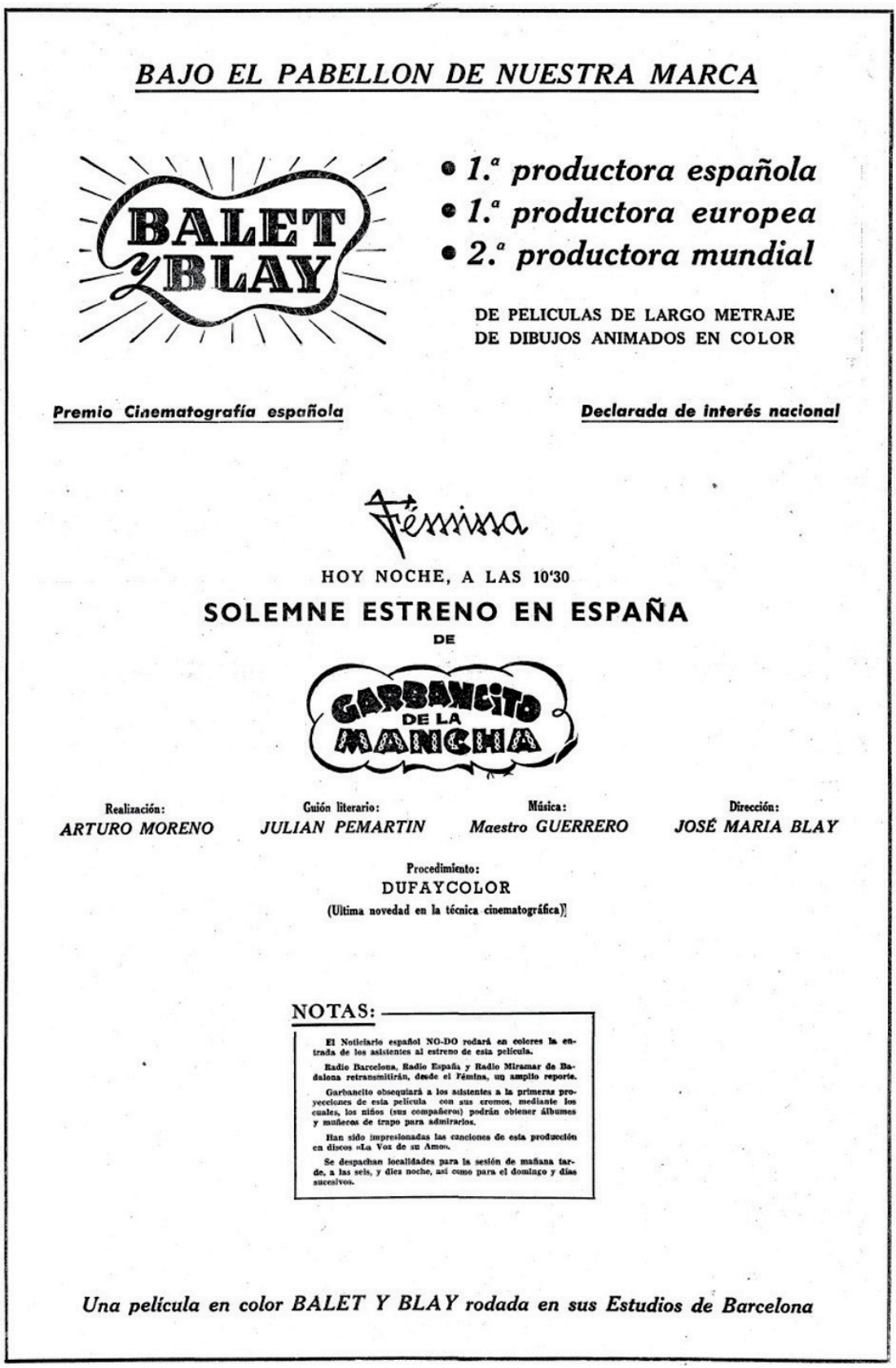

Figura 8. La Vanguardia española, 23.11.1945, p.11 
Incluso se comercializaron algunos pequeños productos publicitarios, como álbumes de cromos o muñecos de trapo, siguiendo unas técnicas de mercado hoy en día muy extendidas.
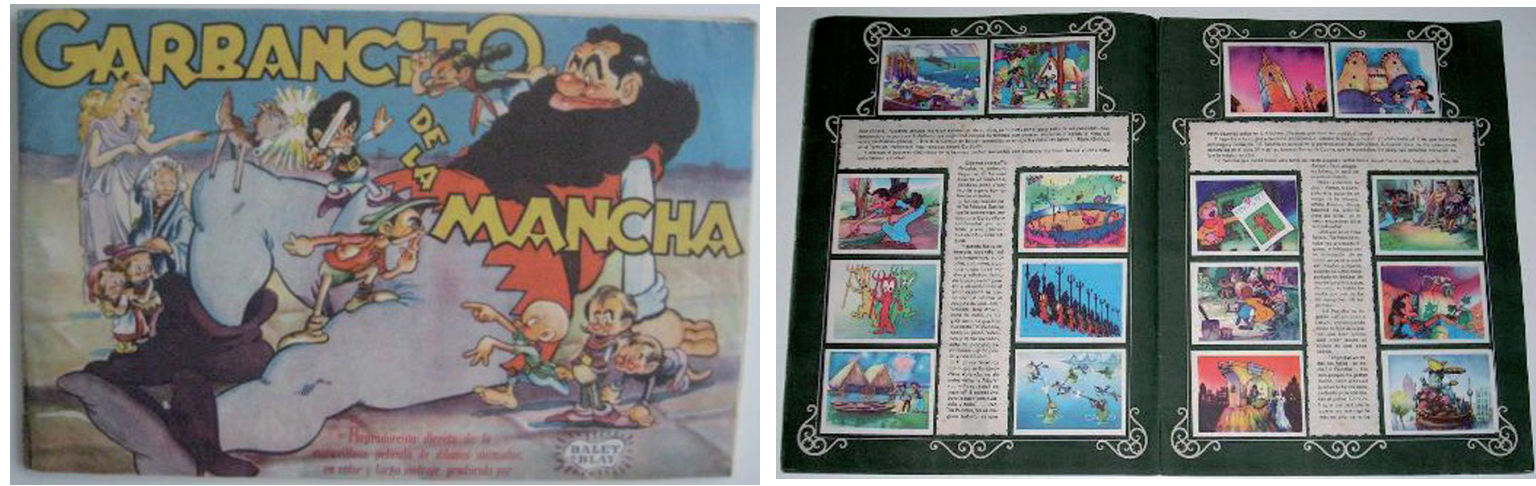

Figuras 9 y 10. Álbumes de cromos de Garbancito de la Mancha y Alegres vacaciones

Por tanto, podemos afirmar que la película reunía todos los ingredientes necesarios para alcanzar el éxito.

\section{EL COMPOSITOR: JACINTO GUERRERO}

Pero sin duda alguna, uno de los artífices del triunfo de Garbancito de la Mancha, fue Jacinto Guerrero $^{52}$. "Es evidente que, la elección del popular compositor lírico para componer la música del filme no fue casual" ${ }^{3}$. De hecho, llevó a cabo "[...] una labor muy aplaudida en la época y su nombre se utilizó claramente como reclamo" 54 .

52 Para más información sobre Jacinto Guerrero, consultar: GONZÁLEZ LAPUENTE, 1995. CORTIZO, 2000, vol. 6: 44-52.

53 ROLDÁN GARROTE, 2003: 116.

54 Ibíd: 116. 


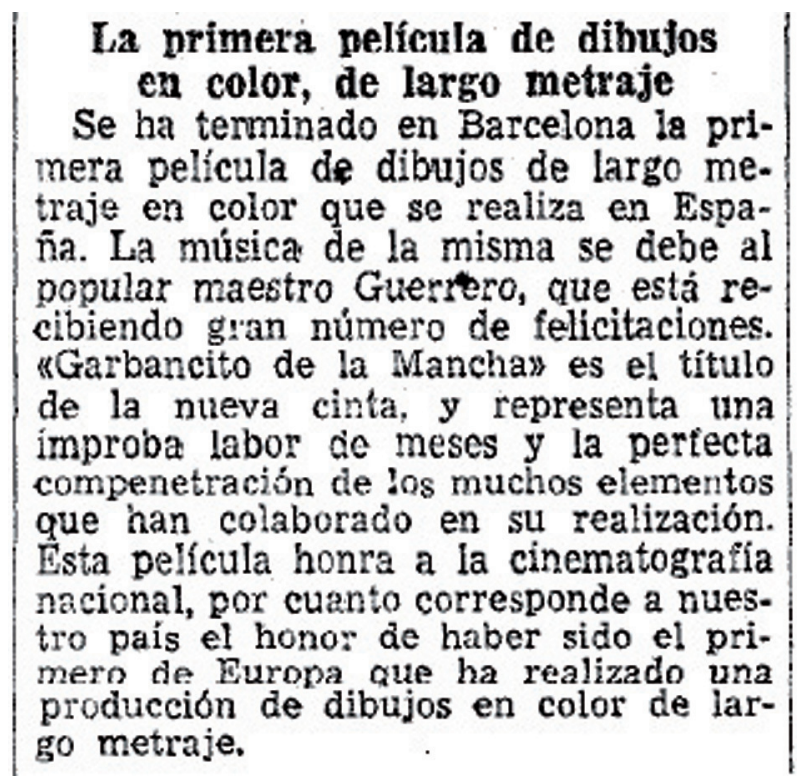

Figura 11. La Vanguardia española, 28.07.1945, p.8

En aquellas fechas, la composición de música cinematográfica ${ }^{55}$ suponía una pequeña parte de su producción musical pero, en cambio, era ya un consolidado compositor en el mundo de la escena que había descollado con zarzuelas como La alsaciana (1922), La montería (1922), Los gavilanes (1923), Don Quintín el amargao (1924), El huésped del Sevillano (1926), El sobre verde (1927), La orgía dorada (1928), Matierra (1928) o La rosa del azafrán (1930) ${ }^{56}$. El caso de Jacinto Guerrero no constituye un hecho aislado en el conjunto de los compositores de música para cine de la época, ya que en España no había una especialización, muy al contrario de lo que ocurría en los EE.UU. En su mayoría provenían

55 La ficha cinematográfica del maestro Guerrero nos muestra una clara experiencia en la composición de música en el cine. Antes de crear la partitura de Garbancito de la Mancha, ya había compuesto la música de los siguientes largometrajes: $L a$ canción del día (1930) de G. B. [George Berthold] Samuelson, Rumbo al Cairo (1935) de Benito Perojo, Currito de la Cruz (1936) de Fernando Delgado y El camino del amor (1943) de José María Castellví. También, participó en varios cortos: Do re mi fa sol la si o la vida privada de un tenor (1935) de Edgar Neville; Un anuncio y cinco cartas (1937), El fakir Rodríguez (1938), Letreros típicos (1938), Definiciones (1938), todos ellos dirigidos por el célebre Enrique Jardiel Poncela. Además, se llevaron al cine Don Quintín el Amargo (1935) de Luis Marquina; y dos versiones de El huésped del Sevillano, una en 1940, de Enrique del Campo, y otra en 1969, de Juan de Orduña. CORTIZO, 2000, vol. 6: 52. MANZANERA, 1992: 187. base de datos de películas calificadas del Ministerio de Educación, Cultura y Deporte:

http://www.mcu.es/bbddpeliculas/buscarDetallePeliculas.do?brscgi_DOCN=000002666\&brscgi_BCSID=1de603a8\& language=es\&prev_layout=bbddpeliculasResultado\&layout=bbddpeliculasDetalle [Acceso: 17.06.2005]. Véase también LLUÍS I FALCÓ, 1995a: 51-67.

56 Estos son los títulos de las zarzuelas más populares del compositor, pero la lista se convierte en interminable si se quiere recoger todas sus composiciones. También compone música para espectáculos de revista, anuncios de radio o canciones. (El presente trabajo intencionadamente no realiza un estudio más amplio sobre Jacinto Guerrero, pues no es su propósito desarrollar aspectos biográficos de figura tan conocida). 
de los espectáculos para la escena y poseían una formación técnica de calidad innegable ${ }^{57}$. Por otra parte, cabe añadir que la composición de música en los medios audiovisuales suscitará un especial interés por cuanto supone una incorporación a nuevas vías de expresión (nuevas tecnologías de la época). Jacinto Guerrero es un ejemplo de los muchos compositores que se han sentido atraídos por la composición para el cine: tal es el caso de George Auric (*1899; †1983), Benjamin Britten $(* 1913 ; \dagger 1976)$, Aaron Copland (*1900; †1990), Darius Milhaud (*1892; †1974), Georges Gershwin (*1898; †1937), Sergei Prokofiev (*1891; †1953), Camille Saint-Saëns $(* 1835 ; \dagger 1921)$, Dimitri Shostakovich $(* 1906 ; \dagger 1975)$, William Walton (*1902; †1983), Ralph Vaughan Williams (*1872; †1958), etc.

El propio compositor mostraba una enorme satisfacción por el resultado obtenido. Tanto es así que estimó “[...] que su partitura podía ser una obra de concierto, y por ello, como propaganda previa al estreno de la película, se programaron dos audiciones, una en Madrid y otra en Barcelona" ${ }^{58}$.

Además se editaron los cantables y temas más importantes de la película en disco (Compañía del Gramófono Odeón, Barcelona, 1945) ${ }^{59}$.

\section{LA PARTITURA}

La partitura autógrafa de J. Guerrero está depositada en el archivo del Instituto Complutense de Ciencias Musicales (ICCMU), sito en la sede central de la Sociedad General de Autores y Editores (calle Fernando VI, 4 - Madrid); a la cual he podido acceder por mediación de la Fundación "Jacinto e Inocencio Guerrero"60.

No hay duda alguna en que la mano de este documento se corresponde con la del maestro Guerrero, pues su firma se encuentra en numerosas ocasiones:

57 "El conjunto de músicos que trabajaron asiduamente para la gran pantalla durante la década de 1940, procedían en su mayoría del teatro musical y su formación técnica era de gran calidad. Una gran parte de compositores, por no decir su totalidad, tenían sus raíces en la música para la escena. Recordemos que en la década de los cuarenta todavía existía un fuerte fervor popular por la zarzuela y el género chico, así como por las piezas cortas de teatro como los entremeses. Nuestros compositores adoraban el teatro pero esto no daba suficiente para comer, por lo que comenzaron a vincularse al cine" ROLDÁN GARROTE, 2003: 157158. Y es que: Las particularidades asociadas a la técnica de composición fueron, rápidamente, asimiladas de los grandes maestros de Hollywood a través de sus películas. Tan sólo Joaquín Turina (*1882; †1902), y a cierta distancia, Jesús García Leoz (*1904; $\dagger 1953$ ), o Juan Durán Alemay (*1896; †1970), entre otros, mostraron interés por los aspectos de reflexión teórica asociados a la música de cine. Del resto, podemos afirmar, que se consideran a sí mismos, artesanos de un oficio: compositor de música de cine [Ibíd.: 159].

58 CANDEL CRESPO, 1993: 47.

59 Son tres discos de $78 \mathrm{rpm}$ de 6 minutos cada uno. Se pueden localizar entre los fondos de la Biblioteca Nacional de España y en la Biblioteca de Catalunya. Pero sin duda alguna, el registro más interesante es el existente en la Biblioteca Digital Hispánica ya que permite su audición a cualquier usuario de Internet simplemente accediendo a sus fondos digitalizados: http://bdh.bne.es/bnesearch/Search.do;jsessionid=4AF65CE3CC97E599F71772B23FC35F8F.

60 Como es sabido, la Fundación "Jacinto e Inocencio Guerrero" se creó en 1982 y se dedica a la organización de diversas actividades a nivel internacional relacionadas con los hermanos Guerrero. Entre ellas se puede destacar la convocatoria de Premios para alumnos del Real Conservatorio Superior de Música de Madrid y del Conservatorio Profesional "Jacinto Guerrero" de Toledo, el Concurso Internacional de Canto "Acisclo Fernández", el Concurso Internacional de Guitarra "Infanta Cristina", el Concurso Internacional de Piano "Fundación Guerrero" y el Premio "Fundación Guerrero" de Música. 


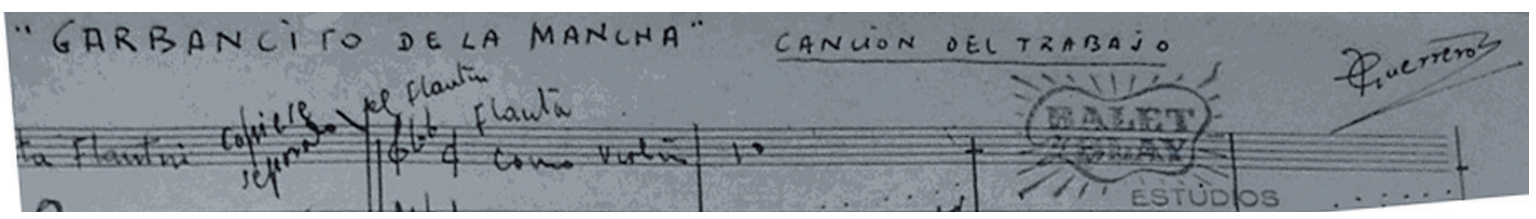

Figura 12. Partitura autógrafa de Jacinto Guerrero. Detalle. Inicio del tema del film la Canción del trabajo, sello de la productora Balet y Blay, y firma del compositor

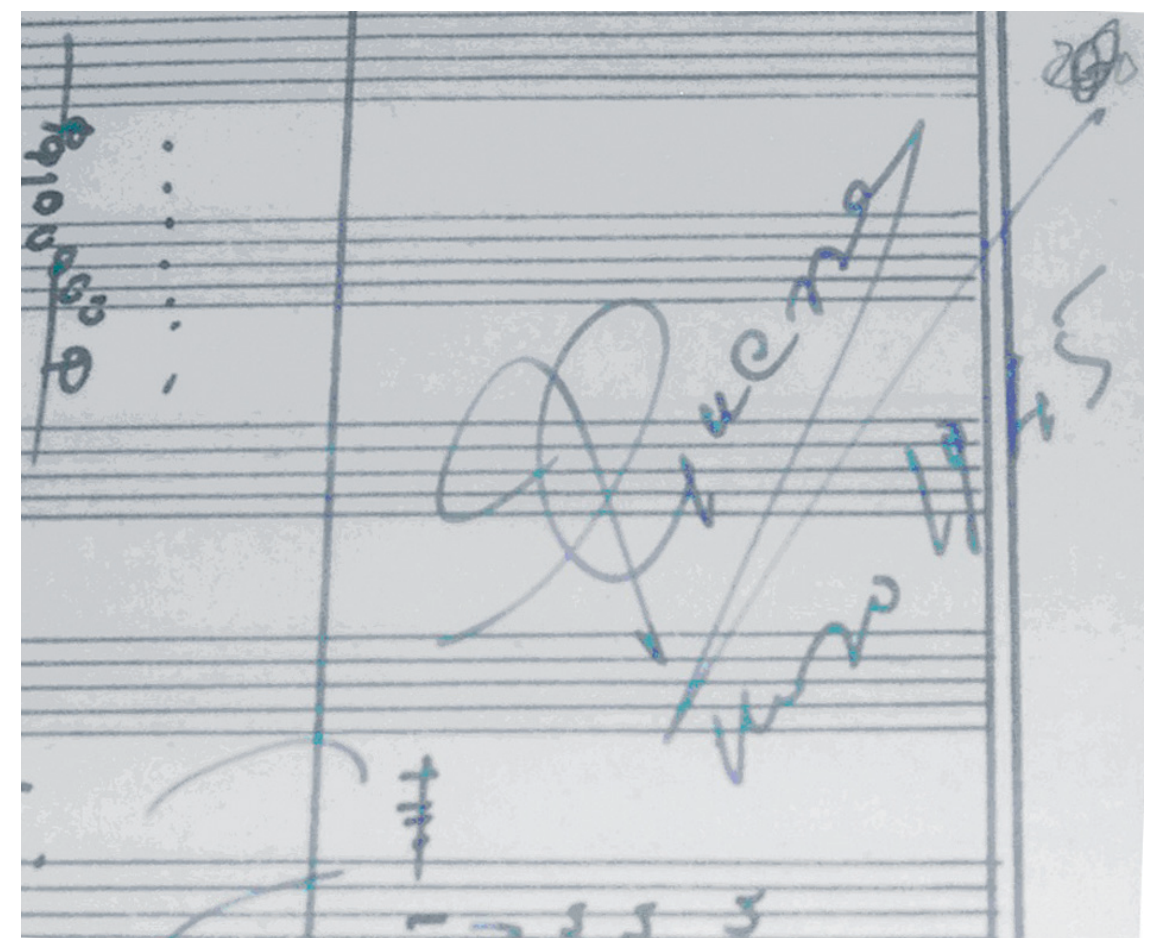

Figura 13. Partitura autógrafa de Jacinto Guerrero. Éxplicit, con firma y fecha de composición

Entre el material que se conserva, existe una partitura completa de la música de la película en versión orquestal, a excepción del séptimo rollo; y partichelas de la "Canción del trabajo" en versión orquestal, la "Canción de «los chopos»" en versión orquestal y la "Canción de «los chopos»" para cuarteto de voces masculinas y piano.

El maestro Guerrero numera la partitura por folios (también sigue el mismo procedimiento en las partichelas), situando los números en el margen superior derecho, y señala la correspondencia con las imágenes, escribiendo el número de rollo en su principio y marcando su final. 
Como es habitual en la composición de la música de cine, el compositor no siguió el orden estricto de la película para componer su música. Prueba de ello es la anotación del f. 16 v. del segundo rollo (fig. 14):

"Nota para el Sr. Andrada. Me faltan compases que tomar de una canción que tengo en Barcelona. [¿Dependo?] papel en los instrumentos para copiarlos yo mismo... Guerrero [rubricado]”.

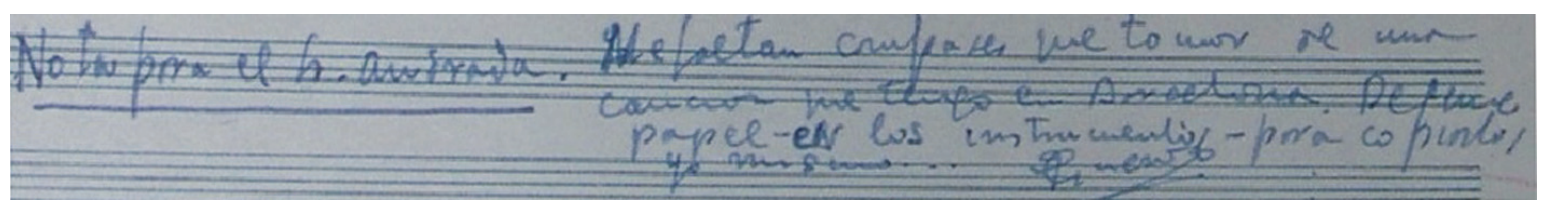

Figura 14. Segundo rollo, f. 16 v. Nota de Jacinto Guerrero

También refuerza esta idea que la numeración comience desde el principio en cada uno de los rollos y que siempre se escriba el título de la película.

Jacinto Guerrero numera los compases que se repetirán exactamente igual en otros momentos de la composición. De este modo, no vuelve a copiar de nuevo todo el fragmento sino que deja los compases en blanco y los numera según corresponda. En algunas ocasiones emplea letras "de ensayo" (A, B, C, etc.). Esta práctica será utilizada a lo largo de toda la partitura para ahorrar espacio y tiempo y da noticia de cuál es la técnica de la composición empleada, reutilización de ideas, estructuración y arquitectura de la obra o determinados pasajes, etc.

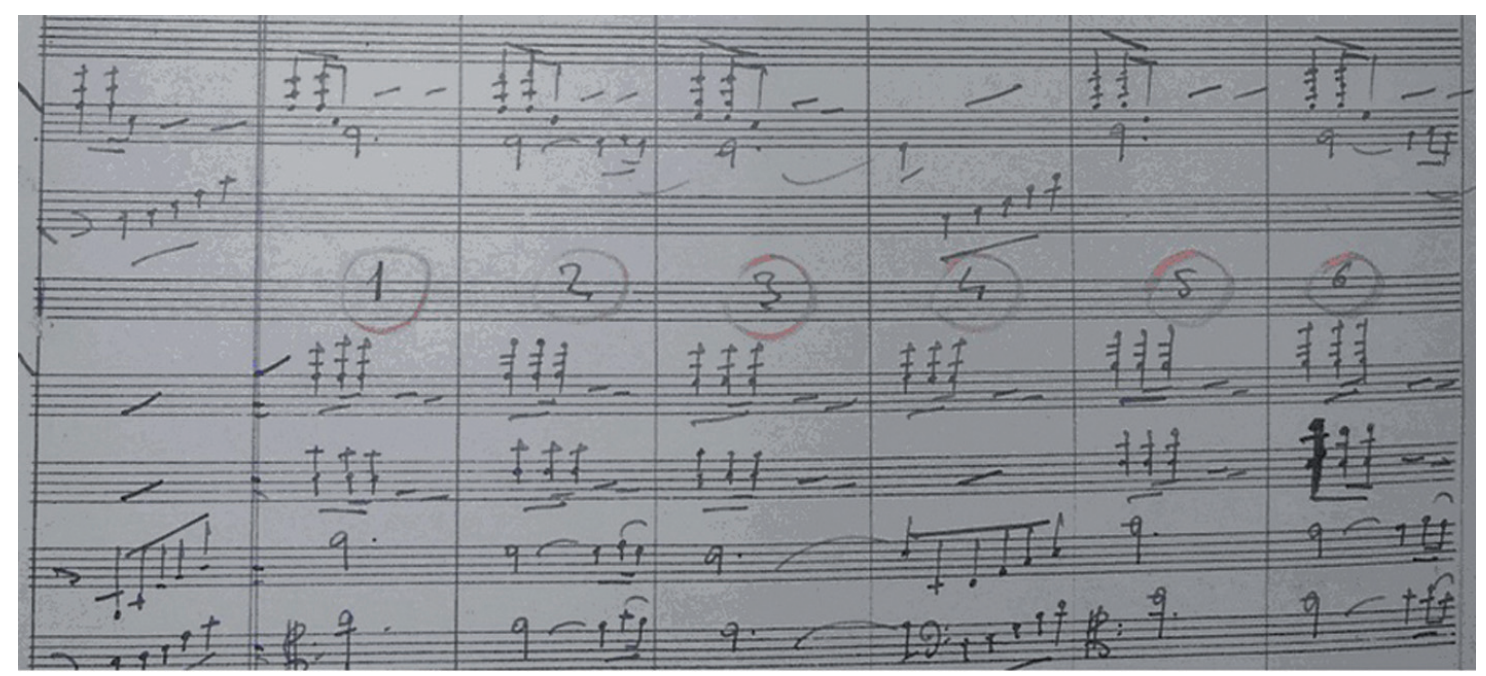

Figura 15. Ejemplo de numeración de compases 


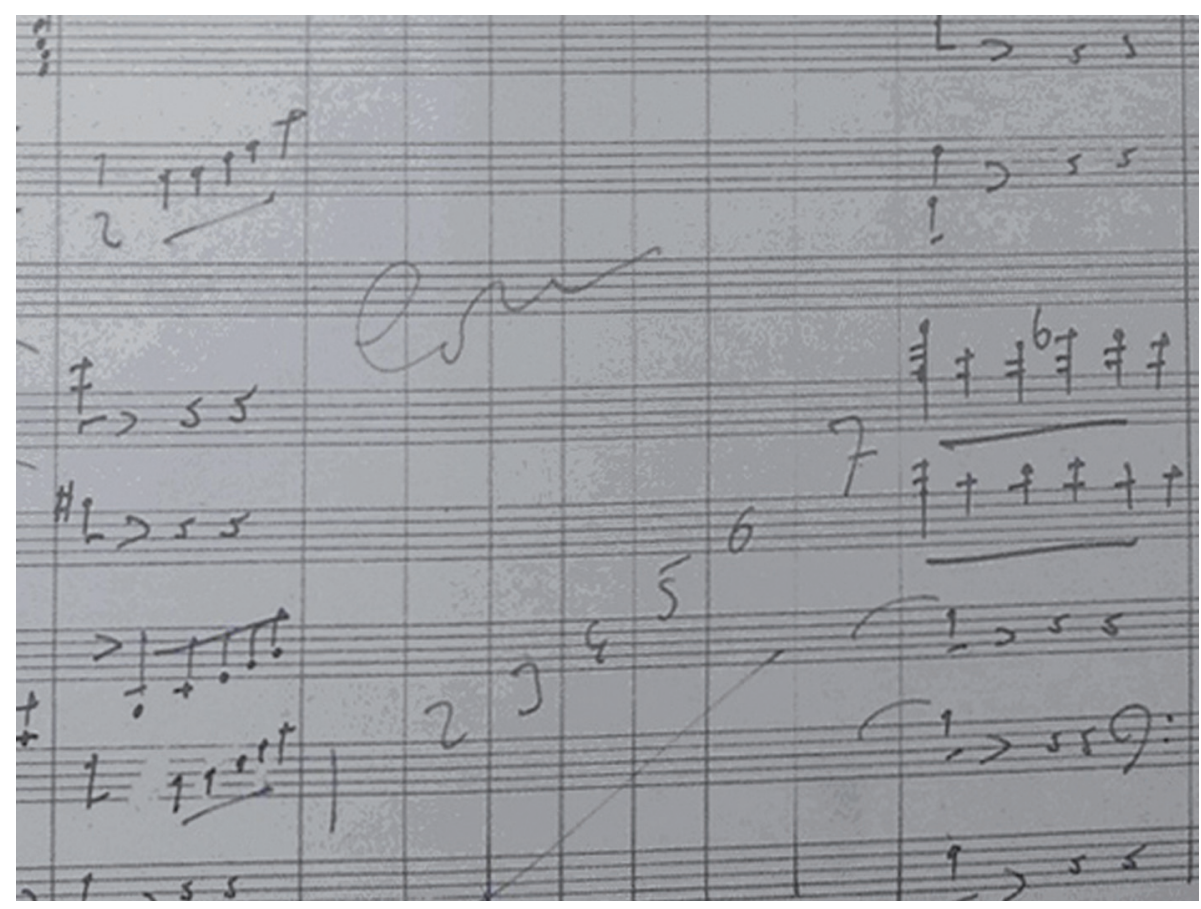

Figura 16. Fragmento de partitura en blanco con números que remiten a la figura 15

En cuanto a la calidad de la caligrafía, se puede afirmar que en general es buena aunque frecuentemente, el compositor elimina fragmentos de música sobre la partitura utilizando un trazo a modo de tachadura. Esto hará que la página tenga un aspecto algo desordenado y "sucio". Probablemente, se llevará a cabo esta práctica con la finalidad de ajustarse al tiempo de la imagen [sincronizar adecuadamente la música a la duración de la escena correspondiente]; incluso se realizan algunos cortes. No se puede obviar, por tanto, que es una obra concebida como "material de trabajo", eminentemente práctica, para usar/ grabar y desechar. Y es que "en «Garbancito de la Mancha» primero se hicieron los dibujos y después se hizo la banda sonora, adaptando la música. La única excepción fue la canción de Joaquín Bisbe, donde la animación se hizo sincronizada con la música" ${ }^{61}$. Precisamente, Joaquín Bisbe fue una pieza clave en la conformación musical de la película ${ }^{62}$.

61 CANDEL CRESPO, 1993: 47.

62 Como se ha señalado, un joven J. Bisbe llevó a cabo la labor de pianista repetidor a las órdenes de J. Guerrero. Bisbe tocaba al piano la partitura de Guerrero para cuadrar el tiempo de la música con el tiempo de las imágenes. En ocasiones se trataba de una partitura para piano y en otras, simplemente, eran unos cifrados e indicaciones de orquestación, a modo de guión. Tanto el maestro Guerrero como A. Moreno estaban muy satisfechos con la labor de J. Bisbe así que se pensó que éste compondría la música para una nueva escena que A. Moreno y A. Tosquellas habían decidido incluir y que no estaba en el guión inicial, "El sueño de Garbancito". En un principio J. Ma Blay dio el visto bueno y se procedió tanto a la creación de los dibujos como a la composición de la música. Pero finalmente, y debido al elevado incremento de tiempo y presupuesto que suponía hacer 6' más de película, Blay 
La grabación musical se efectuó en los estudios barceloneses de "La Voz de España", con una orquesta de 40 músicos dirigida por el maestro Guerrero. En cuanto a la sonorización de la película, el equipo de "La Voz de España" se trasladó hasta la granja "Cordellas" de Cerdanyola del Vallès, para grabar en vivo los sonidos propios de los animales domésticos, las aves de corral... ${ }^{63}$.

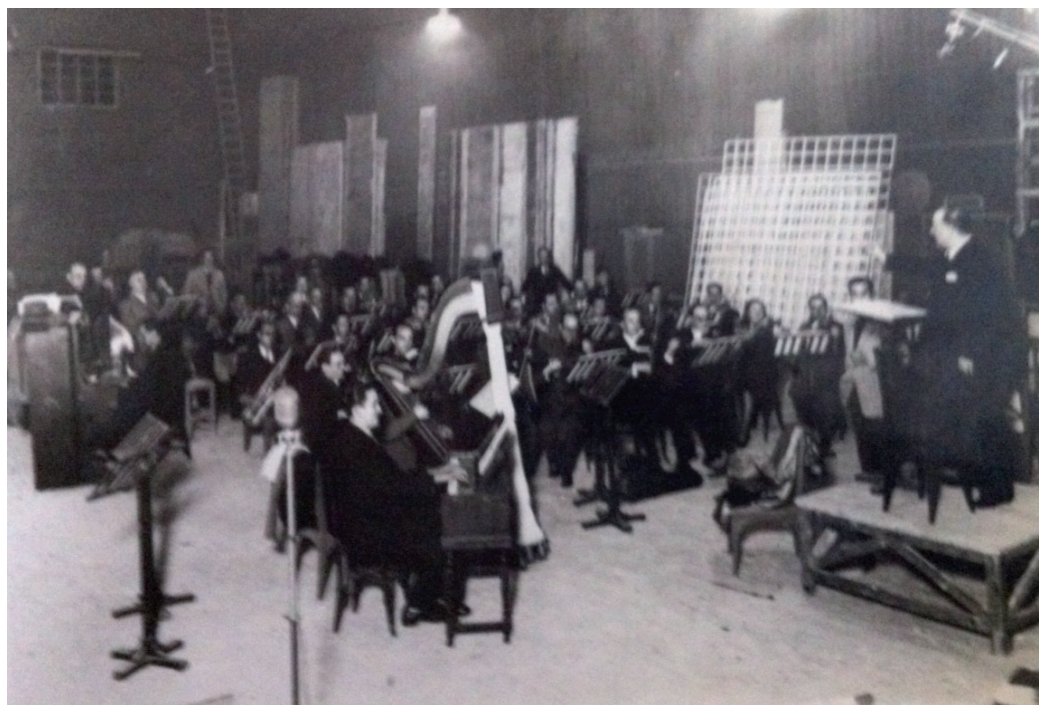

Figura 17. Orquesta dirigida por J. Guerrero en una de las grabaciones

\section{LA PELÍCULA EN 24 FOTOGRAMAS ${ }^{64}$}

decidió reducir esta escena a lo que hoy conocemos como el "Número [musical] de los gusanos". J. Bisbe tuvo que hacer hasta tres versiones diferentes de este número musical para que fuera del gusto de productor y algo similar ocurrió con la orquestación: en un principio Bisbe la concibió para big band, pero finalmente J. $\mathrm{M}^{\mathrm{a}}$ Blay decidió que participara toda la orquesta acompañando al cuarteto vocal "Orpheus".

63 CANDEL CRESPO, 1993: 47.

64 El largometraje presenta una clara influencia de la animación norteamericana, tanto en los grafismos como en el argumento o los personajes. La influencia de Walt Disney $(* 1901 ; \dagger 1966)$ está presente a lo largo del film: la escena en la que se muestra cómo Peregrina despierta a Garbancito, recuerda escenas de Blancanieves o Pinocho (fotograma 2); los guantes de la mosca son una copia de los guantes de Mickey Mouse (fotograma 3); el árbol en el que Garbancito y Peregrina se resguardan de una tormenta (este es el primer ataque de Tía Pelocha para evitar que ambos lleguen a la guarida del gigante -secuencia 17-) tiene notables semejanzas con los utilizados en el cortometraje de Flores y árboles (1932); la aparición del hada que salva a Garbancito de una muerte segura (fotograma 13) nos recuerda a numerosas apariciones de estos personajes en muchas de las películas de Disney, como por ejemplo en Pinocho (1940). Otras influencias se hacen evidentes en los personajes del gallo de la granja de Garbancito (fotograma 5), que nos recuerda al loro de Los tres caballeros (1945), de Disney y también a El pájaro loco [Woody Woodpecker] (1941) de Walter Lantz (*1900; †1994); o la cabrita Peregrina (fotograma 16) que tiene claras similitudes con los dibujos de Tom y Jerry (1941-1957) de Hanna \& Barbera (William Hanna Melrose $(* 1910 ; \nmid 2001)$ y Joseph Barbera $(* 1911 ; \nmid 2006)$. Pero sin duda alguna, la influencia más directa, es la vertida por la animación de los hermanos Fleischer: el gigante Caramanca (fotograma 9) guarda un gran parecido con Brutus, el enemigo de Popeye el Marino (1933); la niña, Kiriki (fotograma 8), se parece a Betty Boop (1931) con su pelo, sus ojos y sobre todo, la forma de su cara; muchos otros de los personajes del filme, pero en especial la fisonomía de los tres pillos (fotograma 4) -aunque también se les puede encontrar parecido con los enanitos de Blancanieves, de Disney- y la de la bruja Tía Pelocha (fotograma 9), tienen semejanzas con los personajes de Los viajes de Gulliver (1939). El final de la película, fotograma 24, sigue la tradición fílmica, de origen estadounidense del "Happy End". Por otra parte, tanto los grafismos como el argumento tienen un marcado carácter español: la panorámica del pueblo de la Mancha donde se sitúa la acción, 


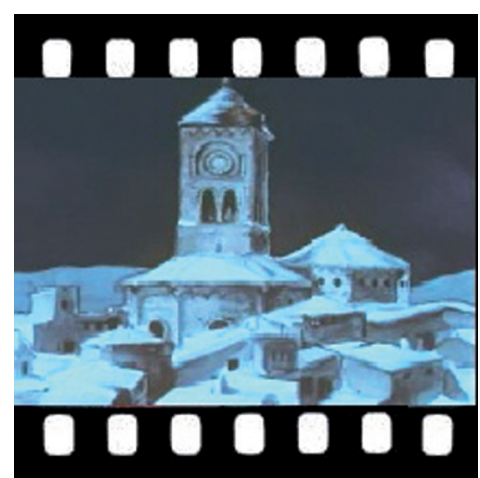

1. La voz narradora presenta la historia de Garbancito ${ }^{65}$ de la Mancha $^{66}$ y a sus protagonistas.

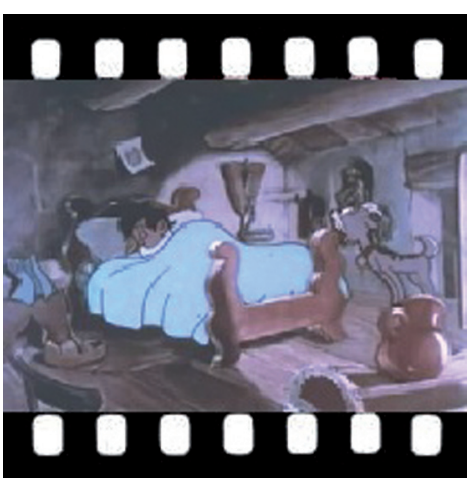

2. Garbancito vive en una granja con su cabrita Peregrina ${ }^{67}$. Todos los días se levanta temprano para hacer sus tareas ${ }^{68}$.

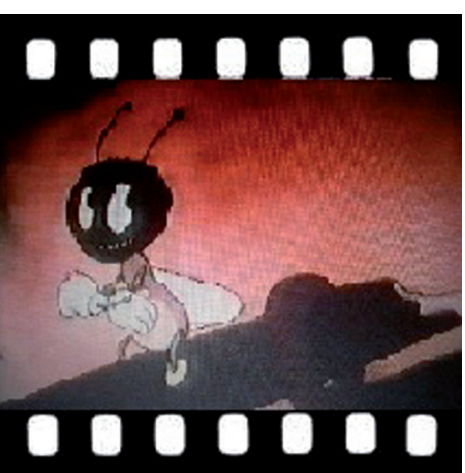

3. Mientras se prepara el almuerzo, una mosca hambrienta le causa problemas.

un pueblo típicamente español (manchego), con su campanario y sus cigüeñas (fotograma 1); el momento en el que los tres pillos son embestidos por un toro que pasta por el bosque (fotograma 7), que corre atraído por el rojo de la tela que envuelve los quesos de Garbancito (pensamos en los Sanfermines o "els bous al carrer"; y es evidente que en Garbancito de la Mancha era necesaria la inclusión de alguna escena taurina dado el gran éxito del corto El toro Ferdinando (Ferdinand the Bull, Dick Rickard, 1938), de Walt Disney, que le valió un óscar en 1938, y que posiblemente se conociera en España (sólo data de siete años antes de la presente película), y con el que guarda cierta similitud; en esta persecución se ve inmiscuido un comerciante que pasaba por allí a lomos de su burro (animal genuinamente español: Sancho Panza y su burro Rucio); la secuencia de la "Canción de «los chopos» (fotograma 8), donde los cipreses, con su copa alargada, nos recuerdan a los capuchinos de la Semana Santa (que, a menudo, aterrorizan a los niños, y que estarían en el imaginario de la época, de cualquier niño español -nueva alusión religiosa-.; la aparición de molinos de viento en diversas ocasiones a lo largo de la película (secuencia 18, 19 y 24); la presencia de los dibujantes caricaturizados en la escena en la que el alcalde del pueblo le concede la entrada en la Orden de los matagigantes (tradición del cómic y del tebeo español) -fotograma 23-. Y como ejemplo de una magistral combinación de la influencia americana y un sabor genuinamente español, está la secuencia en la que el ratón intenta burlar al gato para comerse los quesos de Garbancito: el ratón se transforma en un torero (fotograma 6), convirtiendo sus orejas en una montera y poniéndose la punta de su rabito por coleta, con capote incluido ("corrida de toros"). Esta escena resulta innecesaria para el desarrollo de la acción ya que el único dato importante es que Garbancito se dirige al pueblo a vender sus quesos. A pesar de ello, se introduce como complemento, consiguiendo que sea enriquecedora, divertida y de gran valor en el conjunto del film. Resulta evidente que sigue la estética de los dibujos animados americanos en los que las peleas entre dos animales son una constante: Silvestre y Piolín, el Coyote y Correcaminos, etc. e incluso encontramos un gato y un ratón cuyas peleas adquirieron fama mundial: Tom y Jerry. Muchos son los ejemplos posteriores entre los que destaca Speedy González (personaje creado por la Warner en 1953) y el gato Silvestre; o los ratones Pixie y Dixie y el gato andaluz, Jinks (serie de animación creada para la televisión en1958 por Hanna \& Barbera). LUCCI, 2005: 63, 66, 68, 72, 73. MANZANERA, $1992: 28$.

65 Garbancito es el protagonista de la historia, personaje que nace de la combinación de Garbancito (personaje infantil del cuento popular que se titula de igual forma) y la figura de Don Quijote de la Mancha (hidalgo español de una de las obras más relevantes de la literatura). Así surge un nuevo personaje, híbrido, niño y caballero; divertido, pero héroe, etc. Un ejemplo a seguir con el que los niños de la época pueden identificarse. "El héroe tiene unas características netamente «españolas», la intención de crear situaciones quijotescas está patente a lo largo de la narración [...]”.MANZANERA, 1992: 28.

66 Garbancito de la Mancha se sitúa en un tiempo indefinido, posiblemente una idílica (utópica, perdida) España imperial, al igual que El Quijote: "No hay ninguna mención específica, pero sí referencias que permiten situar los hechos en un tiempo determinado. No transcurre ni en el futuro [...] ni en el presente. Ni siquiera en una época cercana o inmediata. El cuento se inicia con una clara referencia al pasado [...].Y sobre todo, el estilo, que calificaríamos de «castellano viejo», el vocabulario y la búsqueda intencionada de analogías y empleo de expresiones de $E l$ Quijote. Todo contribuye a situar los acontecimientos en esa España Imperial que constituye el paradigma del nacional-catolicismo, o al menos, a centrar el tiempo de la acción en torno a dicho período". MANZANERA y VIÑAO, 6, (enero-diciembre, 1987): 145-146.

67 La cabrita comparte protagonismo con Garbancito. Le acompaña en su hazaña y le presta ayuda en numerosas ocasiones. Las hadas le otorgan el poder de que se le iluminen los cuernos cada vez que su dueño esté en peligro y es ésta quien evita que la bruja mate a Garbancito y quien acabará con ella. Esta pareja protagonista nos recuerda a la formada por Mickey y Pluto (Pluto debuta en The Moose Hunt, 1931). Al igual que Pluto, Peregrina no habla pero consigue comunicar sus emociones y sentimientos a través de movimientos (demanda una gran exigencia en la animación).

68 "Se exalta la [entonces vigente en España] idea del autoabastecimiento: él cuida su huerta y sus animales, que le dan para subsistir". MANZANERA, 1992: 28. 


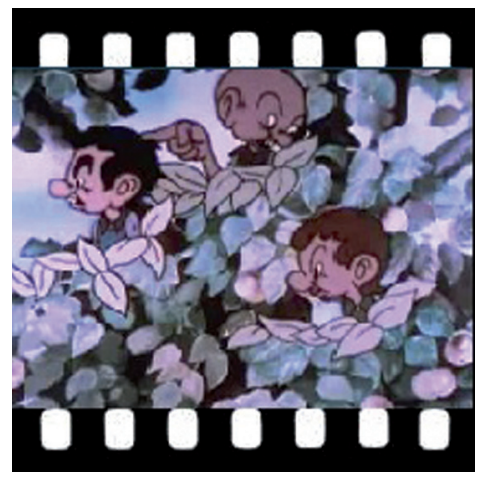

4. Cada día, Garbancito cultiva la tierra y realiza sus labores con alegría. Mientras, Manazas, Pajarón y Zepe ${ }^{69}$ se burlan de él ${ }^{70}$.

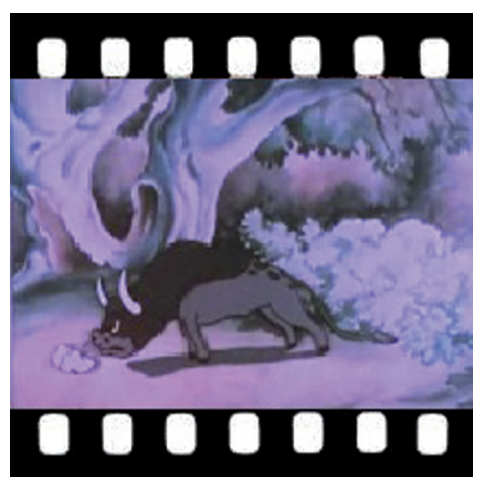

7. Garbancito se dirige al pueblo para vender los quesos, pero en el camino los pillos intentan robárselos, sin éxito. Todo, gracias al ratón y a un toro que les persigue.

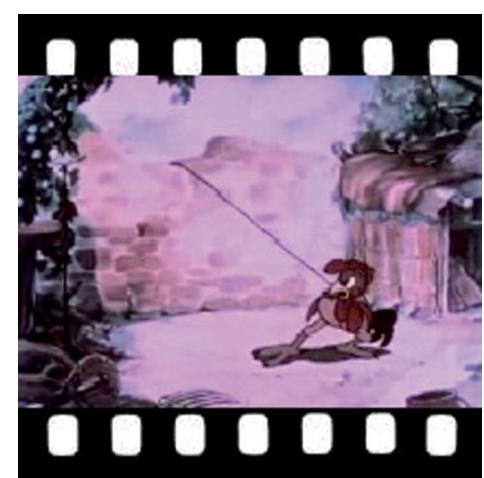

5. Los tres pillos intentan robarle el gallo a Garbancito sin conseguirlo y terminan a remojo en el río para evitar las picaduras de unas abejas.

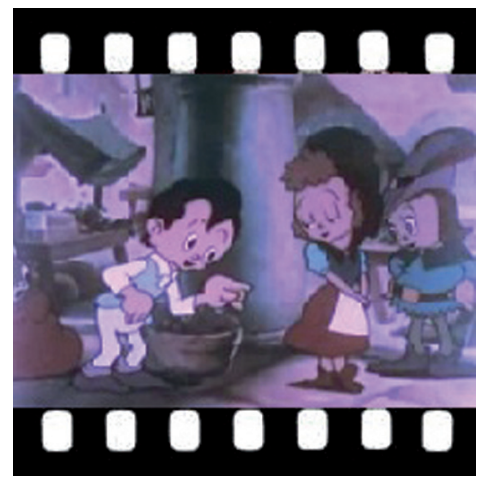

8. Ya en el pueblo, Garbancito habla con sus amigos, Kiriki y Chirili: están muy asustados por los rumores sobre el gigante Caramanca. La bruja Tía Pelocha ${ }^{71}$ amenaza a los niños.

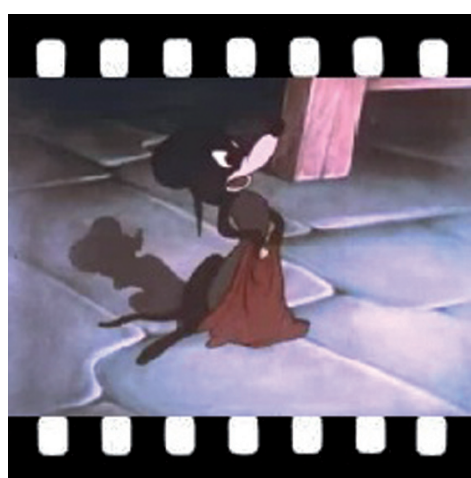

6. Un ratón intenta burlar al gato y comerse los quesos que elabora Garbancito. Al final queda atrapado en el interior de un queso.

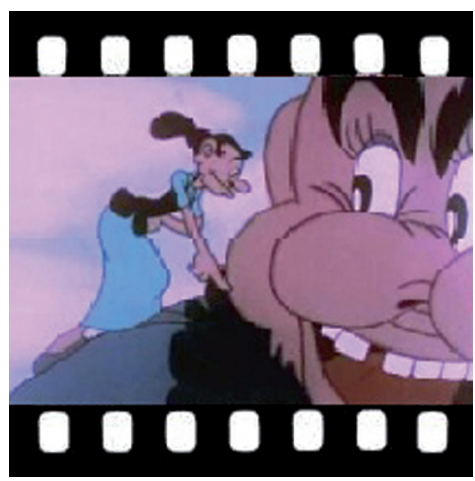

9. La bruja tiene que huir, pero jura vengarse de Garbancito. Así que vuelve con Caramanca, para que éste devore a las gentes del pueblo y secuestre a Kiriki y Chirili.

69 Estos tres niños son perezosos, ladrones, holgazanes, y envidian las cualidades y méritos del protagonista. Cometen numerosas travesuras e incluso llegan a propinar una paliza a Garbancito, la cual le deja moribundo. Son personajes antagonistas de Garbancito, pero se situarían en un primer nivel, oponiéndose al Garbancito niño.

70 M. Manzanera titula la secuencia en que los tres pillos comenten sus malas acciones con el nombre de "Las bernardinas" y aclara en una nota a pie de página que "hemos titulado así esta escena por su analogía con situaciones semejantes descritas en la literatura, especialmente por Lope de Rueda, que son conocidas con este nombre". MANZANERA y VIÑNAO, 6, (enerodiciembre, 1987): 130.

71 En cualquier cuento es absolutamente necesaria la presencia de personajes que encarnen el mal. El gigante Caramanca es el antagonista de Garbancito: lo situaremos en un segundo nivel ya que se opone a Garbancito héroe. Como es habitual, el antagonista tiene otros personajes a su servicio; éste es el caso de la bruja Tía Pelocha. Caramanca no posee ningún poder sobrenatural, únicamente las cualidades que le otorga su condición de gigante. En cambio, la Tía Pelocha, como cualquier bruja, tiene abundantes poderes, controla la magia y tiene numerosos subordinados que le prestan ayuda. 


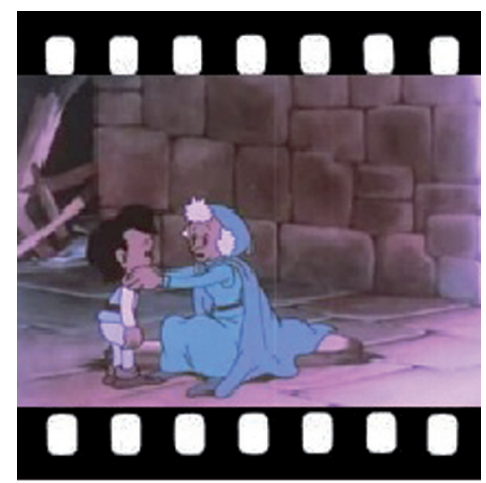

10. Garbancito consuela a la madre de los niños y se compromete a rescatarlos ${ }^{72}$.

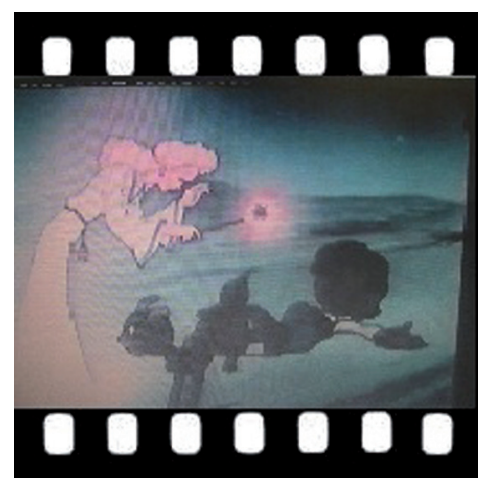

13. De repente, aparece un hada $^{73}$ que le cura, le nombra caballero y le concede el poder de convertirse en garbanzo.

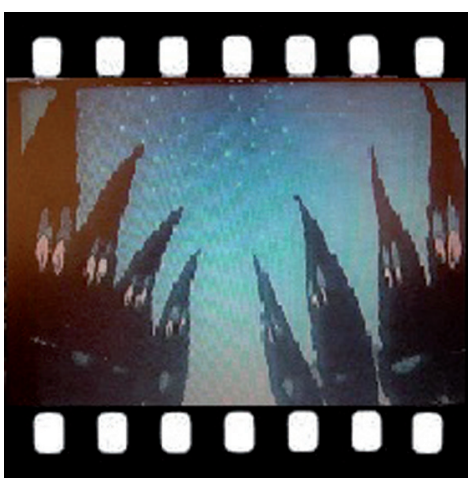

11. Asustado, el niño se adentra en el bosque para comenzar su búsqueda. Los árboles cobran vida y le cantan una canción.

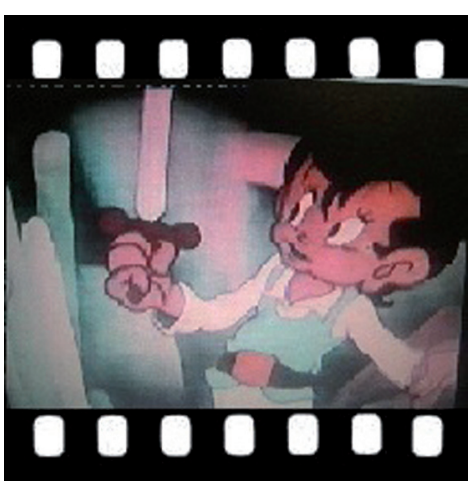

14. El niño vuelve a la granja, fabrica una espada mágica ${ }^{74}$ y utiliza el conjuro, pasando algunos apuros ${ }^{75}$.

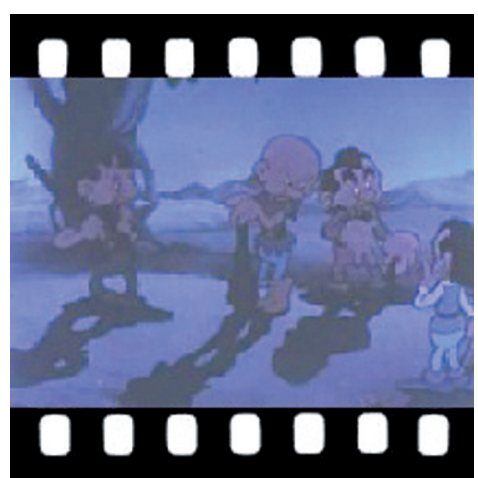

12. En el camino, Garbancito se encuentra de nuevo con los tres pillos, que le dan una paliza y le abandonan malherido.

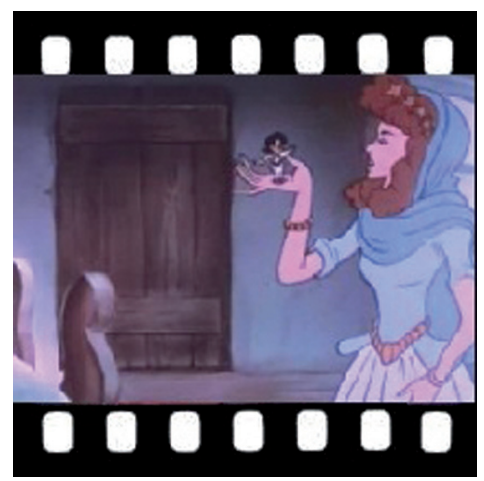

15. Otra hada acude en su ayuda y le lleva al palacio, donde están sus otras hermanas.

72 Éste es un momento clave en la narración: el protagonista, ante el sufrimiento de la madre de sus amigos, se compromete a rescatarlos de las garras del gigante, mostrando un valor caballeresco.

73 Resulta curioso ver cómo se entremezclan con gran coherencia los personajes de naturaleza fantástica y la figura de Dios: las hadas serían una especie de ángeles de los que Éste se sirve para guiar a Garbancito.

74 "Su espada se asemeja a la de los grandes personajes, es forjada por su dueño, como hace Sigfrido y tiene unas claras analogías con Excalibur, la espada del Rey Arturo; Colada y Tizona del Cid o la espada del Príncipe Valiente. Se utiliza como un claro recurso épico". MANZANERA, 1992: 28.

$75 \mathrm{El}$ tono aleccionador y moralizante siempre está presente: "Garbancito no es sólo un héroe bueno, sino que es profundamente religioso, reza al levantarse y las alusiones a la Providencia son continuas [...] Abundan los rasgos paternalistas. Se critica la desobediencia, la falta de responsabilidad [...]". Ibíd. 


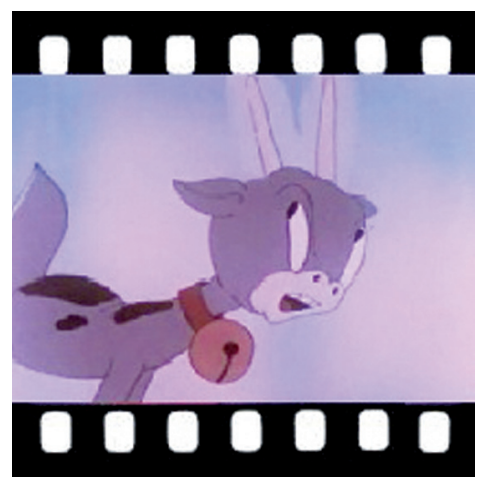

16. Allí, le perdonan su error y le otorgan nuevos poderes ${ }^{76}$, tanto a él como a Peregrina.

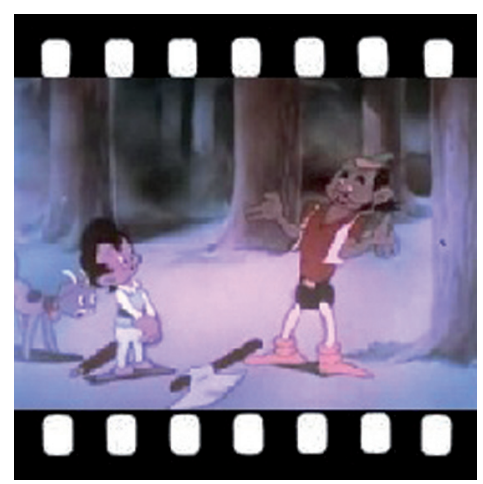

17. El niño prosigue con su misión, que se ve retrasada por varios incidentes y peligros, de los que siempre sale airoso.

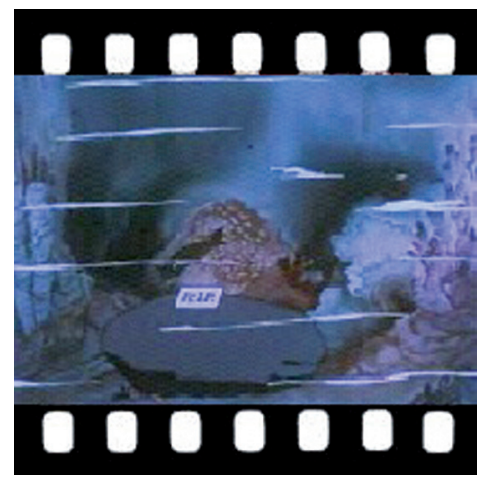

20. La bruja intenta aplastar al niño con una roca, pero con la intervención de Peregrina, la bruja acaba en el fondo del mar.

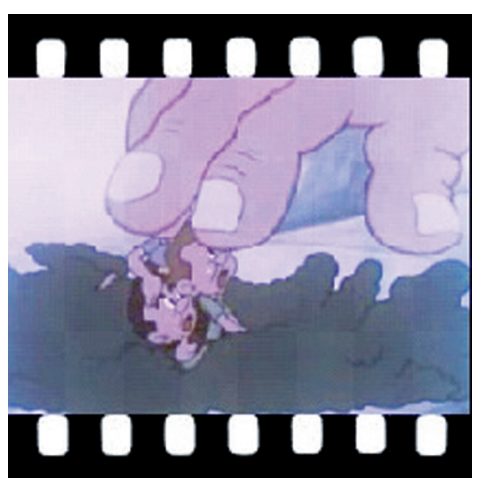

18. Mientras, los tres pillos se ven arrastrados por el viento hasta el castillo de Caramanca, donde éste les captura.

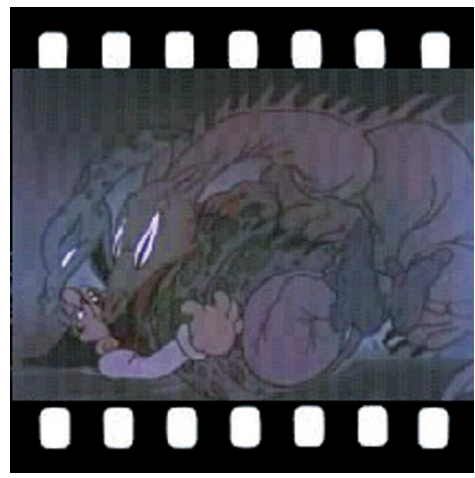

21. Garbancito, gracias a sus poderes, consigue derrotar al gigante, que muere devorado por sus propios monstruos ${ }^{77}$.

76 Garbancito ha cambiado, ya no es niño, ni granjero. Ahora es un caballero con espada, un héroe.

77 El desenlace final, con la muerte de los dos personajes malvados, la bruja y el gigante, sigue la tradición de los dibujos animados de Disney, donde el "malo" muere sin obtener la redención. 


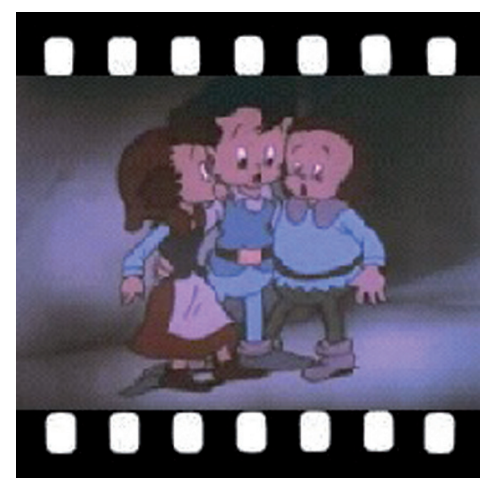

22. Garbancito rescata a sus amigos y a los tres pillos, que se disculpan y redimen sus culpas ${ }^{78}$.

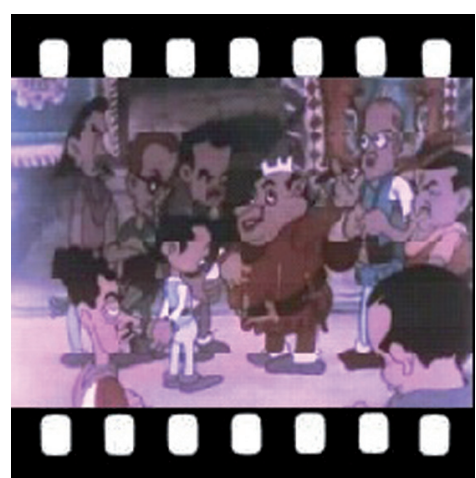

23. Ya en el pueblo, un gentío vitorea al héroe, que es premiado con el ingreso en la Orden de los matagigantes.

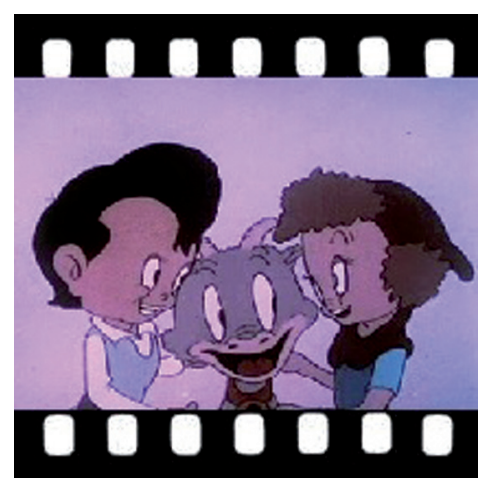

24. La historia termina felizmente, con Garbancito y Kiriki enamorados.

\section{ANÁLISIS DE LA MÚSICA DE LA PELÍCULA}

Para el análisis, he tenido presente una condición imprescindible: considerar la música como parte integrante del film. No es posible desligar el análisis musical de la narración, ni del resto de elementos que conforman el texto. En este sentido, adoptaré el concepto de "contrato audiovisual" postulado por M. Chion $^{79}$, de manera que se plantee un análisis conjunto de música e imagen, en donde la música es la protagonista, aunque condicionada por las múltiples interrelaciones que mantiene con el resto de elementos.

78 En contraposición a lo que le sucede a la bruja y al gigante, los tres pillos consiguen salvarse porque se arrepienten de sus fechorías y le piden perdón a Garbancito (importancia del arrepentimiento para obtener el perdón). Algunos querrán ver, en este desenlace final, connotaciones políticas, en las que los personajes se identificarían con los dos bandos de la Guerra Civil española. Por supuesto, Garbancito, el niño héroe, valeroso, representaría a la España nacional que, por petición de la "bondadosa madre", se enfrentará a Caramanca y a Tía Pelocha, y rescatará a los niños. En el lado opuesto, todos los personajes que ocupan el papel de "malos" simbolizarían la España republicana (la bruja, el gigante y también los tres pillos). Así, se identificarían dos categorías dentro de éstos últimos, los tres pillos, que se arrepienten (aunque son presentados como niños que cometen fechorías, no se debe olvidar que su maldad es importante pues le dan una paliza de muerte a Garbancito) se identificarían con los republicanos que se "convierten" y asumen las creencias y doctrina franquistas, encontrando su salvación; y los "malos, malísimos", aquéllos que no se someten y luchan hasta el final, encontrando su único destino, la muerte. Así Garbancito de la Mancha posee alguno de los rasgos que caracterizan lo que G. Sevilla ha denominado "modelo cruzada": el buen vasallo (Garbancito), militarismo (el rescate de sus amigos constituye una acción bélica), la patria (la bondadosa madre). [Véase: SEVILLA LLISTERRI, 2007]. Este punto de vista es muy interesante, pero hay que tener en cuenta que cualquier película de Walt Disney encajaría perfectamente en este rol. Aunque no se debe perder de vista que la película está basada en el argumento de J. Pemartín, cercano al régimen franquista, como ya se ha comentado. Y además, como cualquier cuento infantil, aparte de entretener, pretende transmitir unos valores, en este caso, obviamente más próximos al régimen dictatorial en el poder. Resulta evidente, pues, que la lectura política es cierta y plausible, pero mucho más verosímil se presenta la visión religiosa: se trata de una película "moralizante", con directrices claramente nacional-católicas. MANZANERA, 1992: 28.

79 Véase CHION, 1993: 12. 


\section{Análisis tímbrico: la orquestación}

El tratamiento de la orquestación refleja el estilo personal de J. Guerrero, al que hay que sumar la atención prestada hacia las nuevas necesidades que plantea la creación de música para animación. Así:

"[...] se hace presente la sonoridad orquestal que Guerrero hace propia: duplicaciones continuas de la melodía, construcción de una sonoridad basada en yuxtaposiciones y adiciones instrumentales, y texturas armónicas ligeras en el acompañamiento. La orquestación funciona con bloques instrumentales bien definidos: instrumentos que llevan la melodía frente a instrumentos reducidos a mero soporte armónico. Las melodías del maestro son siempre interpretadas al unísono (o dobladas a la octava) por la cuerda y el viento-madera. Toda su concepción orquestal estará siempre supeditada a la melodía: frases arqueadas, fáciles de retener en la memoria, de enorme lirismo e inspiradas muchas veces en esquemas de melodía populares. Su interés por las melodías tradicionales manchegas es un hecho demostrado"80.

La plantilla orquestal que escoge el compositor es la siguiente: voces: Soprano, primer Tenor, segundo Tenor, Barítono y Bajo; cuerda: violines primeros, violines segundos, violas, violonchelos y contrabajos; viento-madera: flautín, flauta, oboe, clarinetes (en Si bemol), fagot; saxo alto (en Mi bemol), saxo tenor (en Si bemol), viento-metal: trompas (en Fa), trompetas (en Do), trombones, trombón bajo (tuba); percusión: timbales, batería, bombo y plato, celesta, campana, lira, cascabeles, tamboril, bloc, pandereta, caja, silbido; arpa, piano. Es una plantilla amplia, por lo que necesitará para su realización una orquesta sinfónica.

Los instrumentos que gozan de mayor protagonismo son los de viento ${ }^{81}$. No se debe olvidar que Garbancito de la Mancha es una película que tiene carácter de historia épica, por lo que parece lógica la utilización de estos instrumentos, asociados sobre todo a momentos de peligro, lucha o valor (música de llamada) ${ }^{82}$. También posee un papel preponderante la percusión, que cuenta con la participación de gran cantidad de instrumentos (timbales, batería, bombo y plato, celesta, campana, lira, cascabeles, tamboril, bloc, pandero, silbido, pandereta, caja, etc.) ya que son versátiles para la realización de los numerosos "efectos especiales" de audio de los que precisa una película, atractiva, de estas características ${ }^{83}$. Otros medios instrumentales reseñables son las flautas, flautines y clarinetes, que con su timbre característi-

80 CORTIZO, 2000, vol. 6: 46.

81 Importancia de los instrumentos que conforman las bandas de música.

82 Se utiliza este término para referirse a toda aquella música que posee la facultad de "llamar la atención del oyente" y crear una situación de expectación. Suele ser una música breve, con un ritmo marcado que busca la repetición de motivos y con una línea melódica ascendente. Podemos buscar sus orígenes en la música que se tocaba tanto en las fanfarrias a cargo de ministriles como durante las cacerías. También encontramos evidencias de su utilización en la música culta (Monteverdi, Händel, Haydn, Beethoven, Mahler...). Actualmente conservamos algunos casos donde se usa como pueden ser la música de clarín que anuncia la salida del toro en las corridas, el toque de diana en el ámbito militar o la música que se utiliza para abrir y cerrar los anuncios en los supermercados...

83 El silbido por ejemplo, ha sido un recurso utilizado a menudo en películas de animación. Así por ejemplo, aparece en la célebre canción entonada por la protagonista de Blancanieves y los siete enanitos (Snow White and the seven dwarf, David Hand, 1937) mientras barre la casita de los siete enanitos, "Silbando al trabajar" ("Whistle while you work", con música de Frank Churchill y Leigh Harline), o en la canción "Dame un silbidito" ("Give a little whistle", con música de Jiminy Cricket) que entona Pepito Grillo en Pinocho (Pinocchio, Ben Sharpsteen y Hamilton Luske, 1940). 


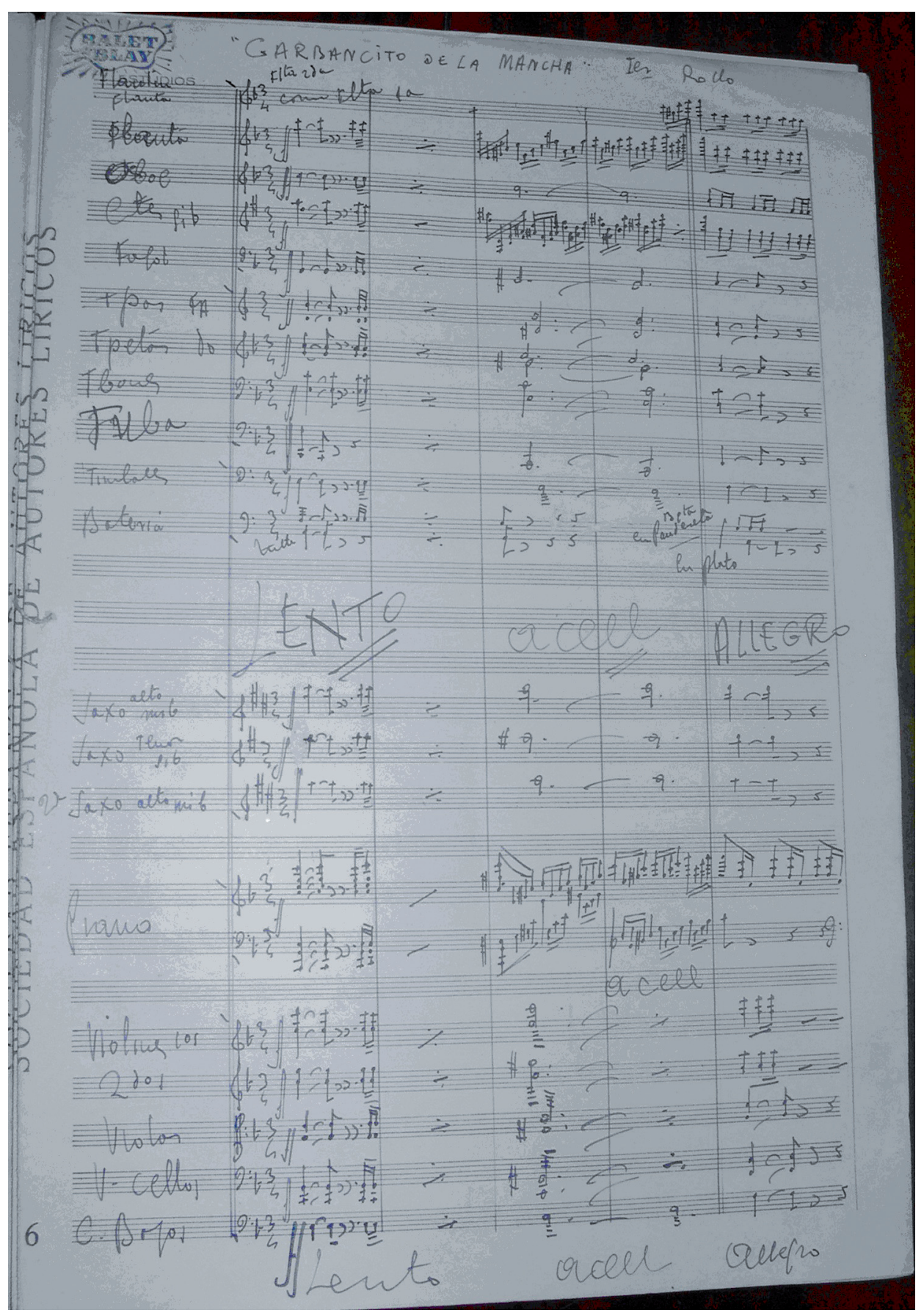

Figura 18. Detalle de la plantilla orquestal, primer rollo de Garbancito de la Mancha. Partitura autógrafa del maestro Guerrero 
co personalizan muchos de los temas. Además, conviene destacar el empleo del arpa, frecuentemente asociado a elementos de naturaleza fantástica. Por su parte, el piano realiza intervenciones esporádicas, reforzando la plantilla orquestal. Por último, cabe destacar la utilización de un timbre un tanto peculiar, como es el silbido humano — generalmente asociado a ambientes pastoriles, que van bien con el contexto de La Mancha, la cabrita peregrina y el "zagal" Garbancito, etc.-, con una intencionalidad expresiva.

\section{Análisis temático y formal}

Los temas musicales más importantes de Garbancito de la Mancha son: el [Tema de Peregrina] ${ }^{84}$, el "Número [musical] de los gusanos", la "Canción del trabajo", el [Tema de los tres pillos], la "Canción de «los Chopos»" y la "Marcha de la espada".

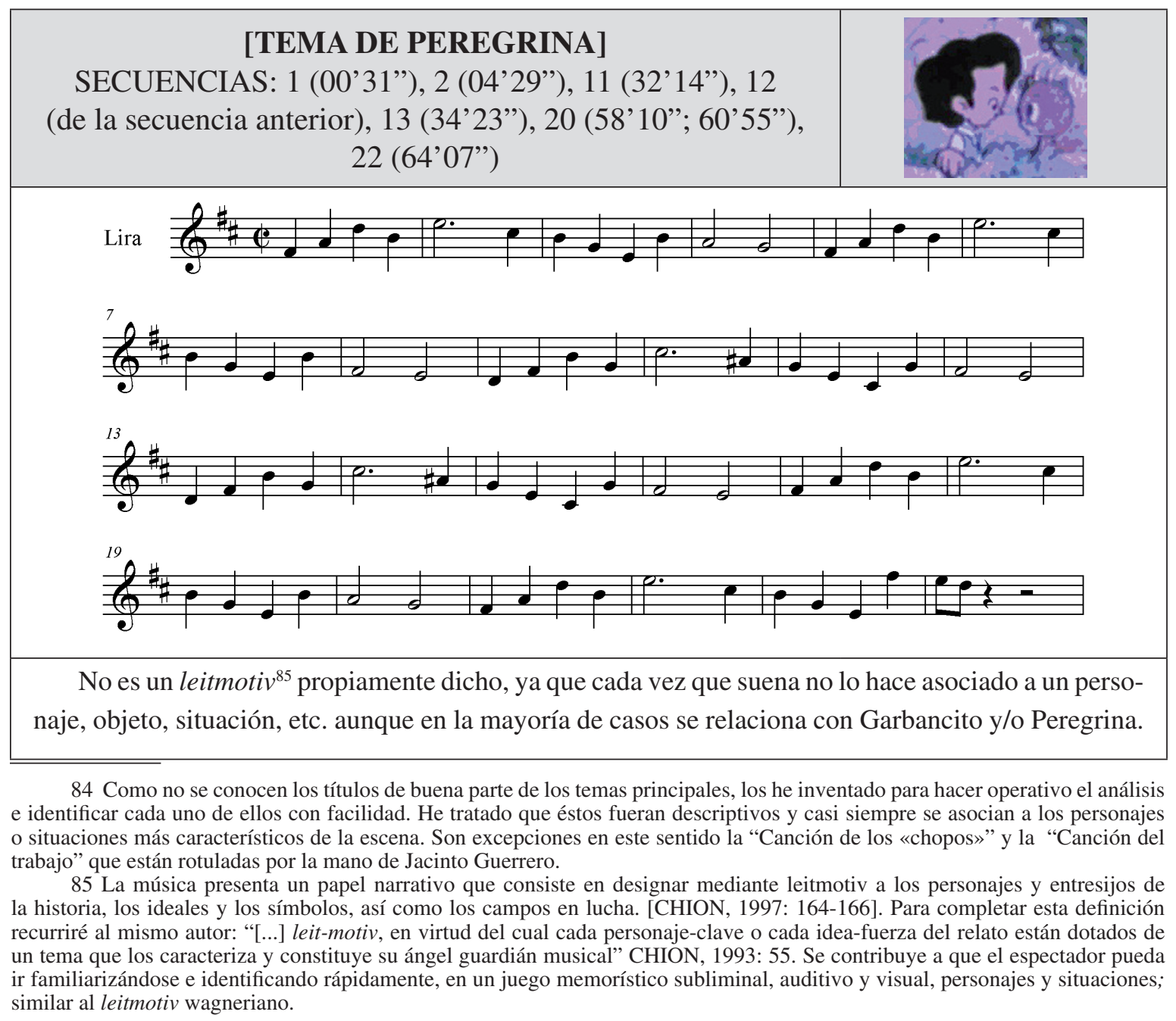


La música recuerda el sonido de un organillo de feria: tema recurrente (se repite varias veces). Posiblemente, quiera simular la esfera del reloj que aparece al inicio de la película, cuando se presentan los personajes: se constata, por tanto, una "convergencia física" ${ }^{86}$ con el movimiento de la cámara, que gira siguiendo el sentido de las agujas del reloj.

La música es alegre y desenfadada. Estos efectos se consiguen mediante la utilización del modo mayor y una orquestación y articulación concretas (staccato de la percusión y pizzicato de las cuerdas) ${ }^{87}$.

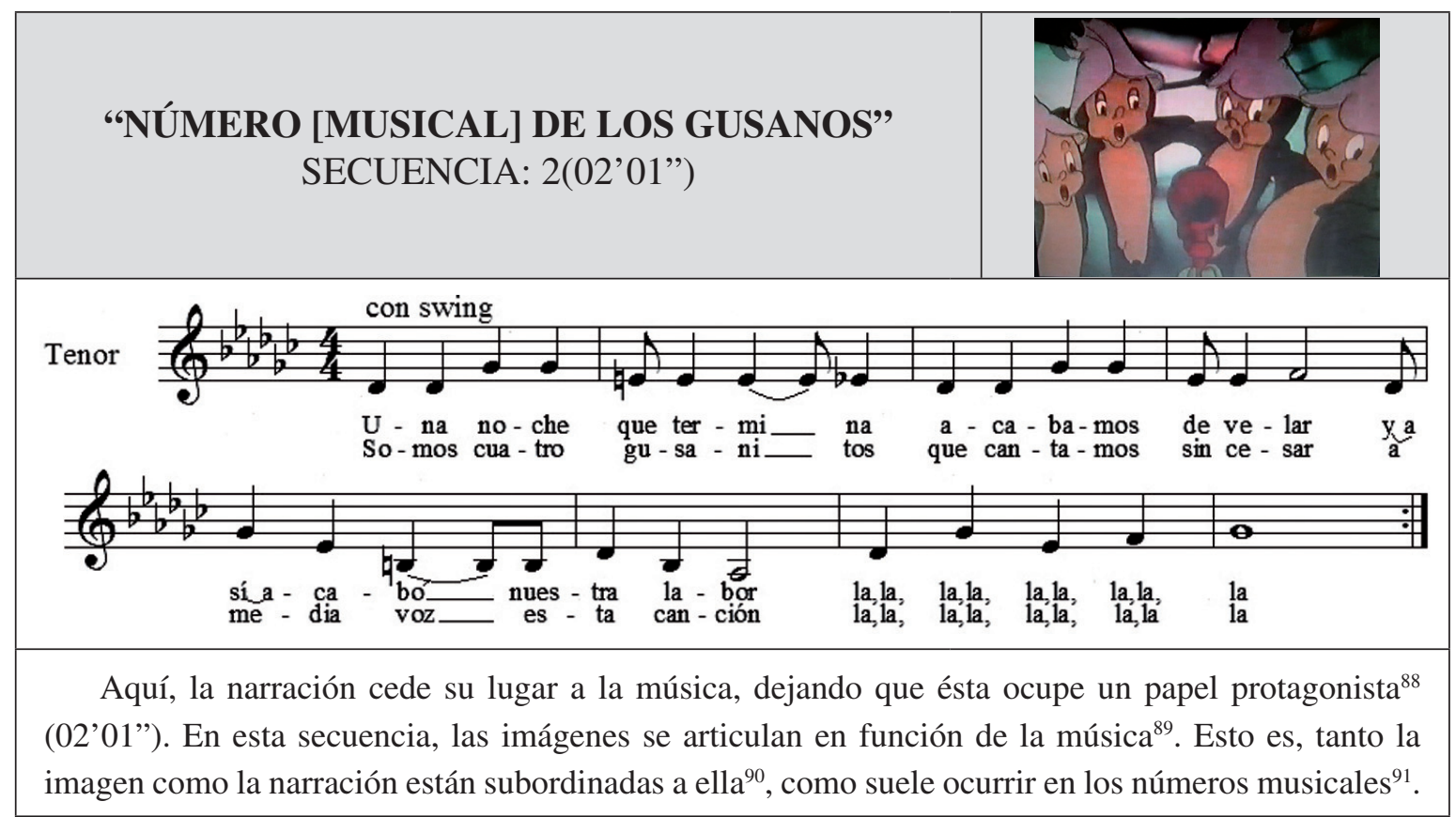

86 LLUÍS I FALCÓ, nº 21 (Barcelona, 1995b): 169-186.

87 R. Beltrán habla de la utilización de la orquestación, tesituras, modalidad, etc. para conseguir una composición para la imagen con funciones expresivas: "Los fragmentos musicales en los que predomina una tesitura aguda y tonalidad mayor nos producen la sensación de claridad. Por ello lo relacionamos con el estado anímico de regocijo, sinceridad, diversión, admiración, etc., o sea, expresiones agradables. (Luz. Día). [...]El movimiento rápido produce excitación y el movimiento lento reposo o calma. Por supuesto, ningún estado de ánimo, triste o alegre, superficial o profundo, juguetón o soñador, burlón o enfermizo, puede ser evocado por características de sonido aisladas, dependerá más bien, en general, del giro melódico, de la armonía, del ritmo, del movimiento, de los matices dinámicos, es decir del conjunto de la construcción del trozo musical." OLARTE MARTíNEZ, 2001, Vol. I (Madrid, 2001): 751-752.

88 Matilde Olarte se pregunta: “[...] el por qué de la utilización excesiva de canciones de pop, rock o jazz, cuya inclusión en la película no responde a necesidades estructurales del guión; [...]".OLARTE MARTÍNEZ, 2001, Vol. I (Madrid, 2001$): 746$.

89 Recuérdese de nuevo que, en Garbancito de la Mancha, primero se realizaron los dibujos y después se compuso la banda sonora, adaptando la música a la imagen, con excepción del número musical de los gusanos, “[...] lo cual lleva consigo una mayor dificultad". MANZANERA, 1992: 28

90 "Pero como la escena implique un ajuste exacto entre música y animación, por ejemplo en un baile, entonces convendrá dar la composición totalmente acabada al animador. Las escenas de baile o las canciones suelen ser muy complicadas y exigen oír lo que después se pondrá en movimiento" DELGADO, 2000: 67.

91 LLUÍS I FALCÓ, nº 21 (Barcelona, 1995b): 169-186. 


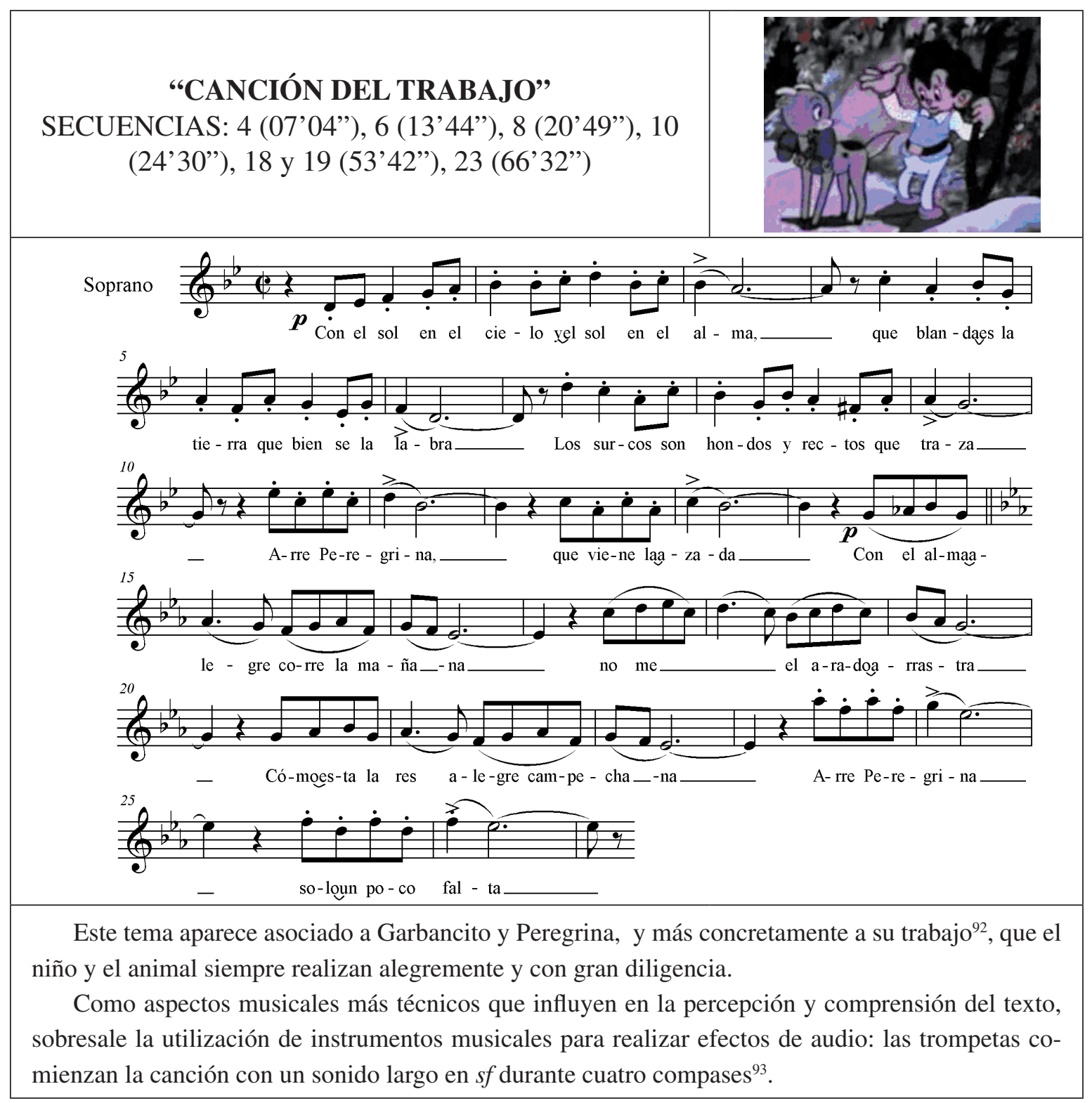

92 "De gran importancia son los cantos que se adscriben a los trabajos y faenas. Como en cualquier lugar del mundo, en los pueblos españoles las gentes trabajadoras acompañaban frecuentemente con canciones sus ocupaciones y oficios. Aparecen en las principales labores campesinas, pero a la vez en las más secundarias y en las de los oficios y profesiones más comunes en los medios aldeanos, rurales y marítimos. Las hay para cavar, desterronar, arar y sembrar las tierras; escardar y escavanar los sembrados, de siega, trilla, venteo, y por fin, acarreo de los granos a las paneras; (...)" NETTL, 1985: 127. Y se convierten en un cliché cinematográfico en las películas de animación. Recordemos como ejemplo la famosa canción de Blancanieves y los siete enanitos (1937) cantada por los siete enanitos de vuelta a casa después del trabajo, "Heigh-ho!". Aunque en este caso, la canción no es entonada por los personajes, sino que se trata de música sin justificación en pantalla (no diegética).

93 La partitura recoge una acotación autógrafa del compositor: "imitando el balido de la cabrita", efecto que se puede oír perfectamente en la película. 


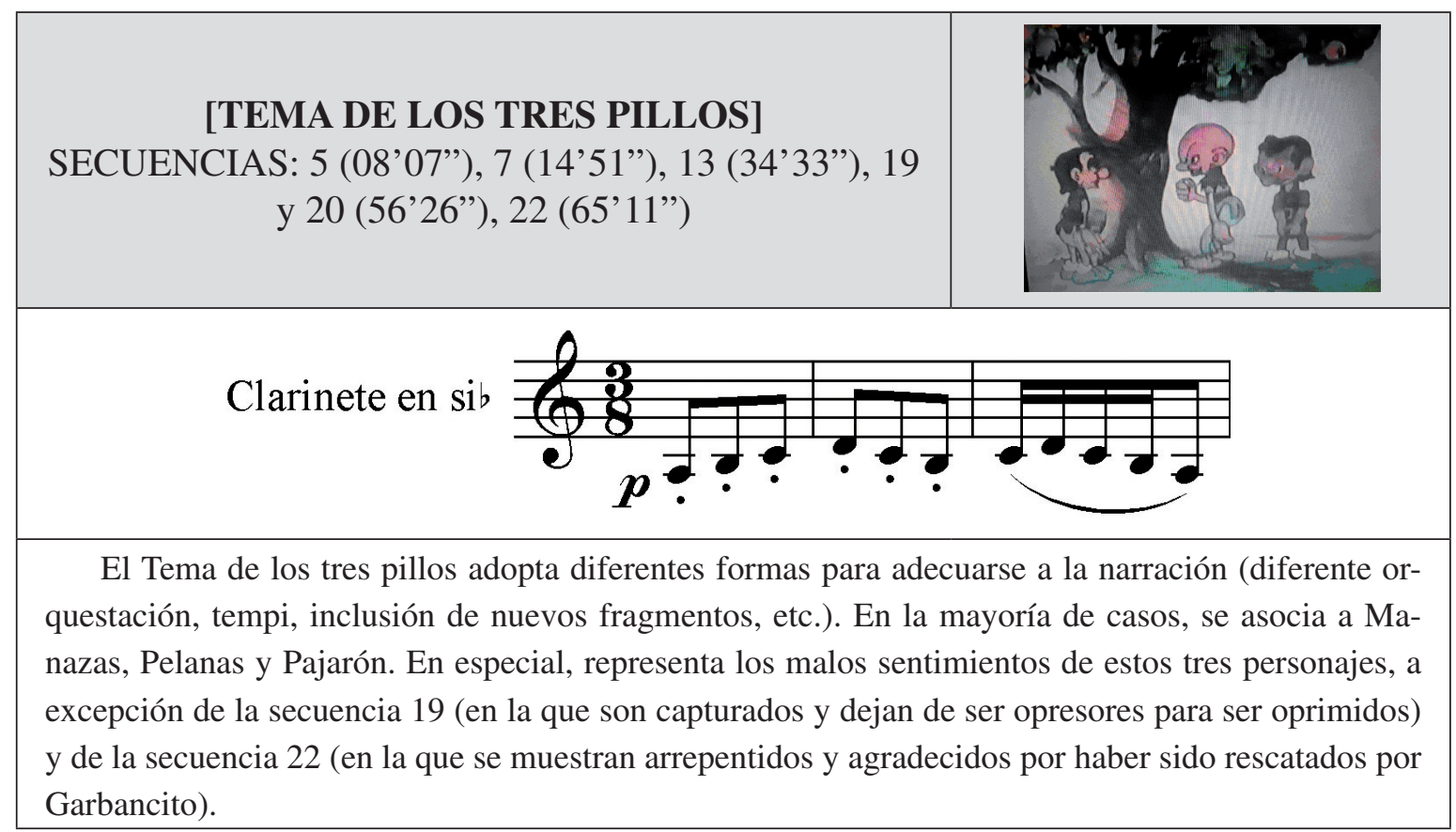

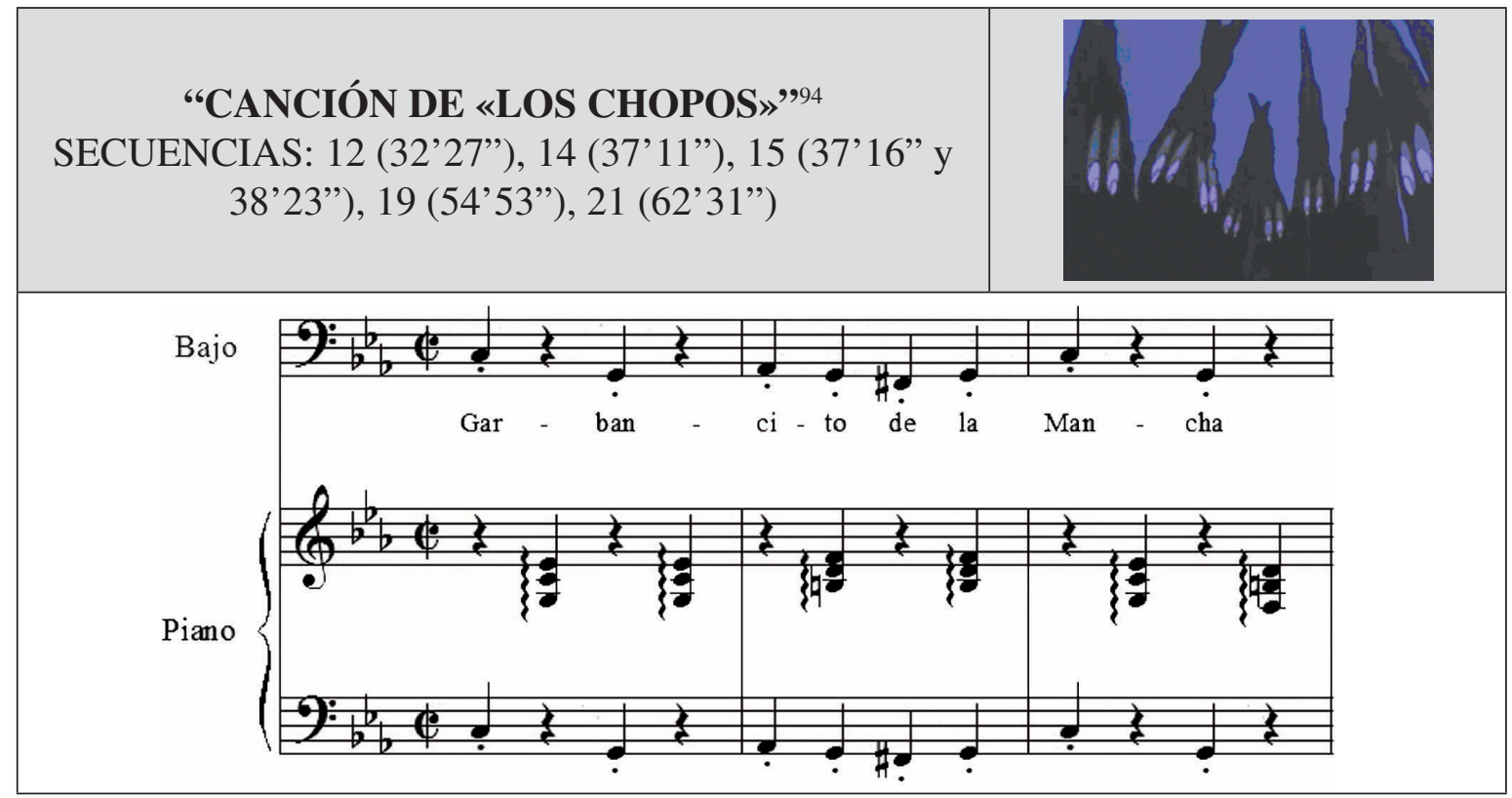

94 Este tema es uno de los que se incluyen en las ediciones discográficas de los cantables, editadas en Barcelona en el año 1945 por la Compañía del Gramófono Odeón. Concretamente se corresponde con la cara A del disco 1, acompañado en su cara B por "La rata torera". Aunque en el disco el tema que nos ocupa se titula de otra manera ("Danza de los cipreses"), yo he decidido conservar el nombre que le otorga J. Guerrero en su partitura. 
La narración cede su lugar a la música, dejando que ocupe un papel protagonista. Se trata de un número musical y, al igual que en el "Número [musical] de los gusanos", se verá claramente que las imágenes se articulan en función de música.

Si se escucha atentamente la letra de la canción, se entenderá que los chopos tratan de darle ánimo a Garbancito e infundirle valor. Pero además, adelanta algunos acontecimientos: "cantará mañana gloria, gloria" o "Presto pondrás en tierra a tu rival, a tu rival / Pronto te aclamarán por vencedor". Así que se puede afirmar que los árboles vaticinan la victoria de Garbancito sobre el gigante.

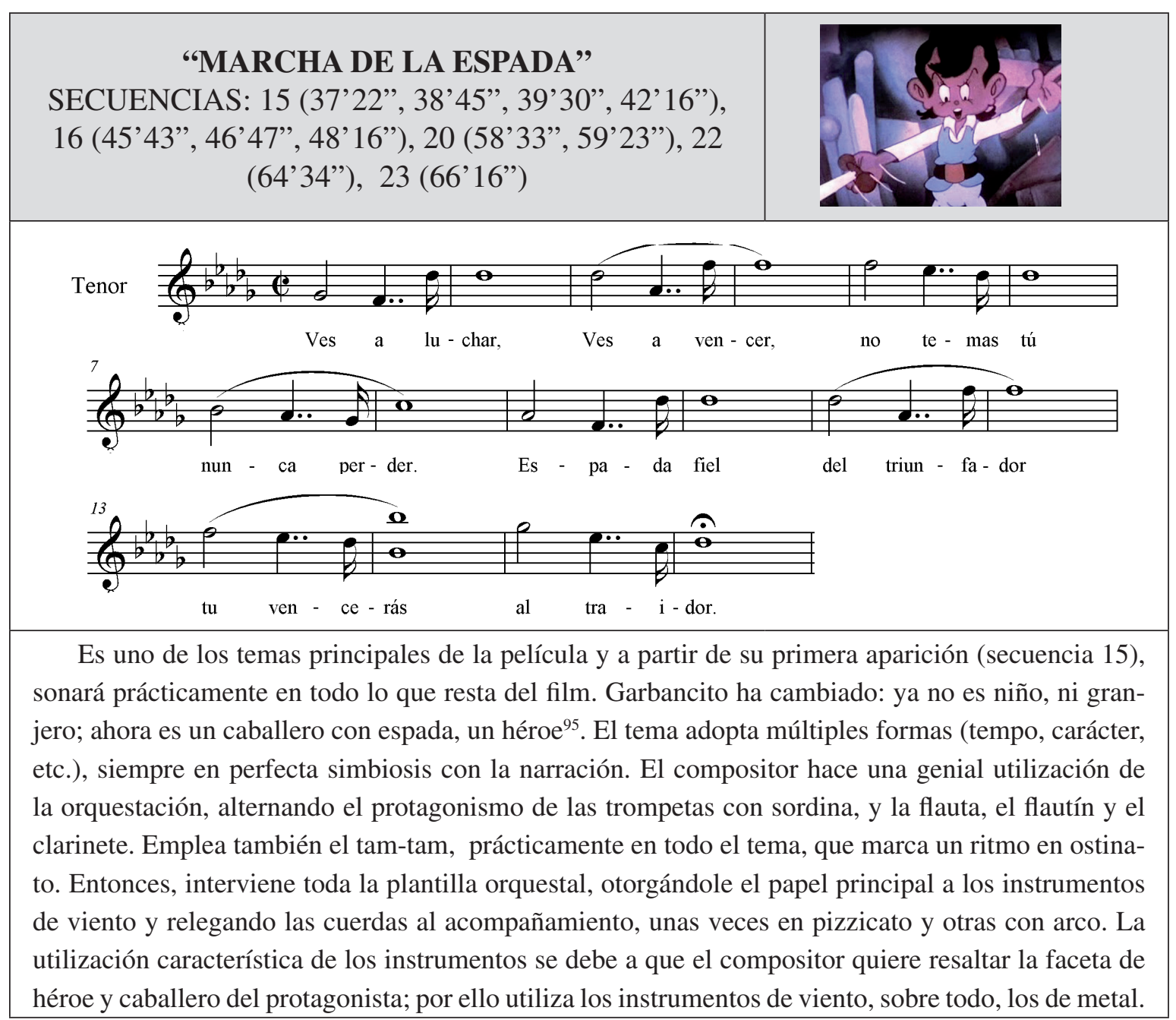

95 Dicho tema viene a representar este cambio en el personaje (proceso psicológico) [esta función psicológica que realiza la música en relación con la imagen no es novedosa sino que ya está presente en las óperas. Un claro ejemplo de ello son las óperas de Mozart, Le nozze di Figaro, Cosí fan tutte, e incluso Don Giovanni]. Recuérdese que una de las funciones narrativas de la música que presenta M. Gértrudix en su libro respecto a los personajes, es la "prosopopeya sonora", que define como aquella que "enfa- 
Los temas expuestos anteriormente se emplean asiduamente a lo largo de la película, a excepción del "Número [musical] de los gusanos", que excepcionalmente fue realizado por el joven Joaquín Bisbe (en una pieza de corte jazzístico, al estilo de Hollywood) y que únicamente aparece en la secuencia 2.

Esta tipología de temática musical es trascendente, por el número de ocasiones en que se presenta. Pero, sobre todo, por estar asociada (a modo de leitmotiv) a los personajes principales ([Tema de Peregrina], [Tema de los tres pillos], a diversos hechos narrativos fundamentales ("Marcha de la espada", "Canción del trabajo", "Canción de «los chopos»") o por el contrario, a momentos excepcionales ("Número [musical] de los gusanos").

En cuanto a la tipología musical, existe una gran variedad: números musicales, la canción, el pasodoble, etc. Podríamos decir, por tanto, que la banda sonora de esta película se adscribe a tres grandes formatos: los números musicales, la canción y la "música culta habitual en un film".

Dos números musicales en el transcurso del largometraje, suponen unas de las secuencias más logradas de todo el film: el "Número [musical] de los gusanos" (sec. 2) y la "Canción de «los chopos»" (sec. 12).

Ambos fragmentos forman parte del conjunto de temas principales de la película. En éstos, interviene el Cuarteto Vocal "Orpheus", aportando un estilo musical enraizado en el jazz y el musical americano. Lo cual, constituye una clara evidencia de la influencia del cine de animación americano, en especial el realizado por Walt Disney.

La canción también ocupa un lugar relevante. Jacinto Guerrero le otorga considerable importancia: se cuentan tres más, aparte de los números musicales: el "Tema de Peregrina" (sec. 2: segunda aparición); la "Canción del trabajo" (sec. 4: primera aparición); y la "Marcha de la espada" (sec. 15: primera aparición).

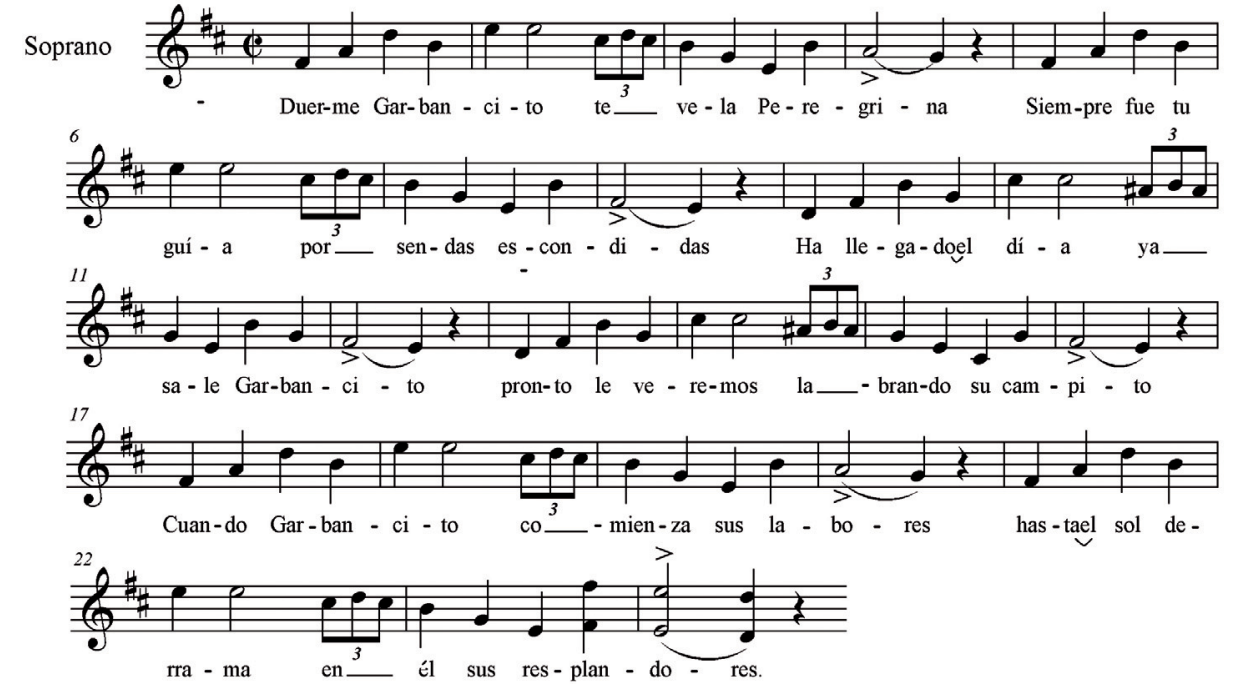

Figura 19. [Tema de Peregrina] (04'29"). Segunda aparición, en forma de canción

tiza y anuncia su disposición en la acción, los rasgos de actuación y sus transformaciones" [GÉRTRUDIX BARRIO, 2003: 173]. Así, se produce una nueva caracterización psicológica del personaje a través de la música: "La música nos puede mostrar muy eficazmente, casi por inmersión, esos procesos mentales mediante la utilización de elementos formales más o menos primarios y directos, combinados a su vez con estructuras más o menos complejas y elaboradas” NIETO, 1996: 102. 
Las dos primeras canciones citadas (es decir, el [Tema de Peregrina] y la "Canción del trabajo") las interpreta la Soprano Pepita Russell, mientras que el "Marcha de la espada", para Tenor, lo canta Cayetano Renom. Las tres forman parte de los temas señalados como principales, aunque sólo se presentan como canción en una de sus apariciones. La relevancia que se les otorga puede obedecer a aspectos tales como: la película va dirigida, principalmente, a un público infantil, por lo que la canción es el género musical más cercano; motivos comerciales; influencia de la tradición norteamericana ${ }^{96}$; influencia de la zarzuela e interés personal del compositor (y de quienes le contrataron al efecto) por este género ${ }^{97}$.

A pesar de la trascendencia de ambos, canciones y números musicales, el autor establece unos criterios concisos a la hora de delimitar tanto el número de apariciones como su situación. Todo ello en aras de contribuir a la continuidad del discurso narrativo: se lleva a cabo un uso muy acertado de las canciones y números musicales ${ }^{98}$. Posiblemente, este hecho esté directamente relacionado con la dilatada experiencia de J. Guerrero en el campo de la zarzuela ${ }^{99}$.

El tercer y último formato, es el de la "música culta habitual en un film" que ocupa la mayor parte del metraje y que, en realidad, engloba el resto de manifestaciones musicales. Hay que destacar la presencia del pasodoble - típico español, como Garbancito de la Mancha-, en dos ocasiones: el "Pasodoble de la granja" (sec. 5) y "La rata torera" (sec. 6).

La inclusión de estos dos temas está directamente ligada a la exaltación del espíritu patriótico español, pues el pasodoble es una de las danzas sociales nacionales más características de España.

Ambos presentan las características y estructura necesarias para adaptase perfectamente a la narración. El "Pasodoble de la granja" (08'56") es un pasodoble-marcha ${ }^{100}$ pues sus características musicales ${ }^{101}$ se adaptan perfectamente al apresurado discurrir de los animales que van en ayuda de su compañero, un

96 M. Chion se hace la siguiente pregunta: “¿Por qué razón, en el largometraje de dibujos animados, desde Blancanieves y los siete enanitos (Snow White and the seven dwarf, 1937) de Walt Disney hasta El rey león (The lion king, 1994), se da esta tradición inamovible, del número cantado y bailado? El filme de animación, y el margen de irrealidad que se le autoriza, así como sus infinitas posibilidades de deformación plástica, dan a los realizadores toda la libertad para «contrapuntuar» una canción con detalles visuales y juegos escénicos paralelos, placenteros precisamente en la medida en que son independientes del texto y del contenido cantado. [...] la canción humaniza al personaje (ya que le presta palabra y música) [...] [ésta,] otorga a las películas una especie de universalidad". CHION, 1997: 292.

97 "Su interés por las melodías tradicionales manchegas es un hecho demostrado; ya en 1951, último año de su vida, aparece un epílogo suyo al Cancionero musical popular manchego de Pedro Echevarría Bravo elogiando su importante labor de recolección de canciones del repertorio oral, e incluso Carabias comenta que «la música popular que oía cantar a los mozos y mozas de los pueblos le encantaba, y siempre que podía hacía que se la repitieran para escribirla en un trozo de papel y estudiarla después, sacando de ella infinitas sugestiones»". CORTIZO, 2000, vol. 6: 46.

98 "[...] lo cantado y lo hablado han de caminar en perfecta simbiosis, de suerte que el espectador no advierta distinciones. La obra ha de ser una unidad, y cualquier sensación de que todo se detiene para que, por ejemplo, la gallinita se marque el número musical, aburrirá a las mismas gallinas". DELGADO, 2000, 50.

99 "Guerrero consiguió convertirse en uno de los creadores de más éxito, y algunos temas sueltos de sus obras han pasado

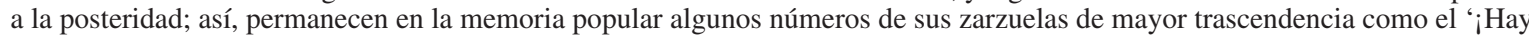
que ver!' de La montería, 'Amigos siempre amigos' de Los gavilanes, 'Fiel espada triunfadora', el coro de lagarteranas y la romanza 'Bella enamorada' de El huésped del sevillano o el coro de espigadoras y 'La canción del sembrador' de La rosa del azafrán. Éstos [...] se han vertebrado dentro de la lírica popular y permanecen" CORTIZO, 2000, vol. 6: 51.

100 Se pueden distinguir varios tipos de pasodoble. Además del pasodoble-marcha existen pasodobles toreros, pasodobles de concierto, canción-pasodoble, pasodobles festivos, pasodobles regionales, pasodobles estudiantiles, etc.

101 En el pasodoble-marcha el ritmo debe ser continuo y, los giros melódicos y armónicos, más sencillos que en el resto de sus modalidades, para así facilitar su ejecución mientras se va desfilando. 
desfile en toda regla. En cambio, el pasodoble "La rata torera" (11'39") acompaña la pelea entre el felino y el ratón a modo de "corrida de toros". Así que el compositor encontró una fácil y adecuada solución para crear la música de este fragmento, de reminiscencias netamente españolas: un pasodoble torero ${ }^{102}$.

Los precedentes de esta utilización del pasodoble para situar la acción en el mundo taurino son muy frecuentes en el teatro lírico ${ }^{103}$ y existen algunos ejemplos en óperas ${ }^{104}$.

Aunque no es la forma musical de los temas más relevantes de la película, el vals está también presente en numerosas ocasiones, siempre asociado a momentos líricos o cómicos: el [Vals de la mosca] (sec. 3); el [Tema del hada] (sec. 14), el [Vals del trapecista] (sec. 15), la [Música del agua] (sec. 15), y el [Vals del lago] (sec. 21). Una utilización sustancialmente diferente lo constituye el [Vals del lago] (63'13”) pues se corresponde con el momento posterior a la muerte de Tía Pelocha, la bruja. Es un vals gracioso, con un tempo lento que atempera dicha muerte ${ }^{105}$.

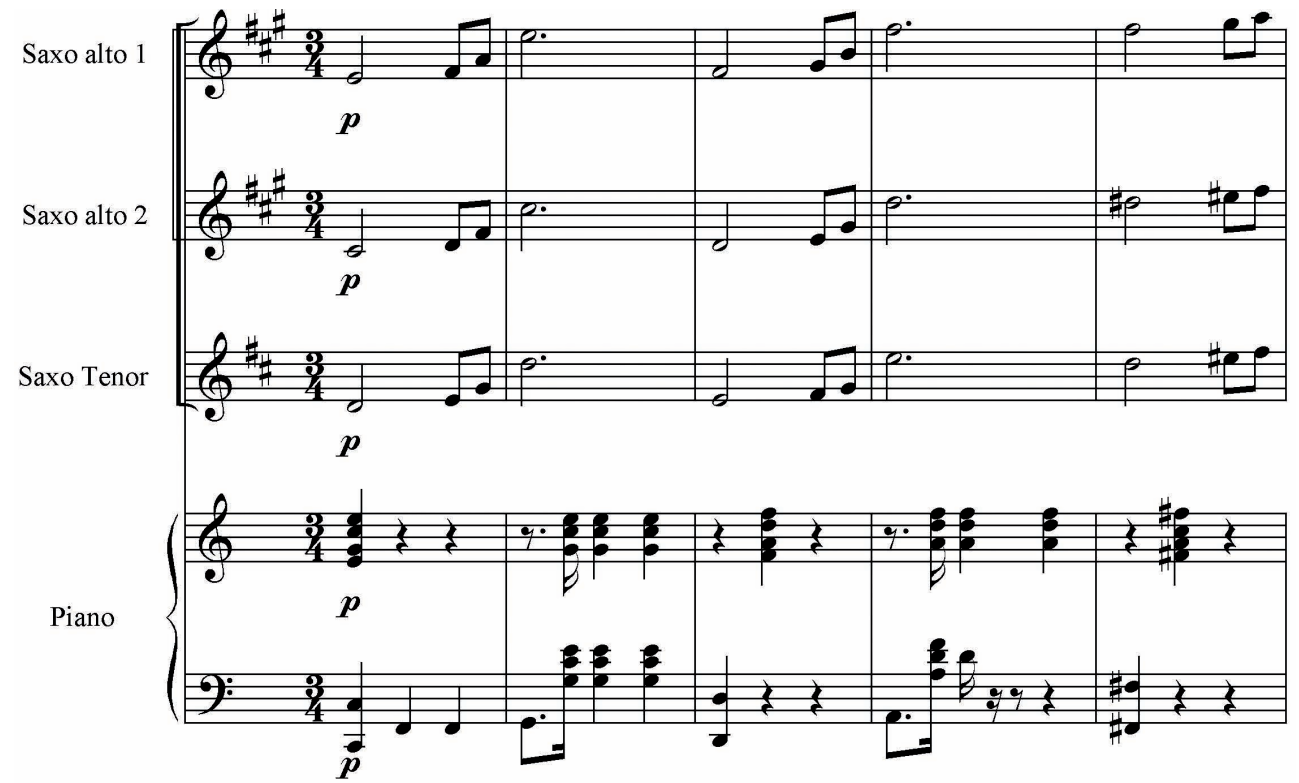

Figura 20. Inicio del [Vals de la mosca] (06’09”)

102 Como es bien sabido, el pasodoble es ingrediente indispensable en cualquier corrida de toros. La música está presente desde el paseíllo inicial, al cambio de suerte, etc., e incluso, supone un premio a la buena "faena" del torero.

103 Algunos ejemplos que lo incluyen para situar la acción de la obra en el mundo taurino son Pan y Toros (1864) o El Barberillo de Lavapiés (1874) de Francisco Asenjo Barbieri (*1823; †1894), La Gran Vía (1886) de Federico Chueca (*1846; $\dagger 1908)$ y Joaquín Valverde Durán $(* 1846 ; \dagger 1910)$, Agua, azucarillos y aguardiente (1897) también de F. Chueca; ya en pleno siglo xx, en La del Manojo de Rosas (1934) y Don Manolito (1943), de Pablo Sorozábal (*1897; †1988); o Molinos de Viento (1911) y El niño judío (1918), de Pablo Luna Carné $(* 1879 ; \dagger 1942)$. También incluyen pasodobles en sus zarzuelas, el valenciano Ruperto Chapí (*1851; †1909) en El Tambor de Granaderos (1896) o El Puñado de Rosas (1902), el catalán Amadeo Vives Roig (*1871; $† 1932)$, en La Generala (1912), o el madrileño Federico Moreno Torroba (*1891; †1982) en La Chulapona (1934).

104 Los ejemplos más populares son la Canción del “Toreador” de Carmen (1875) de George Bizet (*1838; †1875), cuyo último acto se desarrolla en la Plaza de Toros de la Maestranza de Sevilla; o El Gato Montés (1916), del valenciano Manuel Penella Moreno (*1880; †1939), con su popular pasodoble.

105 Una vez más, la música le quita dramatismo a la narración (film infantil). 
También destaca el tema de las “«Seguidillas» ${ }^{106}$ de la victoria” (65’34”), sec. 23 (la última secuencia), en la que el compositor elige un género muy español.

Claramente, este tema está influenciado por la experiencia del maestro Guerrero en el campo de la zarzuela. La intención es clara: buscar un tema que reúna las características para cubrir las necesidades de la narración: melodía alegre que refuerce la alegría del momento; tema que represente el triunfo del bien sobre el mal y reconocimiento de las buenas acciones; y exaltación del espíritu nacional. Qué mejor fragmento para este final que unas seguidillas que encajan perfectamente con este perfil.

\section{Análisis de la música en relación con la imagen (“contrato audiovisual”).}

\section{Características $^{107}$}

1) Música diegética - música no diegética ${ }^{108}$. La mayoría de la música de la película es música no diegética, ya que no encontramos ninguna justificación en pantalla mientras se escucha. La música diegética se da en:

- El "Número [musical] de los gusanos" (sec. 2): la música encuentra una clara justificación en la imagen y en la narración ya que son los gusanos los que cantan y el resto de animales quienes crean la música (música diegética).

- El [Tema de la plaza] (sec. 9): se encuentra una justificación en pantalla para este fragmento aunque no se puede tomar aquí el término diegético como absoluto ${ }^{109}$ ya que aunque en la imagen aparece un músico tocando una especie de chirimía, en realidad participan más instrumentos.

- La "Canción de los «chopos»" (sec. 12): son los árboles los que le cantan a Garbancito. Un poco más difícil de justificar como música diegética es la música que acompaña el canto de los árboles, ya que en ningún momento aparecen en pantalla los instrumentos que la producen.

106 Danza que se baila en pareja, muy extendida por España, al menos desde los siglos XVII y XVIII, [son especialmente típicas/famosas las "seguidillas manchegas", y aquí se trata precisamente de Garbancito "de la Mancha"...], acompañada a la guitarra, y en compás ternario moderadamente rápido.

107 Para el análisis de características y funciones de la música de esta película, se ha tomado como referencia el texto de ROMÁN, 2009, entre otros.

108 La música diegética es aquella que "corresponde de forma natural a la historia narrada, o dicho de otro modo, la que tiene un origen justificado en la imagen, una fuente que la produce. Es precisamente así, source music (música de «fuente») como se la denomina en Estados Unidos. Resulta por lo tanto evidente que músicos, orquestas o cantantes que aparezcan en imagen, así como radios, tocadiscos, cassettes o cualquier otro artilugio capaz de emitir música, y que forme parte del atrezzo de una secuencia, producirá lo que llamamos música diegética" [NIETO, 1996: 37, 38]. En oposición a ésta, se utiliza el término de música no diegética. Además, se encuentran muchas otras denominaciones como la de M. Chion, que utiliza el término "música de pantalla" en oposición a "música de fondo" [CHION, 1997: 193]. M. Gértrudix habla de "música extradiegética" [GÉRTRUDIX BARRIO, 2003: 170] y recoge otras denominaciones de algunos autores: "música viva" [PADROL y VALLS, 1990], "música objetiva" [BELTRÁN MONER, 1984] para música diegética y "música transicional, integrada o decorativa [PADROL y VALLS, 1990], "música subjetiva" [MONER, 1984] para música no diegética. M. Olarte recoge una denominación más para música diegética o de 'background' y remite al lector a JONES y JOLLIFFE, 2000: 196 donde se recogen "las nuevas nomenclaturas para diegética o accidental e incidental" [OLARTE MARTÍNEZ, 2001, Vol. I (Madrid, 2001): 747]. En resumen, todos tratan de distinguir entre la música que se puede justificar con lo que ocurre en la acción y la que no.

109 "Vamos a ver lo sutil y fácil de traspasar que es la línea que la separa de la no-diegética. O lo que es lo mismo, lo fácilmente que la música puede cambiar su condición de diegética a no-diegética en unos segundos. [...] sin que el espectador lo haya percibido, la música ha mutado su condición, mediante un simple cambio de color y del volumen que identificaban la fuente que la producía [...]" [NIETO, 1996: 128 y 129]. 
- La [Marcha de la espada] (sec. 23) en su última aparición: se halla una justificación en pantalla para este tema ya que a los pocos segundos de que comience a sonar, se nos presenta en la imagen un grupo de músicos que son posiblemente la banda del pueblo y que tocan esta música para vitorear al héroe.

2) Valor añadido ${ }^{110}$ : "convergencia / divergencia física, anímica y cultural" ${ }^{111}$. Suele ser frecuente la convergencia en los tres aspectos, aunque se encuentran algunas excepciones, sobre todo, en lo que respecta a la dimensión cultural (influencia del jazz):

- Convergencia física. Un buen ejemplo lo constituye la sec. 6: la primera parte es tranquila; la segunda, inquieta y movida; y la tercera y última, distendida y alegre. También está muy presente en la $3^{\mathrm{a}}$ escena de la sec. 7, contribuyendo a la sensación de velocidad derivada del [Tema de la persecución] ${ }^{12}$. Esta misma situación se repite en el [Tema de la persecución] de la bruja (sec. 9, $3^{\mathrm{a}}$ escena), en la "Canción de los «chopos»" (sec. 12) y en toda la sec. 15.

- Convergencia anímica. Es más marcada en la "Canción del trabajo" (sec. 4, 8), el [Tema del gigante] (sec. 10) y el [Tema de la tormenta] (sec. 17), entre otros.

- Convergencia cultural. El [Tema de Peregrina] (sec. 2) y la "Canción del trabajo" (sec. 4), son dos claras muestras en las que la influencia de la zarzuela cobra un papel especialmente destacado. También recoge esta función el "La rata torera" (sec. 6) y las seguidillas de la sec. 23.

- Divergencia cultural. Está presente en el "Número [musical] de los gusanos" y en la "Canción de los «chopos»" (en su primera aparición).

3) Original — Cita — Cliché ${ }^{116}$. Toda la música de la película es original. Se pueden encontrar dos momentos en los que se utiliza algún cliché cinematográfico:

- El [Tema de la persecución] que se ha construido sobre el cliché cinematográfico de "música de persecuciones" ${ }^{113}$. El final de esta secuencia está concebido en la estética que aplica el cine mudo en los montajes de sucesos rápidos: la música juega un papel principal y se simplifica al máximo la imagen, siempre centrando la percepción del espectador en el tiempo ${ }^{114}$.

- En el [Vals de la mosca] un redoble de caja acompaña al vuelo de la mosca, directo al interior del huevo. El redoble nos recuerda aquí a un redoble circense que hace referencia a los difíciles números acrobáticos de “iel más difícil todavía!". También podríamos entenderlo como una referencia a un avión militar $^{115}$ (cliché cinematográfico).

110 Vid. CHION, 1997: 232, 233.

111 Términos acuñados por J. Lluís i Falcó para referirse a la música que se utiliza en un momento determinado con la finalidad de transmitir las mismas sensaciones o efectos (convergencia) que las imágenes o bien, lo contrario (divergencia), ya sea desde una perspectiva emocional, física o cultural.

112 Clara influencia de las películas del cine mudo.

113 "La música desempeña igualmente un papel privilegiado en las secuencias de persecución" CHION, 1997: 46.

114 "El cine mudo, sin embargo, ya tenía cierta predilección por los montajes rápidos: observemos, no obstante, que, en este tipo de secuencia, procuraba simplificar la imagen hasta el máximo, es decir, limitaba la percepción espacial y exploratoria, para facilitar la percepción temporal. Esto implicaba una visión altamente estilizada, análoga a un croquis” CHION, $1993: 22$.

115 En el cine, desde su etapa del cine mudo (como desarrollo de efectos sonoros), se han establecido unos clichés en el que el sonido de la caja está asociado a lo militar, la autoridad, o a un momento de tensión expectante (una muerte, un acontecimiento prodigioso...). Pero no son nuevos sino que son herencia centenaria del mundo de la ópera. Entre muchos ejemplos, podemos destacar la silbada "Marcha del coronel Bogey" ("Colonel Bogey March", del compositor Malcom Arnold) de la película El puente sobre el río Kwai (The Bridge on the River Kwai, David Lean, 1952), o la conocida escena de Dumbo (Ben Sharpsteen, 1941), en la que el elefante protagonista tiene que saltar, desde la gran altura de la carpa del circo, hasta un pequeño cubo de agua.

116 "Un cliché musical no es más que una pieza de música compuesta con arreglo a una combinación de códigos que se corresponden exactamente con los de un patrón conocido, razón por la cual su efecto sobre el oyente también se conoce de antemano" NIETO, 1996: 90 
Por lo que se refiere a las citas, en la introducción de "La rata torera" se hace referencia a la música que se toca cuando el toro se dispone a salir a la plaza. Se incluyen así, rasgos típicos de la música española con el fin de darle un carácter español a la banda sonora.

4) Música compuesta después del montaje. Toda la música de la película está compuesta después del montaje, a excepción del "Número [musical] de los gusanos".

5) Integrada en el texto audiovisual. De una forma evidente, toda la música está integrada en el texto audiovisual a excepción de la música de los títulos de crédito.

6) Sigue la estética general - Es contrastante. Toda la música sigue una estética semejante a lo largo del film. Más contrastantes son los dos números musicales que, como he señalado anteriormente, beben de una tradición jazzística.

\section{Funciones}

En cuanto a las principales funciones que cumple la música en Garbancito de la Mancha, se puede afirmar que se dan una serie de rasgos comunes:

- Función estructuradora: proporciona continuidad a la narración. La búsqueda de continuidad es una constante, tanto dentro de las secuencias como entre ellas:

- Dentro de las secuencias: el compositor no hace coincidir el cambio de música con el corte fílmico (sec. 17) o se mantiene la misma, aunque haya gran cantidad de planos ("Número [musical] de los gusanos, sec. 2).

- Entre secuencias: un tema ocupa el final de una y el principio de otra (sec. 1-2, sec. 11-12, sec. 1819-20-21), difuminando la transición. Además, ya he comentado la presencia de temas que se repiten, contribuyendo a esta continuidad.

- Función emocional- efecto anempático: le resta dramatismo a las imágenes. La música realiza esta función en las siguientes secuencias: sec. 10: cuando Kiriki y Chirili lloran desconsoladamente, escuchamos su tema, que suena "convenientemente alegre"; sec. 13: mientras los tres malvados le propinan una paliza a Garbancito, la música continúa inmutable; sec. 19: la conversación suaviza, en gran medida, las amenazas que lanza el gigante hacia la bruja.

- Refuerza la información que nos proporcionan las imágenes y el texto. Prácticamente durante todo el film podemos decir que la música realiza esta función: toda la sec. 1: recuérdese que la música apoya la narración en la introducción, en la presentación de los personajes y en la presentación del gigante; la sec. 10, sobre todo a partir de los temas que afectan a la bruja ([Tema de la persecución de la bruja], [Tema de la huida] y [Tema del cuervo]); la sec. 17: la música del castillo apoya la contextualización que nos proporciona la imagen.

- Función pronominal anticipativa: anticipa la presencia de algún personaje. Determinados

temas están asociados a algunos personajes, y así: el [Tema de Peregrina] a Garbancito y Peregrina; el 
[Tema de las hadas] a las hadas; etc., siempre a partir del instante en que se asume esta relación ${ }^{117}$, suenan antes de que aparezca en la acción el personaje al que están asociados: sec. 6: el [Tema de Peregrina] anticipa la presencia de Garbancito; sec. 13: el [Tema de los tres pillos] nos adelanta la aparición de Pajarón, Manazas y Pelanas; sec. 14: el [Tema del hada] anuncia la aparición del hada (aunque la asociación es menos evidente); sec. 15: la parte B del [Tema del hada] anticipa la aparición de la hermana del hada; sec. 20: el [Tema de la bola] anticipa la intervención de la bruja.

- Función correctora: proporciona verosimilitud a las imágenes. A veces, ya sea de una manera intencionada o por problemas técnicos, la imagen necesita de la ayuda de la música para conseguir la verosimilitud requerida por el espectador: sec. 7: persecución del toro; sec. 13: la paliza; sec. 16: el vuelo; sec. 17: la tormenta; sec. 18: el árbol; sec. 19: el ciclón.

- Potencia algunos efectos. La música puede resaltar algunos efectos, evidenciarlos o, por el contrario, hacerlos menos perceptibles. Algunos ejemplos donde la música los potencia son: sec. 5: la pesca del gallo, el rescate de éste y el incidente posterior; sec. 6: la fragua de la espada y los problemas que tiene el niño; sec. 21: la música conduce al momento en que la roca aplasta a la bruja.

- Función cinemática: Mickey-mousing ${ }^{118}$. Aunque en las películas de animación es muy común, en Garbancito de la Mancha se utiliza únicamente en algunas ocasiones, acertadamente: sec. $2,1^{\mathrm{a}}$ y $2^{\mathrm{a}}$ escena: la música puntúa todo aquello que acontece en la imagen; sec. 12: los árboles se mueven al ritmo de la música; sec. 15: fragua de la espada ( $2^{\mathrm{a}}$ escena) y estancia del protagonista en el taller convertido en garbanzo ( $3^{\mathrm{a}}$ escena); sec. 16, $4^{\mathrm{a}}$ escena: tema del leñador.

- Función rítmico-temporal: Temporalización de la imagen ${ }^{119}$. Otra de las principales funciones que lleva a cabo la música en el cine de animación. Animación temporal de la imagen: sec. 2, 15, 17 y 18; linealización temporal de los planos: sec. 2 y 17; vectorización: sec. 2, 5, 10, 14, 15, 18, 20 y 21.

\section{CONCLUSIONES: VALOR ESTÉTICO DE LA COMPOSICIÓN DE J. GUERRERO}

El día siguiente del estreno de la película en Madrid, el 14 de mayo de 1946, aparecieron en la prensa diversas críticas, incluyendo algunas referencias a la música. Así, el crítico de $A B C$, Enrique del Corral escribía que:

"La música del maestro Guerrero es, a nuestro juicio, lo más logrado [...] La realización de A. Moreno y la dirección de J. Mª Blay, desigual, y el sistema Dufaycolor, deficiente"120.

117 La primera vez que la música cumple esta función se produce en la secuencia 6 , y se hará frecuente a partir de la secuencia 13

118 Por "mickey-mousing" (término que alude a los dibujos animados de Walt Disney), o underscoring, se entiende el seguimiento sincronizado de la acción por la música. Vid.: CHION, 1997: 127.

119 "Llamamos temporalización al efecto mediante el cual una cadena sonora, que por definición está casi obligatoriamente inscrita en el tiempo, otorga un tiempo a una imagen que por sí misma no lo conllevaría forzosamente...” CHION, $1997: 212$.

120 MANZANERA, 1992: 32 
En este caso, se resalta la calidad de la creación musical pero no así al resto del film. También fueron muy positivas las críticas vertidas por José de la Cueva en el periódico Informaciones:

"Jacinto Guerrero ha compuesto una partitura toda ella graciosa e inspirada y que sirve muy eficazmente a la imagen" 121 .

Se ve cómo este crítico hace especial hincapié en la perfecta relación que se establece entre música e imagen. En este sentido, expresa también su opinión Luis Gómez Mesa en el diario YA:

"La partitura del maestro Guerrero, jubilosa y grata, realza -y este es el papel de la música en el cine - el juego de las imágenes" 122 .

Una visión más negativa es la que ofrece J. Ma . Candel:

"[Arturo] Moreno tenía sus dudas sobre el Maestro Guerrero, porque consideraba que aunque era un gran compositor, el tipo de música de zarzuela en que estaba especializado no era el más adecuado para una película de dibujos. Pero finalmente los productores impusieron su criterio en base a la comercialidad del nombre. La única concesión que Moreno obtuvo, en el aspecto musical, fue la introducción de una canción de Joaquín Bisbe: la graciosa melodía "hot" de los gusanitos, que por cierto era una de las mejores de la película" 123 .

Puede verse cómo se minusvaloraba para este producto cinematográfico la composición de J. Guerrero, ya que, por ser un consagrado compositor de zarzuelas, se le creía incapaz de crear una partitura que respondiera a las necesidades de la animación. En cambio, se magnificaba la canción creada por Joaquín Bisbe, "Número [musical] de los gusanos" ${ }^{124}$.

Los dos números musicales, especialmente el de los gusanos, son de una calidad y acierto innegables, lo cual no debe condicionar la valoración positiva del resto de la composición. Hay que considerar que, como afirma Enrique del Corral en su ya citada crítica en $A B C$ :

"La canción central y el coro de los cipreses, aparte de otros compases, responden por entero al clima del film y a la modalidad de dibujos animados según los cánones norteamericanos"125.

El tratamiento de estas secuencias, pues, denota una marcada y evidente influencia de la estética americana, también en la música (influencia que no afecta únicamente a la música de cine, sino a todas las manifestaciones musicales del momento, zarzuela, radio, etc.). Dicha influencia no será tan clara en el resto de la partitura del maestro Guerrero. Quizás sea éste el motivo por el que no se valora suficientemente la composición del maestro Guerrero.

121 Ibíd.: 33

122 Ibíd.: 34.

123 CANDEL CRESPO, 1993: 47.

124 M. Manzanera aporta una opinión similar. MANZANERA, 1992: 28.

125 Ibíd.: 32. 
Estos juicios desfavorables carecían de fundamento, por cuanto el propio compositor, como de hecho demostró con su trabajo en el film, tenía una visión muy clara de las necesidades que demandaba el cine por lo que se refiere a la música, como se desprende de las siguientes afirmaciones:

"Es necesario que el compositor de cine se dé cuenta de que hay que crear música especial para el séptimo arte. La medida, la armonización y la instrumentación tienen que ser especialmente hechas y distintas a las que hacemos para el teatro o para el concierto. El micrófono no exige timbres muy especiales. De las cosas más difíciles de hacer es la música de fondo, unas veces para no tapar los diálogos y otras para dar impresiones dramáticas o cómicas como exige el asunto. Es un trabajo muy penoso. Yo he gastado más vista en esta película que en hacer seis zarzuelas del tipo Los Gavilanes" ${ }^{26}$.

Se puede comprobar cómo establece una perfecta distinción entre la música compuesta para el cine y la creada para el teatro o para el concierto, a la que estaban habituados tanto él como la sociedad de su tiempo. Todavía se podría ir más allá, pues Jacinto Guerrero era consciente de las particularidades que presenta la música en el cine de animación e hizo un gran esfuerzo de síntesis y adecuación al nuevo lenguaje:

"La principal característica de esta música (decía el Maestro Guerrero en una entrevista de la época) es la variedad de ritmos que la animan. Por eso mi labor ha sido más ardua que la de poner música a una zarzuela o a una película interpretada por personajes vivientes. En estas cintas de dibujos es menester una enorme diversidad de temas, pues todos ellos pasan raudamente ante el espectador. Por otra parte es menester una expresión muy grande en cada motivo musical, y también un cuidado muy meticuloso en la instrumentación"127.

Además, no se puede creer que (al menos en el contexto de la música del momento, "de consumo"), un hombre como J. Guerrero, no conocería algunos trabajos para el cine de animación de los compositores americanos que le eran contemporáneos, como Frank Churchill $(* 1901 ; \uparrow 1942)$, Leigh Harline $(* 1907$; $\lceil 1969)$ o Paul J. Smith $(* 1906$; †1985), entre otros; o, en el caso de España, las producciones para animación de Jesús García Leoz (*1904; †1953), Rafael Ferrer Fitó (*1911; †1988), o Juan Durán Alemany (*1896; †1970), entre otros ${ }^{128}$.

Sí es cierto que su música está directamente influenciada por su experiencia en la composición de zarzuelas (no podía ser de otra manera). Aunque se insiste en demonizar este hecho en lugar de entenderlo como una fuente de riqueza e inspiración:

126 Palabras de Guerrero referidas en CANDEL CRESPO, 1993: 47.

127 Nuevas afirmaciones del maestro Guerrero. Ibíd.

128 Evidentemente, si todavía no existía una especialización en la composición para cine (ya se ha explicado que la mayor parte de los compositores que se dedicaron a realizar la música de cine provenían del mundo de la escena), resulta impensable, que la hubiese para el cine de animación. Así, algunos de los compositores que escribieron música para cine, también lo hicieron para el cine de animación, como es el caso de los que se nombran. [Entre los españoles mencionados, se puede citar la participación de García Leoz en Un día de feria (1941), El pelo del diablo y La manzana encantada (1942), o en Una extraña aventura de Jeromito (1943); la colaboración de Durán Alemany en El capitán tormentoso (1942); así como la intervención de Ferrer Fitó en Aventuras de Pulgarcito y Don Cleque va de pesca (1941), Civilón boxeador, Don Cleque detective, Don Cleque marinero y La isla mágica (1942) y Don Cleque de los monos (1943)]. 
"En cuanto a la música del maestro Guerrero es poco adecuada [!] para una película de este género. Puede que el empeño del productor de hacer algo 'muy español', influyera en el ánimo del compositor que le dio un enervante aire de zarzuela" ${ }^{29}$.

Pero no se debe pensar que el crear una partitura para Garbancito de la Mancha con música típicamente española fuera algo inducido, ajeno al compositor. Nada más lejos de la realidad ya que, en una entrevista realizada por A. Luján para la revista Primer Plano, el propio Jacinto Guerrero decía que:

"Si el cine español quiere salir de España ha de llevar a la pantalla las costumbres españolas y su música [...] Nosotros debemos hacer cine con nuestras regiones, con nuestros trajes, con nuestros cuentos y nuestra literatura, con nuestra música y costumbres populares, incluso para que cuando otros hagan películas con temas españoles no hagan españoladas [...]. La españolada, después de todo, no es más que una prueba, aunque deformada, de la pasión que por España sienten ellos. Y volviendo al punto de partida -música y costumbres españolas para que nuestro cine salga fuera-, no ignora usted que nuestras películas comerciales fueron ; Viva Madrid, que es mi pueblo; , en la etapa del cine mudo; Nobleza baturra, Morena clara, La Verbena de la Paloma, Rumbo al Cairo y las recientes, basadas en la literatura auténticamente nuestra, como El escándalo o El clavo" ${ }^{130}$.

La adopción de este criterio no es exclusiva para la música de cine:

"En este sentido, Luis Fenández Ardavín comenta en el prólogo al libro de Josefina Carabias que «una gran parte de la labor artística de Jacinto Guerrero quedará incorporada para siempre en el acervo inmortal de la música popular española. He dicho 'popular' porque ésta fue la característica privativa de su personalidad y de su obra. Jacinto Guerrero era, sobre todo, un hombre popular. Es decir, un hombre del pueblo, que produjo para el pueblo y que para el pueblo vivió»"131.

Para concluir, resulta imprescindible, por tanto, poner de manifiesto la magnífica y pionera labor del compositor Jacinto Guerrero. Supo recopilar con extremado acierto diversos estilos que convergieron perfectamente en la música de Garbancito de la Mancha. Sobre la base de su experiencia en el campo de la escena, desarrolló un lenguaje personal a partir de la asimilación de corrientes recién llegadas por entonces a España. A la esencia del estilo empleado en la zarzuela, incorporó las técnicas que le eran propias del cine de animación norteamericano, los giros melódicos del jazz y el acervo de la música popular española, en un trabajo que, más allá de posicionamientos políticos, requiere el unánime reconocimiento técnico y profesional actuales, y el aplauso de una labor pionera, sobre la que se asentaron las posteriores iniciativas en el terreno de la composición de música para la imagen.

129 MANZANERA, 1992: 28

130 MANZANERA y VIÑAO, 6, (enero-diciembre, 1987): 183-185.

131 CORTIZO, 2000, vol. 6: 51. 


\section{BIBLIOGRAFÍA}

ADORNO, Theodor W. y EISLER, Hanns, Gesammelte Schriften in zwanzing Bänden. 15 Komposition für den Film. Der getreue Korrepetitor, Frankfurt am Main, Suhrkamp, 1976 [traducido como: El cine y la música, Madrid, Fundamentos, 1976].

ALTMAN, Rick, Sound Theory, Sound Practice, New York-London, Routledge, The American Film Institute, 1992.

ARÓSTEGUI PLAZA, José Luis, "La música en los dibujos animados", OLARTE MARTÍNEZ, Matilde (ed.), Reflexiones en torno a la música y la imagen desde la Musicología española, Salamanca, Plaza Universitaria, 2009: 553-563.

BELTRÁN MONER, Rafael, La ambientación musical. Selección, montaje y sonorización, Madrid, Instituto Oficial de Radio y Televisión, 1984.

DE LA ROSA, Emilio, "Cine de animación en España”, BENDAZZI, Giannalberto. Cartoons. 110 años de animación, Madrid, Ocho y medio, 2003: 469-508.

CANDEL CRESPO, José María, Historia del dibujo animado español, Murcia, Filmoteca Nacional de Murcia, 1993.

CASTILLO, A. y AZORÍN, V., "Las revistas técnicas como base documental para la recuperación de un patrimonio olvidado: el caso de las salas de cine españolas”, Informes de la Construcción, 61/515, (julio-septiembre 2009): 35-48.

CHION, Michel, L'audio-vision, París, Nathan, 1990 [traducido como: La audiovisión. Introducción a un análisis conjunto de la imagen y el sonido, Barcelona, Paidós Ibérica, 1993].

CHION, Michel, La musique au cinéma, París, Librairie Arthème Fayard, 1985 [traducido como: La música en el cine, Barcelona, Paidós Ibérica, 1997].

CHION, Michel, Le son, París, Nathal, 1998 [traducido como: El sonido. Música, cine, literatura..., Barcelona, Paidós, 1999].

CORTIZO, M ${ }^{a}$ Encina, "Guerrero Torres, Jacinto", Diccionario de la Música Española e Hispanoamericana, Madrid, SGAE, 2000, vol.6: 44-52.

CRUSELLS, Magí, Directores de cine en Cataluña. De la A a la Z, Barcelona, Universidad de Barcelona, 2008.

DELGADO, Pedro E., El cine de animación, Madrid, Ediciones JC, col. "Imágenes, 28”, 2000.

EL MUNDO DEPORTIVO (s/a), 27.09.1934: 4.

GÉRTRUDIX BARRIO, Manuel, Música y narración en los medios audiovisuales, Madrid, Laberinto Comunicación, 2003.

GOLDMARK, Daniel, Tunes for Toons. Music and the Hollywood Cartoon, Berkeley/Los Angeles/London, University of California Press, 2005.

GOLDMARK, Daniel, y TAYLOR, Yuval (eds.), The Cartoon Music Book. Chicago, Chicago Review Press, 2002.

GONZÁLEZ LAPUENTE, Alberto (ed.), Jacinto Guerrero. De la zarzuela a la revista, Madrid, Fundación Inocencio y Jacinto Guerrero/SGAE, 1995. 
GORBMAN, Claudia, Unheard Melodies. Narrative Film Music, Bloomington, Indiana University Press, 1987.

JONES, Chris y JOLLIFFE, Genevieve, The Guerrilla Filmmakers Handbook. Londres, Continuum, 2000.

LA VANGUARDIA (s/a), 16.03.1929: 19; 22.07.1933: 14; 13.05.1936:13; 08.04.1991: 19.

LLUÍS I FALCÓ, Josep, "Jacinto Guerrero. Un compositor ante, de y para el cine”, GONZÁLEZ LAPUENTE, Alberto (ed.), Jacinto, Guerrero: de la zarzuela a la revista, Madrid, SGAE / Fundación Jacinto e Inocencio Guerrero, 1995a, 51-67.

LLUÍS I FALCÓ, Josep: "Paràmetres per a una anàlisi de la banda sonora musical cinematogràfica", D’Art, n'. 21 (Barcelona, 1995b):169-186.

LUCCI, Gabriele (dir.): Animación. Los diccionarios del cine, Milán, Mondadori Electta, 2005 [traducido por: FuRIó, María José; Barcelona, Electa España, 2005].

MALETÁ COCIÑA, Jorge, "La banda sonora en los dibujos animados: del tópico a la brevedad", OLARTE MARTÍNEZ, Matilde (ed.), Reflexiones en torno a la música y la imagen desde la Musicología española, Salamanca, Plaza Universitaria: 2009, 565-583.

MANZANERA, María, Cine de animación en España: largometrajes 1945-1985, Murcia, Universidad de Murcia, 1992.

MANZANERA, María y VIÑAO, Antonio, "Literatura y cine infantil en la España de la postguerra. Garbancito de la Mancha (1945)", Historia de la Educación. Revista interuniversitaria, 6, (enerodiciembre, 1987):145-146.

MARTÍNEZ BARBUENO, María Luisa, El cine de animación en España (1908-2001), Valladolid, Nancy Ediciones, 2003.

MAULE, Elita, La musica dei cartoni. Viaggio didattico nel tempo e nello spazio con le musique del cinema d'animazione, Bolzano, Edizioni Junior, col. "Quaderni Operativi. Collana dell'Instituto Pedagogico provinziale di Bolzano, 15", 2005.

MONTERDE, José Enrique, "El cine de la autarquía”, TALENS, Jenaro (dir.), Historia del cine español, Madrid, Cátedra, [1995] 2005, vol. 40: 181-238.

MONTIEL, Alejandro, “¿Los cipreses creen en Dios? Acerca de Garbancito de la Mancha (Arturo Moreno, 1945)", Con A de animación, nº 2 (Valencia, 2012):83-88.

NADAL I ROVIRA, Núria, "De Garbancito de la Mancha a Los sueños de Tay-Pi. Una aproximación al cine de animación español producido por Balet y Blay”, Con A de animación, nº 2 (Valencia, 2012): 119-133.

NETTL, Bruno, Música folklórica y tradicional de los continentes occidentales, Madrid, Alianza Música, 1985.

NIETO, José, Música para la imagen. La influencia secreta, Madrid, SGAE, 1996.

OLARTE MARTÍNEZ, Matilde, “¿Existe una frontera en la música aplicada a la imagen como elemento expresivo y estructural?", Campos interdisciplinares de la Musicología. v Congreso de la Sociedad Española de Musicología, SEDEM, Vol. I (Madrid, 2001): 751-752. 
PADROL, Joan y VALLS GORINA, Manuel, Música y cine, Barcelona, Ultramar, 1990.

PEMARTÍN, Julián, Garbancito de la Mancha (Ilustraciones de Arturo Moreno), Madrid, Saturnino Calleja (ed.), 1943 [90 pp., 20 cm.].

PRADA, Juan Manuel de: "Garbancito de La Mancha”, en ABC cultural, 973 (21.11.2010)].

RADIGALES, Jaume, "Creació i muntatge musical en el dibuix animat clàssic", Trípodos XI (2001): 107-122.

ROLDÁN GARROTE, David, Fuentes documentales para el estudio de la música en el cine español de los años 40, Tesis doctoral, Valencia, Universidad Politécnica de Valencia, 2003, 114-115. (Consultado el original, existe también edición en formato digital: Editorial de la Universidad Politécnica de Valencia. Ref. 2004.5206. ISBN: 84-688-6216-9).

ROMAGUERA I RAMIÓ, Joaquim, El jazz y sus espejos, Madrid, Ediciones de la Torre, 2002.

ROMÁN, Alejandro, El lenguaje Musivisual. Semiótica y estética de la música cinematográfica, Madrid, Visión libros, 2008.

SEVILLA LLISTERRI, Gabriel, El modelo cruzada. Música y narratividad en el cine español de los años cuarenta, Madrid, Biblioteca, 2007.

TORRELLA PINEDA, Josep, Rodatges de potsguerra a Barcelona. Un recorregut pels estudis de cinema, Barcelona, Institut del cinema català, col. "Orphea, 2", 1991.

\section{RECURSOS ON-LINE:}

"http://www.mcu.es/bbddpeliculas/buscarDetallePeliculas.do?brscgi_DOCN=000002666\&brscgi_

BCSID=1de603a8\&language=es\&prev_layout=bbddpeliculasResultado\&layout=bbddpeliculas"

[Acceso: 17.06.2005]

"http://www.mcu.es/cine/MC/FE/Documentacion/InspeccionTecnicaHTM/07-InspeccionTecnica-3Parte3.htm" [Acceso: 22.11.10]

"http://bdh.bne.es/bnesearch/Search.do;jsessionid=4AF65CE3CC97E599F71772B23FC35F8F"

Recibido: 01/03/2011

Aceptado: 02/05/2012 